\title{
Ganglioside Biochemistry
}

\author{
Thomas Kolter \\ Program Unit Membrane Biology \& Lipid Biochemistry, LiMES, University of Bonn, Gerhard-Domagk Straße 1, 53121 Bonn, Germany
}

Correspondence should be addressed to Thomas Kolter, tkolter@uni-bonn.de

Received 18 September 2012; Accepted 9 October 2012

Academic Editors: H. Itoh and B. Penke

Copyright (C) 2012 Thomas Kolter. This is an open access article distributed under the Creative Commons Attribution License, which permits unrestricted use, distribution, and reproduction in any medium, provided the original work is properly cited.

Gangliosides are sialic acid-containing glycosphingolipids. They occur especially on the cellular surfaces of neuronal cells, where they form a complex pattern, but are also found in many other cell types. The paper provides a general overview on their structures, occurrence, and metabolism. Key functional, biochemical, and pathobiochemical aspects are summarized.

\section{Introduction}

Together with glycoproteins and glycosaminoglycans, glycosphingolipids (GSLs) contribute to the glycocalyx that covers eukaryotic cell surfaces. Gangliosides are sialic acidcontaining glycosphingolipids and provide a significant part of cell surface glycans on neuronal cells. GSLs are lipids that contain a sphingoid base and one or more sugar residues [1]. Sialic acids (Figure 1) are nine-carbon sugars biosynthetically formed from $N$-acetylmannosamine and phosphoenolpyruvate $[2,3]$. With a mean $\mathrm{p} K_{A}$ value of around 2.6, they are more acidic than the majority of carboxylic acids and negatively charged at most physiological $\mathrm{pH}$ values. The name "ganglioside" was coined by the German biochemist Klenk (1896-1971) and assigned to a group of acidic GSLs that he isolated from ganglion cells $[4,5]$ and from the brains of patients who suffered from the so-called amaurotic idiocy $[6,7]$. Sialic acid was first isolated from submaxillary mucin in 1936 [8]. Its structure was elucidated in the nineteen fifties by different groups and it was found to be identical to that of the $N$-acetylneuraminic acid isolated by Klenk and Faillard. The first structure of a ganglioside was elucidated in 1963 by Kuhn and Wiegandt [9]. In 1962, Svennerholm suggested a nomenclature of brain gangliosides $[10,11]$. The biochemical defects underlying the diseases formerly known as amaurotic idiocy, GM1gangliosidosis [12], Tay-Sachs- [13], and Sandhoff disease [14] were identified by Sandhoff and others in the 1960s.

\section{Structure and Nomenclature}

In their structures, gangliosides combine a glycan and a lipid portion and contribute to both, the cellular lipidome and the glycome/sialome [15]. A great variety of carbohydrate sequences are found within the GSLs [16], including the gangliosides [17]. Although carbohydrate residues of different structure, linkage, and anomeric configuration occur in GSLs, only a limited number of the so-called series with characteristic carbohydrate sequences are found within evolutionary related organisms (Table 1). Within the gangliosides, sialic acids can be attached only to a few of the GSL series, in adult mammals especially to the ganglio series.

Among the sialic acids, $\mathrm{N}$-acetylneuraminic acid is the most frequently found member in humans, but also $N$ glycolylneuraminic acid is abundant in many other species (Figure 1). A total of more than 50 different sialic acids have been described $[18,19]$. They can be $O$-acetylated in positions 4,7 , or 9 [20], but also $N$-deacetylated, $O$ methylated, sulfated, or modified by lactonization [21] (see Figure 8).

The nomenclature of GSLs specifies the glycan part of these lipids. Two ganglioside nomenclature systems are currently in use to assign names to the corresponding structures. Most researches prefer the short-hand nomenclature according to Svennerholm, which was initially based on the migration order of ganglio-series gangliosides in chromatography [10]. Later on, it has been extended to other 


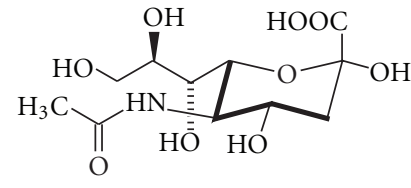

$N$-acetyl- $\alpha$-neuraminic acid (Neu5Ac)

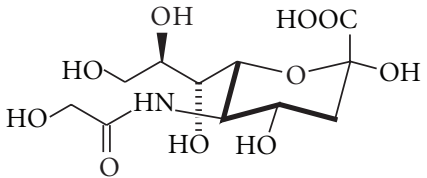

$N$-glycolyl- $\alpha$-neuraminic acid (Neu5Gc)

FIgURe 1: Sialic acids.

TABLE 1: GSL series.

\begin{tabular}{lc}
\hline Series & Core structure \\
\hline Arthro & GlcNAc $\beta 1,3 \mathrm{Man} \beta 1,4 \mathrm{Glc} \beta 1,1^{\prime} \mathrm{Cer}$ \\
Gala & $\mathrm{Gal} \alpha 1,4 \mathrm{Gal} \beta 1,1^{\prime} \mathrm{Cer}$ \\
Neogala & $\mathrm{Gal} \beta 1,6 \mathrm{Gal} \beta 1,6 \mathrm{Gal} \beta 1,1^{\prime} \mathrm{Cer}$ \\
Ganglio & $\mathrm{Gal} \beta 1,3 \mathrm{GalNAc} \beta 1,4 \mathrm{Gal} \beta 1,4 \mathrm{Glc} \beta 1,1^{\prime} \mathrm{Cer}$ \\
Globo & $\mathrm{GalNAc} \beta 1,3 \mathrm{Gal} \alpha 1,4 \mathrm{Gal} \beta 1,4 \mathrm{Glc} \beta 1,1^{\prime} \mathrm{Cer}$ \\
Isoglobo & $\mathrm{GalNAc} \beta 1,3 \mathrm{Gal} \alpha 1,3 \mathrm{Gal} \beta 1,4 \mathrm{Glc} \beta 1,1^{\prime} \mathrm{Cer}$ \\
Lacto & $\mathrm{Gal} \beta 1,3 \mathrm{GlcNAc} \beta 1,3 \mathrm{Gal} \beta 1,4 \mathrm{Glc} \beta 1,1^{\prime} \mathrm{Cer}$ \\
Neolacto & $\mathrm{Gal} \beta 1,4 \mathrm{GlcNAc} \beta 1,3 \mathrm{Gal} \beta 1,4 \mathrm{Glc} \beta 1,1^{\prime} \mathrm{Cer}$ \\
Muco & $\mathrm{Gal} \beta 1,3 \mathrm{Gal} \beta 1,4 \mathrm{Gal} \beta 1,4 \mathrm{Glc} \beta 1,1^{\prime} \mathrm{Cer}$ \\
Mollu & Fuc $\alpha 1,4 \mathrm{GlcNAc} \beta 1,2 \mathrm{Man} \alpha 1,3 \mathrm{Man} \beta 1,4 \mathrm{Glc} \beta 1,1^{\prime} \mathrm{Cer}$ \\
Schisto & $\mathrm{GalNAc} \beta 1,4 \mathrm{Glc} \beta 1,1^{\prime} \mathrm{Cer}$ \\
Spirometo & $\mathrm{Gal} \beta 1,4 \mathrm{Glc} \beta 1,3 \mathrm{Gal} \beta 1,1^{\prime} \mathrm{Cer}$ \\
\hline
\end{tabular}

root structures. The more comprehensive IUPAC system [22] is less frequently applied. According to Svennerholm, a core structure of neutral sugars define the name of a respective series, in which the pyranose forms of $\mathrm{D}$ galactose (Gal), D-N-Acetyl-glucosamine (GlcNAc), or D$N$-Acetylgalactosamine (GalNAc) are attached in defined order and linkage to lactosylceramide $(\mathrm{Gal} \beta 1,4 \mathrm{Glc} \beta 1 \mathrm{Cer})$ or $\beta$-galactosylceramide (Gal $\beta 1 \mathrm{Cer}$ ). The names contain information about the series ("G" = ganglio, "L" = lacto), the number of sialic acids ("A" $=0$, "M" $=1$, " $\mathrm{D}$ " $=2$, "T" = 3 , “Q" = 4, "P" = 5, “H” = 6, "S" = 7), and, indirectly, on the number of uncharged carbohydrates: initially it has been assumed that this number cannot exceed 5 , so that the name "ganglioside GM1" indicates that this ganglioside contains $(5-" 1 "=4)$ neutral sugars of the ganglio series. This series is defined by the sequence Gal $\beta 1-3 \mathrm{GalNAc} \beta 1$ $4 \mathrm{Gal} \beta 1-4 \mathrm{GlcC}$. Sialic acids can be attached once, twice, or severalfold to different positions within the core structures. Most often, they are found in $\alpha 2,3$-linkage to the "inner" or "outer" galactosyl residue, and in $\alpha 2,8$-linkage to other sialic acids. Ganglioside GM1 bears one sialic acid moiety connected to the 3-OH-group of the galactosyl residue in position II of the gangliotetraose moiety (see also Figure 7). The corresponding IUPAC-IUBMB short-hand name is $\mathrm{II}^{3} \mathrm{Neu} 5 \mathrm{AcGg}_{4} \mathrm{Cer}$. Structures of ganglio-series gangliosides can also be derived from the scheme of ganglioside biosynthesis (see below; Figure 12). In general, ganglio-series GSLs of the 0 -series bear no sialic acids on the galactose in position II, of the a-series bear one, of the b-series bear two, and of the c-series bear three sialic acid residues. However, GM1b and GD1c have a "b" and "c" in their names, although both are 0 -series gangliosides (see the scheme of ganglioside biosynthesis, Figure 12). GM4 is a gala-series ganglioside, although the "G" suggests ganglio series. Figure 2 shows the structure of ganglioside GQ1b, one of the most abundant gangliosides in adult human brain $(\mathrm{G}=$ ganglio series, $\mathrm{Q}=4$ sialic acids, $5-1=4$ neutral carbohydrate residues, and bseries $=2$ sialic acids attached to the "inner" galactose).

Ganglioside core structures can be additionally modified; they can be elongated, such as in GDlaGalNAc [25] (Figure 3). This ganglioside occurs, for example, on spinal neurons $[26,27]$ and can give rise to autoantibodies as a cause of variant forms of the Guillain-Barré syndrome [28, 29] and other neuropathies [30]. A modified GM2 derivative that contains taurine in amide linkage to the sialic acid carboxyl group has been identified in the brain of patients with Tay-Sachs disease [31]. Hybrid-type GSLs and gangliosides with postglycosylation modifications add further complexity to this substance class [32]. As an example, lacto-ganglio hybrid-type gangliosides have been identified in bovine brain [33].

Most gangliosides found in adult mammals belong to the ganglio, gala, lacto, and neolacto series. Ganglioside GM4 (Figure 3), a member of the gala series, has the structure NeuAc $\alpha 2,3 \mathrm{Gal} \beta 1 \mathrm{Cer}$ and is often found with an $\alpha$-hydroxyfatty acid within the ceramide moiety. During development, also gangliosides with other core structures are transiently formed, such as the stage-specific embryonic antigen SSEA4, a ganglioside of the globo series [34] (Figure 4). In adults, globo-series gangliosides occur on human erythrocytes [35], in human kidney [36], and on various stem cells [37]. For example, SSEA-4, but not SSEA-3 or Globo-H (Figure 4), is expressed in cord blood-derived mesenchymal stem cells [24].

With the exception of echinoderms (marine organisms of typically pentaradial symmetry), gangliosides are usually absent from invertebrates. Arthropods, for example, form acidic GSLs with a Man $\beta 1,4 \mathrm{Glc} \beta 1,1^{\prime}$ Cer core, which contain glucuronic acid instead of sialic acids. For gangliosides of echinoderms [38-42], there is no systematic short-hand nomenclature. They show structural features uncommon to mammalian gangliosides, such as sialic acid residues within the oligosaccharide moieties (e.g., LG-2, Figure 5), $\alpha 2,11$ linked sialic acids (e.g., LLG-5, Figure 5), sialic acid methylation or sulfation, or a glycosyl inositolphosphoceramide core, for example, $[43,44]$. In cultured neurons, echinodermal gangliosides show neuritogenic and growth-inhibitory activities. In this regard, they are more potent than other 


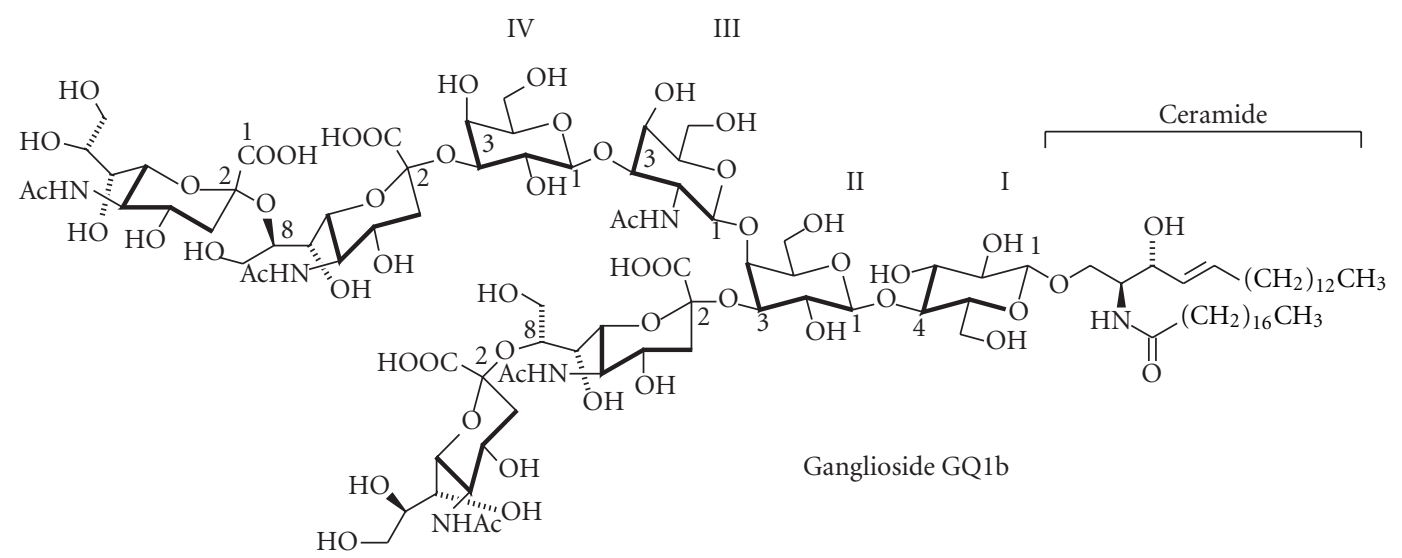

FIGURE 2: Structure of GQ1b, one of the most abundant gangliosides in adult human brain, which is involved in long term potentiation, synaptic plasticity, and improvement of cognitive function [23].
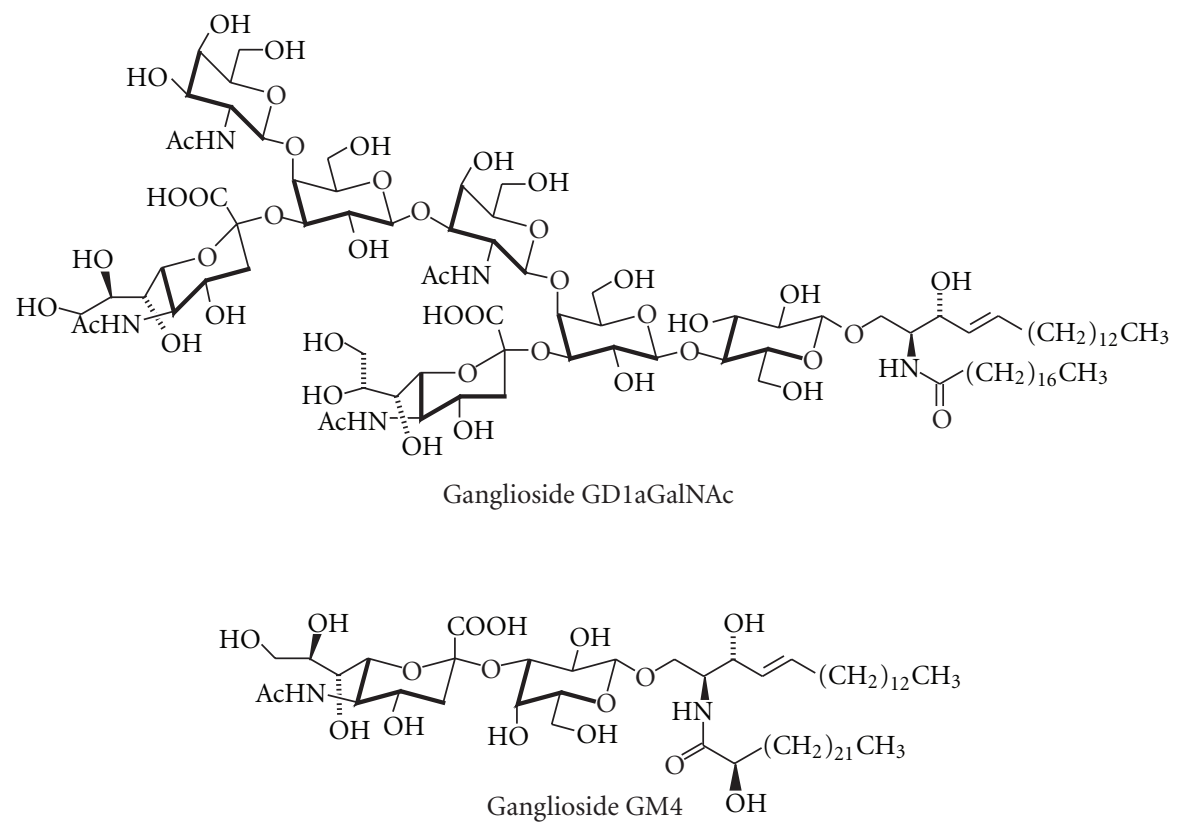

FIgURe 3: GD1aGalNAc and GM4.

gangliosides $[45,46]$ and potentiate the neuritogenic effect of nerve growth factor.

Heterogeneity is not only found within the glycan part, but also within the ceramide moiety. This can consist of different sphingoid bases [51], sphinganine, sphingosine, and phytosphingosine of different chain lengths (Figure 6), which can be further modified by $\mathrm{O}$-acetylation [52]. In higher animals, $\mathrm{C}_{18^{-}}$and $\mathrm{C}_{20}$-sphingosine are the most abundant sphingoid bases of gangliosides.

The fatty acids found in the ceramide part of gangliosides are mostly saturated. $\alpha$-Hydroxylated fatty acids [53] are not frequently found in brain gangliosides, but are, for example, abundant in gangliosides from intestine, liver, or kidney, and in GM4. To specify the lipoform of a ganglioside, designations such as (d18:1/18:0)GM3 are used for a II $^{3}$ Neu5AcLacCer with a sphingosine $(\mathrm{d}=$ dihydroxy, $1=$ one double bond; see also Figure 6) of 18 carbons and a stearoyl residue (18:0) within the ceramide portion. The functional consequences of the heterogeneities in the lipid component are largely unknown, but the lipid part can mask the receptor function of ganglioside glycans via interaction with membrane cholesterol $[54,55]$. As another example, the ceramide portion of GM1 dictates retrograde transport of cholera toxin bound to GM1, and only GM1 with unsaturated acyl chains is sorted from the plasma membrane to the trans-Golgi network and the ER [56]. Ganglioside profiling with respect to glycan and ceramide structures is more and more in the focus of ganglioside analysis.

\section{Occurrence}

Gangliosides are especially abundant in the brain, where their occurrence in the grey matter is about 5 -fold higher than in white matter. In adult human brain regions, the 


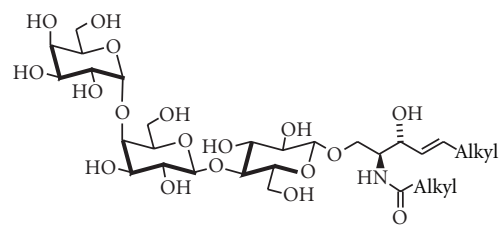

$\mathrm{Gb}_{3} \mathrm{Cer}$

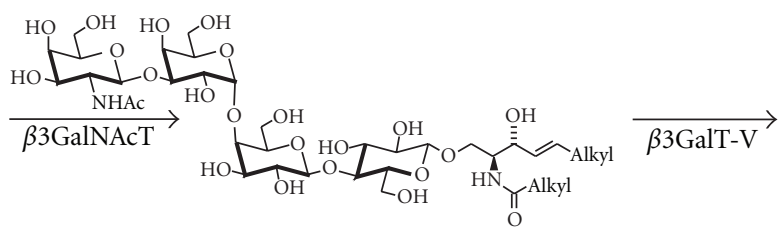

$\mathrm{Gb}_{4} \mathrm{Cer}$

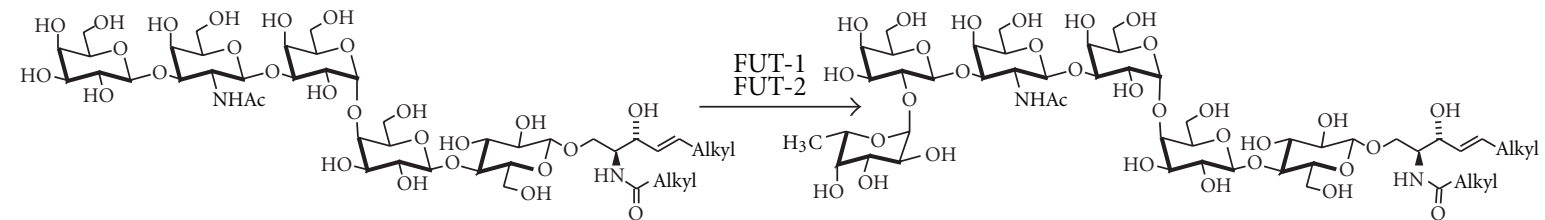

SSEA3

ST3Gal-II

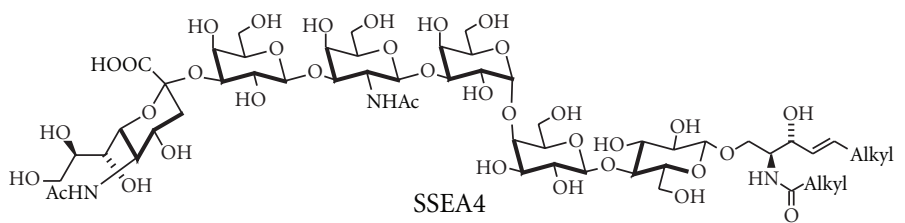

FIGURE 4: Formation of SSEA-4 from globotriaosylceramide (Gb3Cer). SSEA, stage-specific embryonic antigen; T, transferase; FUT, fucosyltransferase (modified from [24]).

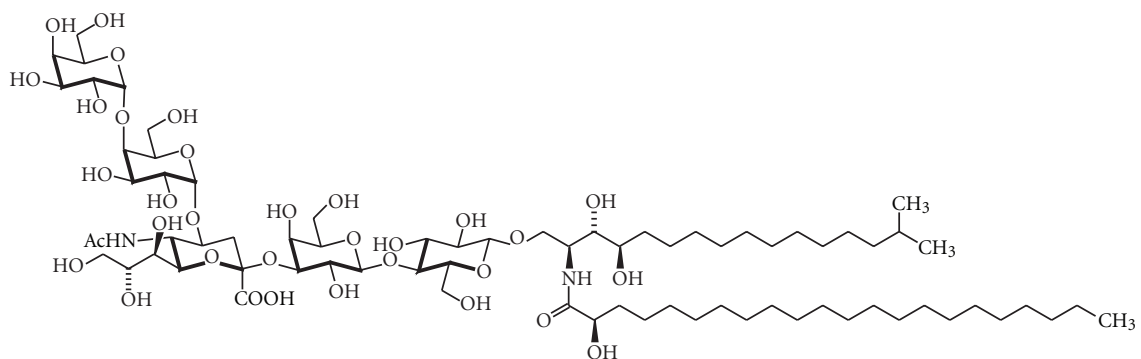

LG-2

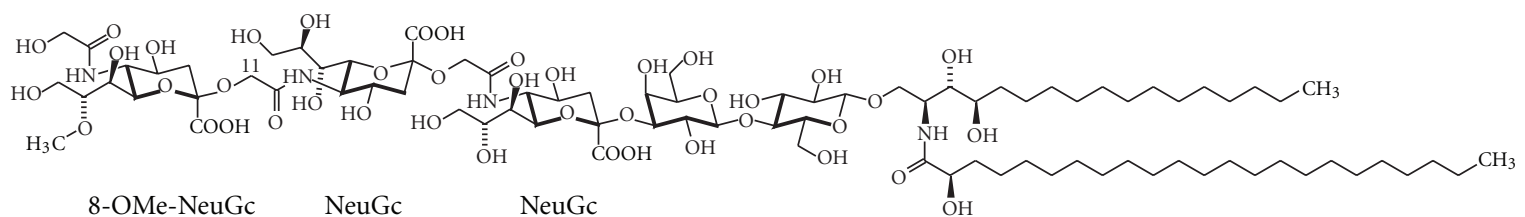

LLG-5

Figure 5: Examples for gangliosides from echinoderms: LG-2 from the starfish Astropecten latespinosus [47] and LLG-5 from the starfish Linckia laevigata $[48-50]$.

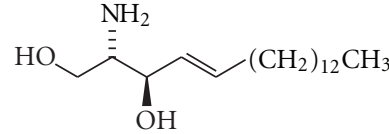

Sphingosine<smiles>CCCCCCCCCCCCCCCCCCCC(N)CO</smiles>

Sphinganine

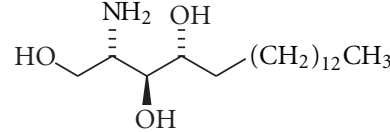

D-ribo-phytosphingosine

FIGURE 6: Representative structures of sphingoid bases, in this case (d18:1), (d18:0), and (t18:0). 
values range from 2 to $14 \mu \mathrm{g}$ lipid-bound sialic acid/mg protein [57]. In the brain, ganglioside expression correlates with neurogenesis, synaptogenesis, synaptic transmission, and cell proliferation $[58,59]$. In cultured murine hippocampal neurons, axonogenesis, but not dendritogenesis, is accompanied by an increase in the formation of complex gangliosides and by a shift from the a- to b-series [60]. In extraneural tissues, the ganglioside content is one- to twoorders of magnitude lower than in the brain; relatively high concentrations of ganglio-series gangliosides are found in bone marrow, erythrocytes, intestine, liver, spleen, and testis, GM4 in kidney, and SSEA-4 in embryonic stem cells. Cellular gangliosides form in part complex, cell-type- and tissue-specific glycan patterns [61]. These are not stable with time, but change with physiological and pathophysiological processes such as cell growth, differentiation, viral transformation, ontogenesis, oncogenesis, embryogenesis [62, 63], lactation, or tumor progression [64]. Gangliosides of the ganglio-series are especially found in the nervous system, where they contribute to $10-12 \%$ of the lipid content [65]. During brain development, the ganglioside pattern changes from the prevalence of the simple gangliosides GM3 and GD3 to more complex ones such as GD1a and GT1b [66] (for structures, see Figures 7 and 11). Ganglioside content and composition of the brain change also during aging: for example, the amount of lipid-bound sialic acid decreased from $1070 \mu \mathrm{g} / \mathrm{g}$ wet weight in a 25 -year-old healthy proband to $380 \mu \mathrm{g} / \mathrm{g}$ wet weight in a 85 -year-old individual. Despite this, the concentrations of GQ1b, GT1b, and GD1b increase with age at the expense of GM1 and GD1a [67] (for structures, see Figures 2 and 7). Changes in ganglioside composition with age also occur in liver [68]. There are only indications on the functional consequences of such changes [23].

Gangliosides are also found in serum. There, especially GM3, GD3, GD1a, GM2, GT1b, sialylneolactotetraosylceramide (Figure 10), GD1b, and GQ1b are present, where about $98 \%$ of them are transported by serum lipoproteins, predominantly by LDL $(66 \%)$, followed by HDL $(25 \%)$ and VLDL (7\%) [69]. After the discovery of extracellular microvesicles (formerly called microparticles) [70], which were not distinguished from lipoproteins in earlier experiments, it might turn out that these assignments have to be revised.

Experiments in rats have shown that after injection of $\left[{ }^{14} \mathrm{C}\right]$ sialic acid-labeled gangliosides GM3 and $\left[{ }^{3} \mathrm{H}\right]$ sphingosine-containing labeled ganglioside GM1, the GM1 and GM3 probes had serum half-lives of 1.4 and $1.8 \mathrm{~h}$, respectively. After three hours, $75 \%$ of the GM1 and 38\% of the GM3 probes were taken up by the liver, and a smaller extent in the central nervous system, kidneys, and lung [71].

Subcellularly, the majority of gangliosides resides in the plasma membrane [72]. However, gangliosides also occur in organellar membranes such as in mitochondria, where GD3 regulates apoptosis [73], and in the nucleus, where they are involved in $\mathrm{Ca}^{2+}$ balance $[74,75]$.

The glycans found in gangliosides are sometimes modified by the acylation of sialic acid residues in different positions [20]. O-Acetylated sialic acids in gangliosides occur especially in growing cells and tissues and are regarded as oncofetal markers present on different tumors [76]. They also serve as receptors for Influenza $\mathrm{C}$ viruses or coronaviruses [77].

Another modified sialic acid is $\mathrm{N}$-glycolylneuraminic acid (Neu5Gc) [42]. With the exception of certain tumors and in fetuses, it is found only in trace amounts in human tissues [78]. As a component of glycoconjugates, Neu5Gc is known as the Hanganutziu-Deicher antigen [79]. It is abundant in many species of the Deuterostome lineage, including simians, mice, rat, beef, pork, or lamb, but is nearly absent from birds and reptiles [80]. Neu5Gc on glycoconjugates contributes to xenoantigenicity in pig-human xenotransplantation [81], and in cats, Neu5Gc distinguishes the blood groups A and B: [Neu5Gc $]_{2} \mathrm{GD} 3$ is found in feline blood group A erythrocytes, [Neu5Ac] $]_{2} \mathrm{GD} 3$ on blood group B, and feline blood group $\mathrm{AB}$ erythrocyte membranes contain $[\mathrm{NeuGc}]_{2} \mathrm{GD} 3$, [Neu5Ac,Neu5Gc]GD3, and [NeuAc] ${ }_{2} \mathrm{GD} 3$ [82].

Humans cannot synthesize Neu5Gc due to an irreversible inactivation of the $\mathrm{CMAH}$ gene on chromosome 6p21.32 encoding Cytidine monophosphate- $\mathrm{N}$-acetylneuraminic acid hydroxylase [83]. This enzyme converts CMPNeu5Ac to CMPNeu5Gc and its function is thought to be lost during a "sialoquake" in human evolution [84, 85]. Determination of Neu5Gc and Neu5Ac-containing gangliosides is either achieved by classical chromatographic techniques combined with antibody staining [86], or, with higher sensitivity, by combination of chromatography with ESI-MS [87]. A potential application is the immunochemical detection of [Neu5Gc]GM3 as biomarker of nonsmall-cell lung cancer [88].

Also ganglioside lactones (Figure 8) have been detected in various tissues, for example, GD3 lactone in mouse brain [89] and GD1b lactone in human brain [90]. Ganglioside lactones are more immunogenic than gangliosides [91] and occur on tumor cells such as melanoma as tumor-associated antigens. In vitro, lactonization of gangliosides can be followed by a strong negative Cotton effect at $235 \mathrm{~nm}$ in CD spectroscopy [92].

Temporal and spatial differences are also observed for the ganglioside lipid part. In undifferentiated neuronal cell cultures, gangliosides with $\mathrm{C}_{20}$ sphingosine are present only in trace amounts, but their content increases with the onset of cell differentiation [93]. In rat brain, the fraction of gangliosides containing $\mathrm{C}_{20}$ sphingosine increases with age [94] in cerebellum [95] or forebrain [96]. Spatial differences regarding the sphingoid base chain length have also been detected in mice: while gangliosides containing $\mathrm{C}_{18}$ species were widely distributed throughout the frontal brain, $\mathrm{C}_{20}$ species are selectively localized along the entorhinalhippocampus projections [97]. Fatty acid and sphingoid base composition is also different between human motor and sensory nerves [98].

Nutrition. Since gangliosides are components of most vertebrate cell types, they are ingested with the nutrition, for example, with egg yolk (GM3, GM4, and GD3), meat, or in 

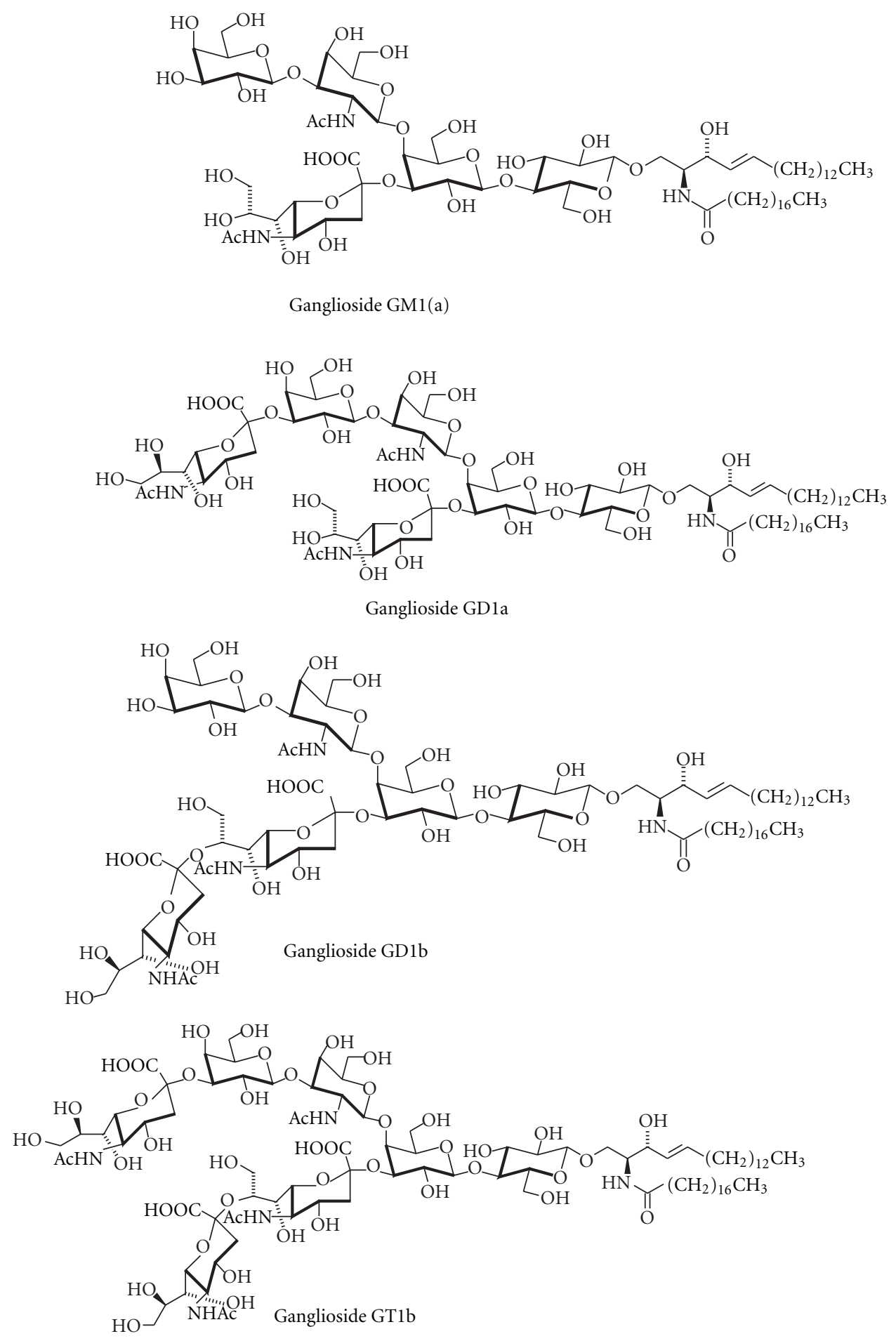

FIGURE 7: Representative structures of gangliosides that are abundant in adult human brain.

milk [99]. Milk contains gangliosides, especially GD3 and GM3, in the membrane fraction of the fat globule. Dietary gangliosides modify the intestinal microflora and prevent infections during early infancy [100]. In infants, more than $80 \%$ of dietary gangliosides survive the passage through the stomach, in part with acid-catalyzed lactonization, and are absorbed in the intestine [99]. Ingestion of dietary gangliosides leads to an increase of gangliosides in serum. In human nutrition, sialic acid derived from gangliosides and other glycoconjugates is an essential nutrient for the rapidly growing brain in infants [59]. The pathophysiological consequences of nutritional Neu5Gc uptake are unknown. 


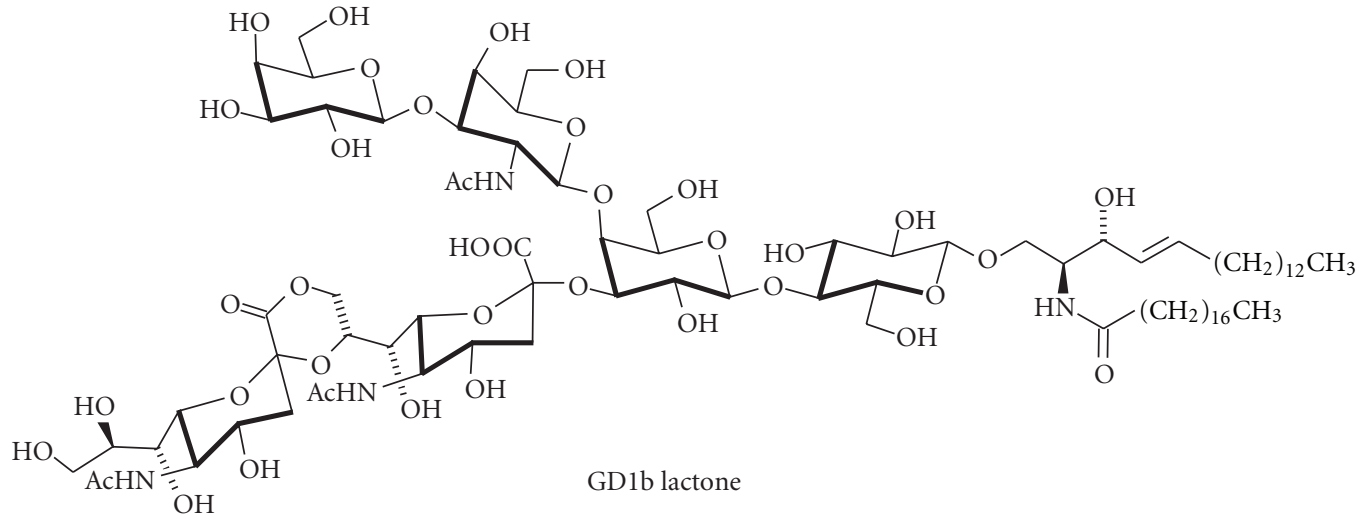

FIgURE 8: Example of a ganglioside lactone.

\section{Analysis}

In the past, ganglioside structures and levels were obtained by comprehensive chemical analysis, while nowadays this is attempted within lipidomics using mass spectrometry as the key technology [101].

In general, gangliosides are isolated from tissues and body fluids by chloroform-methanol extraction [102, 103]. Extraction efficiency can increase when small amounts of water are present in the extraction solvent [104], for example, using the solvent system chloroform: methanol: water $(5: 5: 1)$ [105]. When extraction is followed by a partition step such as that developed by Folch et al. [106], gangliosides - in contrast to the majority of other lipid classes-partition into the upper, aqueous phase. From there, they can be isolated by a solid phase extraction and separated from neutral GSLs by anion exchange chromatography [107], such as with DEAE (=diethylaminoethyl) Sephadex [108].

O-Acetylation of sialic acids and also ganglioside lactonization [90] are modifications that are lost under alkaline conditions. These are often applied to remove glycerophospholipids that contain fatty acids in ester linkage [109]. If information on these modifications is desired, gangliosides from tissues can be determined without alkaline treatment, for example, after chloroform/methanol extraction in a ratio of $1: 2$ and a subsequent partition step [110].

Separation of gangliosides according to their glycan composition is achieved by thin layer chromatography (TLC) [111] and by HPLC and other techniques that can be coupled to mass spectrometry [112]. This facilitates their identification by mass spectrometry and is required for their characterization by staining with suitable antibodies $[113,114]$, lectins, or other binding proteins [115]. Although not required for mass-spectrometric profiling, separated ganglioside classes can also be further separated according to their ceramide structure by reversed phase chromatography [116-118].

Quantification can be achieved by staining and densitometry, or-if suitable standard substances are availableby mass spectrometry. Since the biosynthetic machinery generates heterogeneities within both, the lipid and the glycan part, comprehensive ganglioside analysis is a highly demanding task within lipidomics [101]. In addition to glycoforms that are also well known from glycoprotein analysis, "lipoforms" [119] become increasingly important to understand ganglioside metabolism and function. Various protocols for ganglioside determination by mass spectrometry have been developed [101]. They are largely based on electrospray mass spectrometry as ionization technique; but also MALDI plays a role. The available methods range from preanalytics to bioinformatic data handling and include imaging methods using MALDI and Secondary Ion mass spectrometry (SIMS) to determine the spatial distribution of the analytes [101]. In addition to their constitution, little is known about the conformation of gangliosides in their native, membrane-bound surroundings. X-ray data are not available for gangliosides, although isolated glycans have been investigated by various means. For a simulation of GM3 conformations in a bilayer, compare [120], which, for example, shows that the glucose moiety of GM3 is buried within phosphatidylcholine head groups.

\section{Biosynthesis}

The diversity of cell surface glycans, including that of gangliosides, is generated within the Golgi apparatus [121], and the heterogeneities within the ceramide part result from the biosynthesis of ceramide at the endoplasmic reticulum (ER). De novo synthesis of gangliosides can be distinguished from salvage processes $[122,123]$, in which sialic acids, sugars, fatty acids, and sphingoid bases are recycled. The latter process can predominate by far in differentiated cells.

5.1. Ceramide Biosynthesis. Ganglioside biosynthesis starts with the formation of ceramide (Figure 9) at the cytoplasmic leaflet of the ER membrane [124-126]. The first step, the condensation of L-serine and a coenzyme A-activated fatty acid is catalyzed by the pyridoxal phosphate-dependent serine palmitoyltransferase (SPT) [127]. The incorporation of L-serine into GSLs can be used to monitor their de novo biosynthesis using L-serine radiolabelled in the position 3 
(the carbon in position 1 is lost as carbon dioxide). In the brain, the external supply of L-serine by astrocytes is essential for neuronal lipid biosynthesis and brain development [128]. In agreement with this observation, genetically engineered rodents with deficient phosphoglycerate dehydrogenase required for L-serine formation from $\mathrm{D}$-glucose show drastically reduced ganglioside levels, defects in brain morphogenesis, and drastically reduced lifespan $[129,130]$.

The next step in sphingolipid biosynthesis is the $\mathrm{NADPH}$-dependent reduction of 3-ketosphinganine to sphinganine by 3-ketosphinganine reductase, followed by acylation of sphinganine to dihydroceramides of different chain lengths [131]. During salvage, also other sphingoid bases are acylated by $\mathrm{N}$-acyltransferases of the lass family. Lass 1 encodes ceramide synthase 1 , which is expressed in the brain and involved in the formation of the membrane anchor of gangliosides. In mice, spontaneous recessive mutations in the lass1 gene are associated with cerebellar ataxia and Purkinje cell degeneration [132]. Although the ceramide part of brain gangliosides contains mostly nonhydroxylated fatty acids, apparently all members of the lass family are also able to transfer the corresponding 2-hydroxy-fatty acids [133]. Dihydroceramides are dehydrogenated to ceramide by the dihydroceramide desaturase des1 [134], or hydroxylated to phytoceramides by des2. Ceramide is the common precursor of GSLs and sphingomyelin and is transported to the Golgi apparatus at least in part in a protein-dependent manner by the transport protein CERT [135-137].

5.2. General Aspects of Ganglioside Formation. GSL synthesis continues by the stepwise transfer of nucleotide-activated monosaccharide units first on ceramide and then on GSLs with growing glycan chains. Glycosidation is coupled to exocytosis through the Golgi apparatus to the plasma membrane [138] at the rate of bulk vesicle flow [139].

The complex ganglioside and GSL glycoforms on eukaryotic cell surfaces are generated by only a few enzymes that act within a combinatorial biosynthetic pathway [140, 141]. The first glycosyltransferases involved in ganglioside biosynthesis have been characterized in the laboratories of Roseman and Basu [142]. According to the number of sialic acids connected to the "inner" galactosyl residue, ganglioseries gangliosides are classified into members of the 0-, a-, b-, and c-series (Figure 12). b-Series gangliosides contain the Neu5Ac $\alpha 2,8$ Neu5Ac sequence, which is commonly not found in glycoproteins. Higher members of these different subseries can be formed by the action of the same glycosyltransferases, which show less specificity than those acting early in the pathway [143-147].

The glycosyltransferases and sialyltransferases $[148,149]$ of the ganglioside biosynthetic pathway are expressed in a cell-type- and developmental-dependent fashion. Ganglioside pattern changes during the development of the brain [150], and after differentiation, differences in glycolipid composition have even been found between different neuronal cell types [151]. In addition, ganglioside patterns vary between different cell types and change with the differentiation of the cell. As an example, $\beta 1,3-N$-acetylglucosaminyl- transferase expression, which leads to the formation of glycolipids of the lacto and neolacto series (Figure 10), is high during murine embryonic development and decreases after birth to undetectable levels in most cell types $[152,153]$. In adult animals, expression is high in spleen [154], and in cerebellum, it is restricted to Purkinje cells [155].

GSLs including gangliosides are formed biosynthetically at intracellular membranes from which they are transported to the plasma membrane by exocytotic membrane flow [138]. While many human diseases are known that are due to defects in GSL and sphingolipid degradation, the only known human disease caused by a defect glycosyltransferase of ganglioside biosynthesis is the human autosomal recessive infantile-onset symptomatic epilepsy syndrome, which is caused by a nonsense mutation in the gene encoding GM3 synthase [156].

A principal difference between ganglioside biosynthesis in the Golgi apparatus and degradation in the endolysosomal compartment is that during GSL formation, membranebound glycosyltransferases interact with their membranebound glycolipid substrates by diffusion within the twodimensional plane of the lipid bilayer. Therefore, reaction rates can become independent of the reaction volume and obey two-dimensional enzyme kinetics. This means that kinetic constants can be normalized on lipid surface area instead of reaction volume, for example, in terms of the amount of membrane protein [157]. As a consequence, glycosyltransferases that lack their transmembrane domain lose most of their activity towards membrane bound substrates [158]. During degradation in endosomes and lysosomes, the glycosidases are soluble enzymes, and the substrates are membrane-bound. This explains in part the requirement for endosomal and lysosomal lipid-transfer proteins for the degradation of GSLs with short glycan chains, which is not the case in biosynthesis. In addition to ganglioside biosynthesis in the Golgi apparatus, there are also indications ganglioside formation by plasma membrane-associated glycosyltransferases [159].

5.3. Gala Series. In the monoglycosylceramides glucosylceramide (GlcCer) and galactosylceramide (GalCer), which are also called cerebrosides, the hexosyl residues are present in $\beta$ anomeric configuration. GalCers with $\alpha$-configuration occur only in lower organisms [42] and are highly immunogenic for mammals [160]. Most gangliosides are biosynthetically derived from GlcCer; only ganglioside GM4 is derived from GalCer. Ganglioside GM4 has been discovered as a minor component of human brain gangliosides [161], where it is localized within myelin [162]. It also occurs, for example, on erythrocytes, kidney, and in the intestine and is abundant in some fish species. However, the most frequently found members of the gala series are GalCer and sulfatide (GalCer3 -sulfate) in oligodendrocytes, Schwann cells, kidney, testis, and intestine. They are present in high concentrations in the multilamellar layers of the myelin where they are required for glial adhesion [163], apparently via interaction between the carbohydrate head groups of sulfatide and GalCer on different myelin layers [164]. Myelin lipids contain the highest fraction of 2-hydroxy-fatty acids, which are 


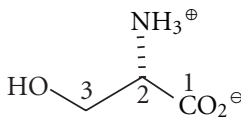

L-Serine
$+\mathrm{CH}_{3}\left(\mathrm{CH}_{2}\right)_{14} \mathrm{COSCoA}$

Palmitoyl CoA

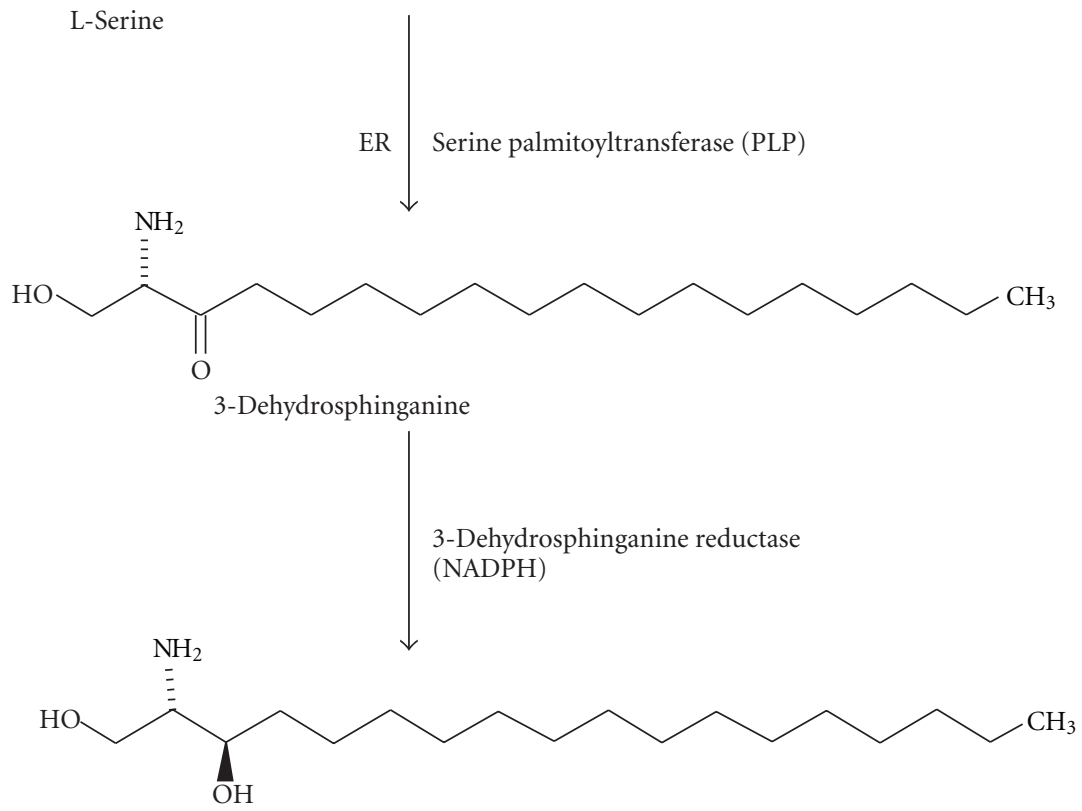

D-erythro-Sphinganine

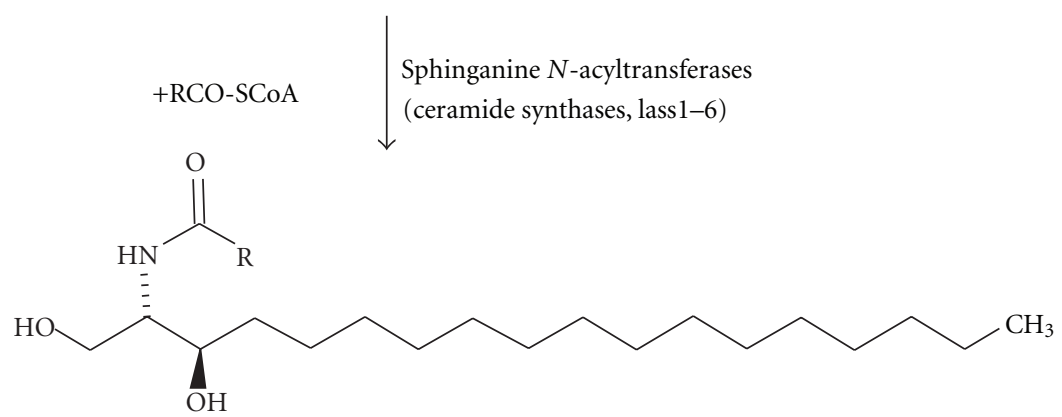

D-erythro-Dihydroceramide

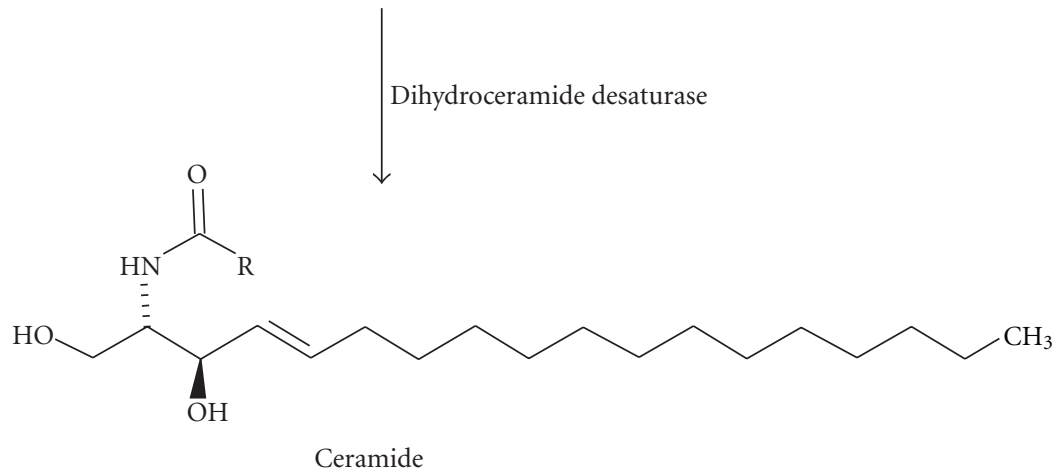

FIgURE 9: Ceramide biosynthesis, shown for a ceramide with $\mathrm{C}_{18}$ sphingosine. $\mathrm{R}=$ alkyl; chain length depend on the availability of the corresponding acyl CoAs and the identity of the ceramide synthase. 


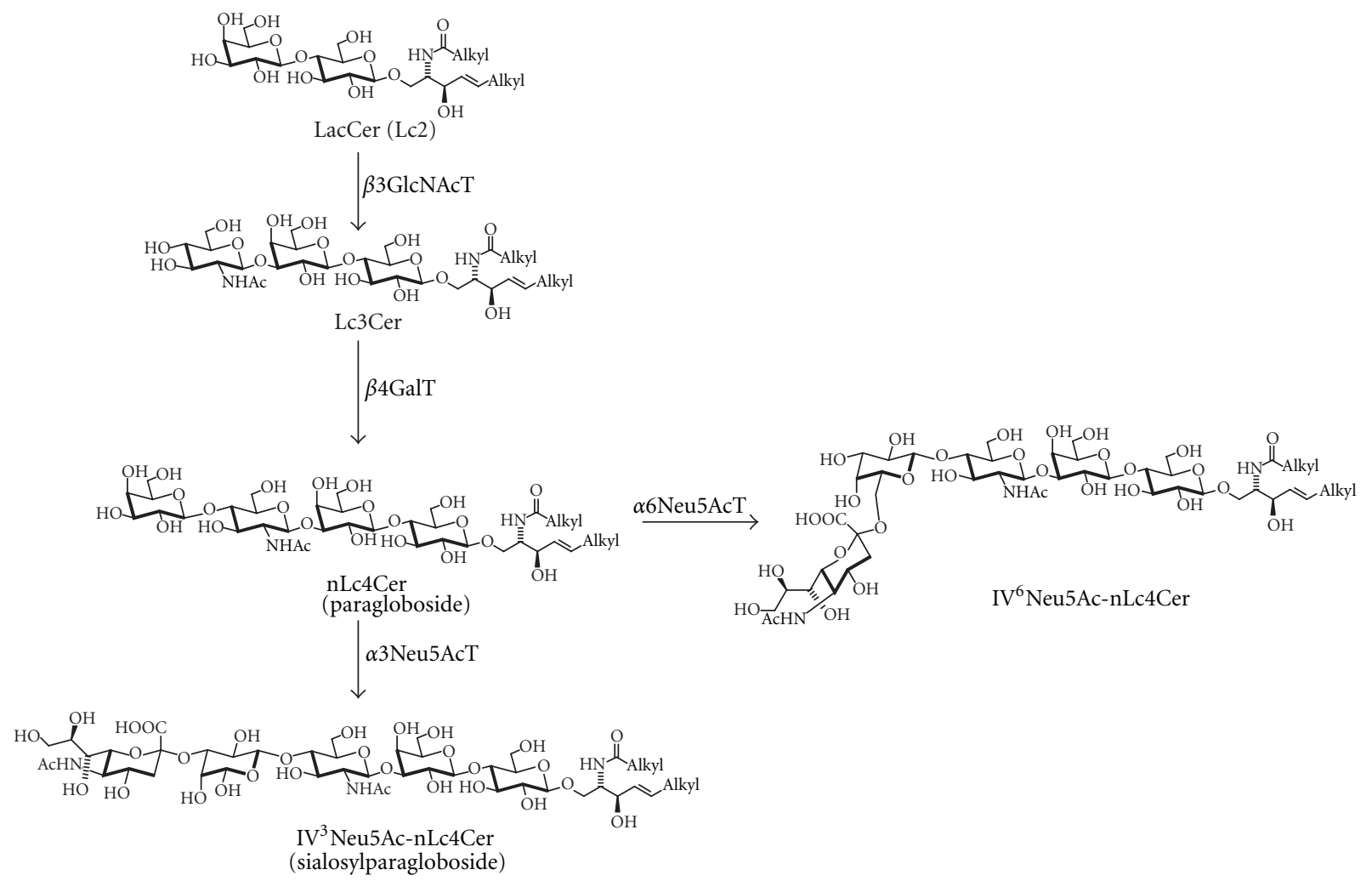

FIGURE 10: Reaction of $\beta 1,3-N$-acetyl-glucosaminyltransferase ( $\beta 3$ GlcNAcT) and examples of downstream gangliosides of the neolacto series.

formed by fatty acid hydroxylase-2 [165]. Their presence in gala-series GSLs contributes to carbohydrate-carbohydrate interactions between the GSLs [166].

In contrast to GalCer synthase, GlcCer synthase appears to be dispensable for oligodendrocytes [167]. While ceramide galactosylation catalyzed by UDP-glucose:ceramide galactosyltransferase (GalT3) [168] occurs at the ER membrane, the later steps of gala-series GSL biosynthesis, formation of sulfatide [169], digalactosylceramide [170], and ganglioside GM4 take place in the lumen of the Golgi apparatus. In contrast to most glycosyltransferases in ganglioside biosynthesis, which are type II transmembrane proteins, ceramide galactosyltransferase is a type I transmembrane protein with the catalytic domain on the luminal side of the ER [171]. According to data obtained in zebrafish and mice, GM4 can be formed by ST3Gal V, which can also make GM3. Therefore, GM4 and GM3 formation appear to depend on the availability of their precursors, GalCer and LacCer [172]. Little is known about the function of GM4. It can interact with the myelin basic protein, shows immunosuppressive properties, and can prevent experimental allergic encephalomyelitis in guinea pigs [173].

5.4. Gangliosides Derived from Glucosylceramide. The first step in the biosynthesis of most gangliosides is the transfer of a glucose residue from UDP glucose to ceramide catalyzed by UDP-glucose:ceramide glucosyltransferase $[174,175]$. Although GlcCer and GalCer synthases catalyze similar reactions, their cDNAs share no sequence homology. Ceramide glucosyltransferase is a type III transmembrane protein. It forms noncovalent dimers or oligomers [176] with their Cterminal catalytic domains in the cytosol [177]. Since the formation of GlcCer occurs on the cytoplasmic face [178] and that of LacCer on the luminal site of the Golgi membrane [179], glucosylceramide has to be translocated across a membrane. This is mediated by a flippase of unknown identity: the $\mathrm{ABC}$-transporters, $\mathrm{ABC}-\mathrm{B} 1$ and $-\mathrm{C} 1$, translocate short chain GlcCer analogs through the Golgi membrane [180, 181]. Transversal translocation can be carried out after transport of GlcCer by the cytoplasmic lipid-transfer protein FAPP2 (four-phosphate adaptor protein 2) either to the ER [182], where it might be translocated by an uncharacterized flippase [183], or at the trans-Golgi [184]. A part of the GlcCer pool can reach the cytosolic leaflet of the plasma membrane where it can be degraded by the $\beta$-glucosidase Gba2 [185]. Candidate cytosolic GlcCertransporters are the glycolipid transfer protein GLTP and FAPP2.

The biosynthesis of higher gangliosides occurs on the luminal face of the Golgi apparatus [186], so that their glycan chains are orientated extracytoplasmic. LacCer is formed by galactosyltransferase I, which transfers a galactose residue from UDP galactose to glucosylceramide [187]. Further 


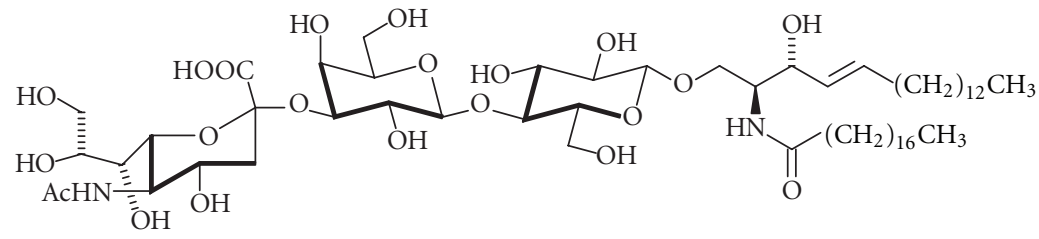

Ganglioside GM3

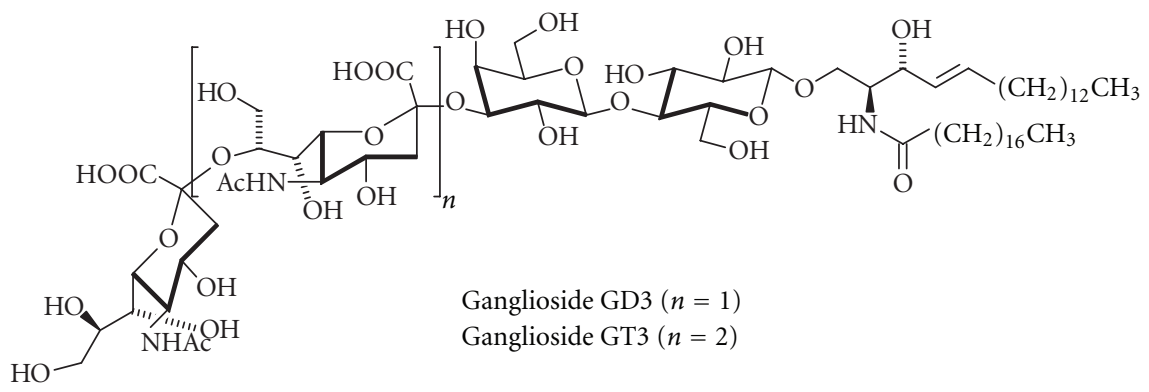

FIGURE 11: Structures of hematosides.

carbohydrate residues are transferred in a stepwise manner to the growing glycan chains. LacCer and its sialylated derivatives, the hematosides GM3, GD3, and GT3 (Figure 11) serve as precursors for complex gangliosides of the $0-$, a-, b-, and c-series.

These different series (Figure 12) are characterized by the presence of no (0-series), one (a-series), two (b-series) or three sialic acids residues linked to the position 3 of the "inner" galactosyl residue. In adult mammalian brain, gangliosides from the 0 - and c-series are found only in trace amounts, and GM1b and GD1 $\alpha$ are transiently expressed during chick brain biogenesis [188]. 0-series gangliosides (GM1b, GD1c, and GD1 $\alpha$ ) are found in genetically engineered mice deficient in ST3Gal V (GM3 synthase), where they are present in amounts that correspond to the total ganglioside content of normal animals [189]. These mice are not able to form GM3 and higher gangliosides of the a-c-series. They display altered glucose homeostasis with an accelerated insulin receptor signalling pathway, a key finding that demonstrates the inhibition of the insulin receptor by GM3 or a higher ganglioside derived from it in vivo [189].

c-Series gangliosides (Figures 12 and 13) are formed during mammalian brain development where they are thought to be involved in growth, differentiation, and migration of neuronal cells. They are abundant in fish brain, and in adult rats; they occur in liver, kidney, and pancreas [190] and in tumors such as glioma. The transferases that catalyze the first steps in ganglioside biosynthesis show high specificity towards their glycolipid substrates. The relative amounts of LacCer, GM3, GD3, and GT3 seem to determine the amount of $0-$, a-, b-, and c-series gangliosides. The glycosyltransferases that act late in this pathway represent a kind of assembly line and transfer the respective carbohydrates to glycosyl acceptors that differ only in the number of sialic acid residues bound to the "inner" galactose residue. The complex " $\alpha$-" gangliosides with sialic acid moieties in $\alpha 2,6$-glycosidic linkage to $N$-acetylgalactosamine residues is specific for cholinergic neurons [191] and has been added later to the biosynthetic scheme [192]. In mice, the sialyltransferases that form gangliosides GD1a and GT1b have been identified as ST3Gal II and ST3Gal III [193].

5.5. Genetically Engineered Mice. A significant advance towards understanding the function of the complex ganglioside pattern found in eukaryotic cells is the development of mice with defects in distinct biosynthetic steps [194]. A mouse melanoma cell line deficient in GlcCer and GlcCer-derived GSLs was viable and showed only minor changes in cellular morphology and growth rate. From these observations it was concluded that GSLs including gangliosides are not essential for animal survival [195]. Later, it was reported that mice with targeted disruption of the ceramide glucosyltransferase gene displayed no cellular differentiation beyond the primitive germ layers and died around day 7.5 of embryonic development [62]. Mice deficient in B4GalNT I (GM2synthase) are not able to form GM2, GD2, and higher gangliosides derived from them. Although these animals show only subtle impairment of brain function [196], they exhibit multiple defects, such as axonal degeneration, defects in myelination [197] and motor function [198], or an impaired response of $\mathrm{T}$ cells to interleukin 2 [199], only to mention a few. Later studies showed that CD4- and CD8-positive $\mathrm{T}$ cells require different ganglioside subsets for activation [200]. The mutant male mice are sterile and also show morphological and functional defects in the testis [196]. Further examination of GalNAc-transferase deficient mice revealed that GM1-deficiency is accompanied by Parkinsonlike symptoms, which could be rescued by L-Dopa or the membrane permeable GM1-analog Liga20 (see Figure 19) [201]. This is in agreement with a series of reports that GM1 can alleviate symptoms in models of Parkinson disease, 


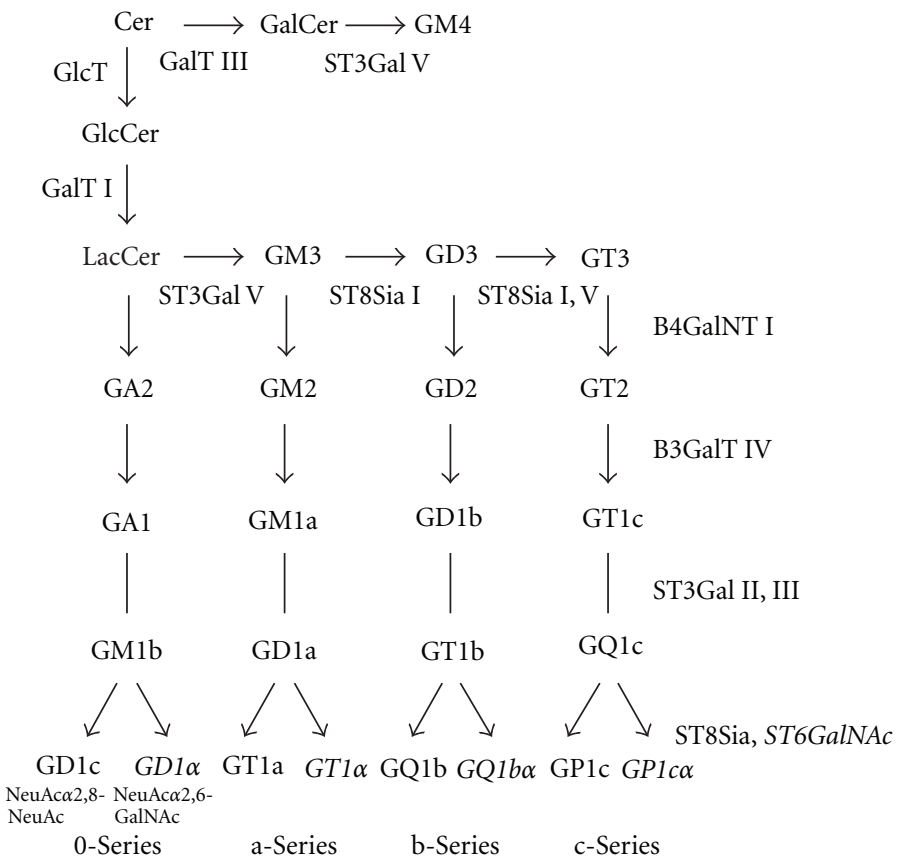

FIGURE 12: Ganglioside biosynthesis (modified from [141]).

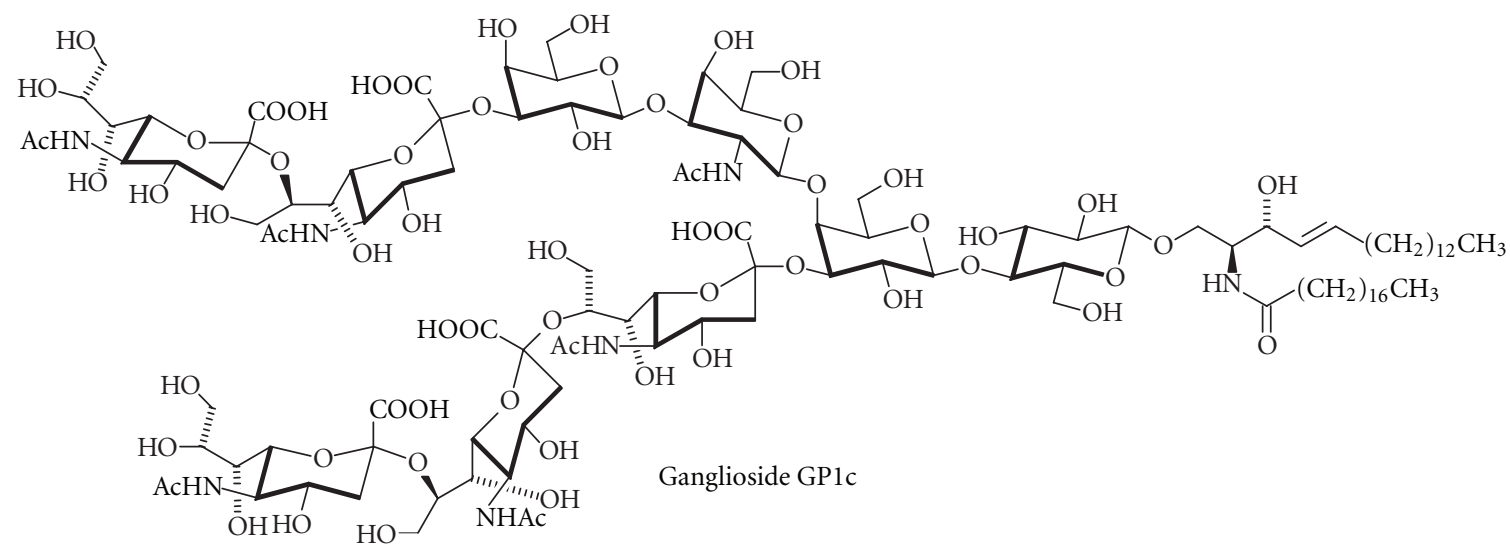

FIGURE 13: Structure of a c-series ganglioside.

for example, [202]. In Parkinson disease, anionic lipids and especially GM1 inhibit aggregation of $\alpha$-synuclein to cytotoxic fibrils [203].

Mice deficient in ST8Sia I (GD3-synthase) do not form GD3 and b-series gangliosides. They have a normal life span and are without detectable developmental defects [204]. When these mice were crossbred with mice carrying a disrupted B4GalNT I gene, the resulting double mutant mice express only ganglioside GM3 as their major ganglioside. These "GM3-only-mice" are extremely susceptible to sound stimuli, develop lethal seizures, and display a sudden death phenotype [204]. Double knockout mouse deficient in B4GalNT I and ST3Gal V (GM3-synthase) are not able to form any ganglioside of the ganglio-series. These animals are severely diseased and show elevated levels of LacCer, LacCersulfate, and traces of other gangliosides that are present also in normal brain [205].

5.6. Regulation. Sphingolipid biosynthesis is a highly regulated process and also coordinated with sterol and glycerolipid biosynthesis. Sphingolipids are major regulators of lipid metabolism and activate sterol-regulatory element binding proteins (SREBPs) [206]. The sphingomyelin synthaserelated synthase, the ceramide transporter CERT, and proteins of the orosomucoid- (Orm)-familie seem to play key roles in sphingolipid homeostasis [207]. Ganglioside pattern are characteristic for a cell type in a certain differentiation state, and, for example, mice deficient in GM3-synthase 
that cannot form the typical brain gangliosides show a ganglioside content similar to that of normal animals [189]. How exactly the relative amounts of gangliosides are controlled is not clear [208], but the transcriptional regulation of transferase genes seems to be a key point [208]. The picture gets more complicated by the fact that different transferase isoforms with different properties can be present: three murine GM3-synthase isoforms that arise from two transcripts have been characterized. One is resident in the ER membrane, the two others in the Golgi, but with different half-life [209]. In addition, the kinetic parameters of the transferases, their topological organization within the Golgi apparatus, or spatial neighborhood to other transferases will influence the resulting ganglioside pattern. An attempt has been made to calculate glycolipid pattern on the bases of the kinetic constants of the transferases, that were estimated from the steady state concentrations of the glycolipid substrates in intact cells [210]. Contradictory results have been reported on the subcellular localization of the glycosyltransferases involved in the biosynthesis of ganglioseries gangliosides [211]. An additional feature of ganglioside biosynthesis and its regulation [212] is the formation of functional complexes, as predicted by Roseman [213]. In these complexes [140], the glycosyltransferases do not only form functional platforms, but can also show altered activity and suborganellar localization [214]. One of these complexes characterized in certain $\mathrm{CHO}$ cells [215] comprises B4GalNT I and B3GalT IV (Figure 12), so that it can accept GM3 and release GM1. This might explain why the brain contains large amounts of GM1 and GD1a, but little GM2. Also GalT I, ST3Gal V, and ST8Sia I can form such a complex [216].

\section{Degradation}

6.1. General. The constitutive degradation of gangliosides takes place in endosomes and lysosomes. In addition, also the plasma membrane-associated sialidase Neu3 [217, 218] can degrade gangliosides and is, for example, highly expressed on melanoma cells [219]. Even the nuclear envelope contains sialidases, with Neu3 in the inner and Neu1 in the outer nuclear membrane [220]. Lysosomal ganglioside degradation takes place after the endocytosis of parts of the plasma membrane at intraendosomal and intralysosomal membranes and related lipid aggregates. This requires the presence of suitable glycosidases [221], of an appropriate $\mathrm{pH}$, in some cases also of lipid-transfer proteins, and of an appropriate composition of the ganglioside-containing membranes [222].

As proposed in 1992, two different membrane pools are present in endosomes and lysosomes [223] (Figure 15). They differ in lipid- and protein composition and function. While the luminal membrane pool that is derived from the plasma membrane or by autophagy is degraded, the perimeter membrane (Figure 15) is protected from degradation by various means [224]. This ensures the integrity of the compartment, which can be abolished during apoptosis [224]. A marker lipid that is exclusively found in luminal membranes [225] is bis(monoacylglycero)phosphate (BMP; Figure 14), chemically incorrect also named as lysobisphosphatidic acid
(LBPA). BMP plays a key role for membrane degradation [226] and is formed from phosphatidylglycerol [227]. Due to its $s n 1, s n 1^{\prime}$ configuration, it is only slowly degraded by lipases and persists on inner membranes, in which it can amount up to $70 \%$ of total phospholipids [228]. With a predicted $\mathrm{p} K_{A}$ value of about $2, \mathrm{BMP}$ is negatively charged even at lysosomal $\mathrm{pH}$. In vitro studies show that negatively charged lipids are required for binding of lysosomal proteins to membranes. Although other negatively charged lipids such as dolichol phosphate or phosphatidylinositol can be present on luminal membranes, BMP appears to be the key factor that distinguishes this membrane pool from the perimeter membrane. On the other hand, the perimeter membrane of endosomes and lysosomes shows an entirely different lipid and protein composition. It is protected by a glycocalyx formed by highly $N$-glycosylated integral membrane proteins $[229,230]$, and ganglioside GM3 present in this membrane is resistant to degradation [231].

Ganglioside degradation starts with the action of glycosidases that cleave off monosaccharide units from the non-reducing end of the ganglioside glycan chains. This happens in a sequential manner, which explains the different human diseases that are associated with defects in this pathway. The glycosidases are soluble enzymes in the lumen of endosomes and lysosomes. It turned out that their activity is not sufficient towards GSL substrates with cleavage sites in proximity to the intralysosomal membrane surface. Although also other factors play a role, this can be attributed to steric hindrance by adjacent membrane components that impede the access of the soluble enzyme. For example, in wild-type and GM2-activator deficient fibroblasts, radiolabelled GD1aGalNAc (Figure 3), which has the same terminal trisaccharide as GM2, is degraded in the absence of the GM2-activator protein, while the degradation of GM2 itself is strictly dependent on the presence of the activator [232]. As glycosidase substrates, GSLs with four carbohydrate residues or less require the additional presence of small lipid binding glycoproteins, either the GM2 activator protein or one of the four saposins A-D. These act in part as lipid-transfer proteins that extract the membrane-bound substrates and present them to the hydrolases. They have different specificities and mechanisms of action [233]. In the case of gangliosides, at least the GM2-activator protein and saposin-B participate in the degradation of GM1, GM2, and GM3 (Figure 16).

In vitro, in addition to enzymes and activator proteins, also an appropriate membrane-lipid composition of the ganglioside-containing membrane is required for degradation [222]. Saposin-A [234] and saposin-B [235] extract membrane lipids much better from membranes that are rich in BMP and poor in cholesterol. BMP also increases the ability of the GM2 activator to solubilize lipids [236] and stimulates the hydrolysis of membrane-bound GM1 by GM1 $\beta$-galactosidase [237] and of ganglioside GM2 by $\beta$-hexosaminidase A [236]. BMP also stimulates hydrolysis of the kidney sulfatide with ganglio-series GSL-core SM2 (gangliotriaosylceramide- $\mathrm{II}^{3}$ sulfate) by $\beta$-hexosaminidases $A$ and $S$ in the presence of the GM2 activator $[238,239]$. Cholesterol, which is known to stabilize lipid bilayers, 


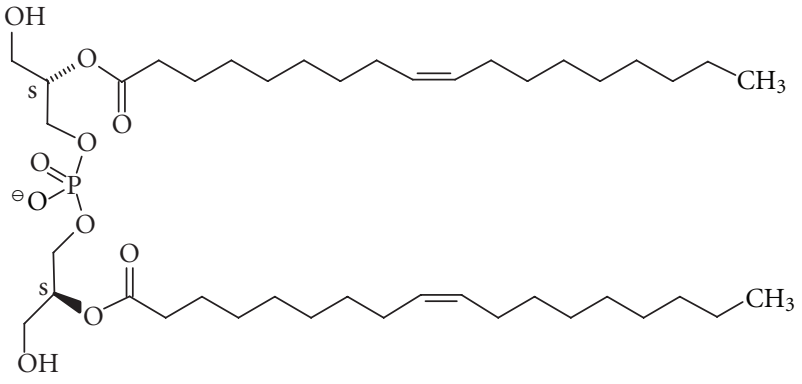

Figure 14: Bis(monoacylglycero)phosphate with two oleic acid moieties.

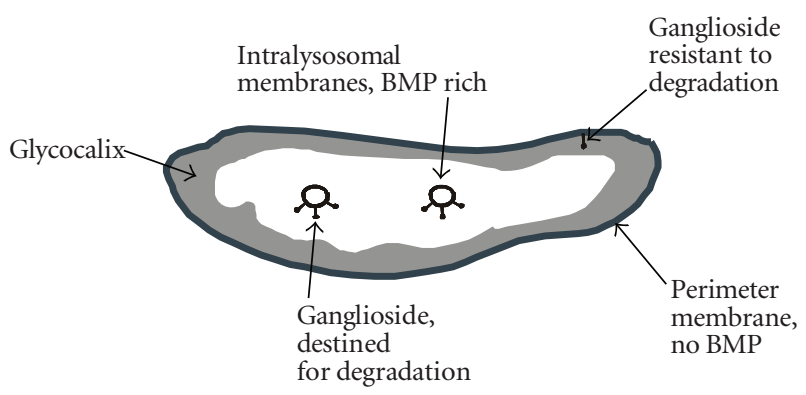

FIGURE 15: Lysosomal membrane pools.

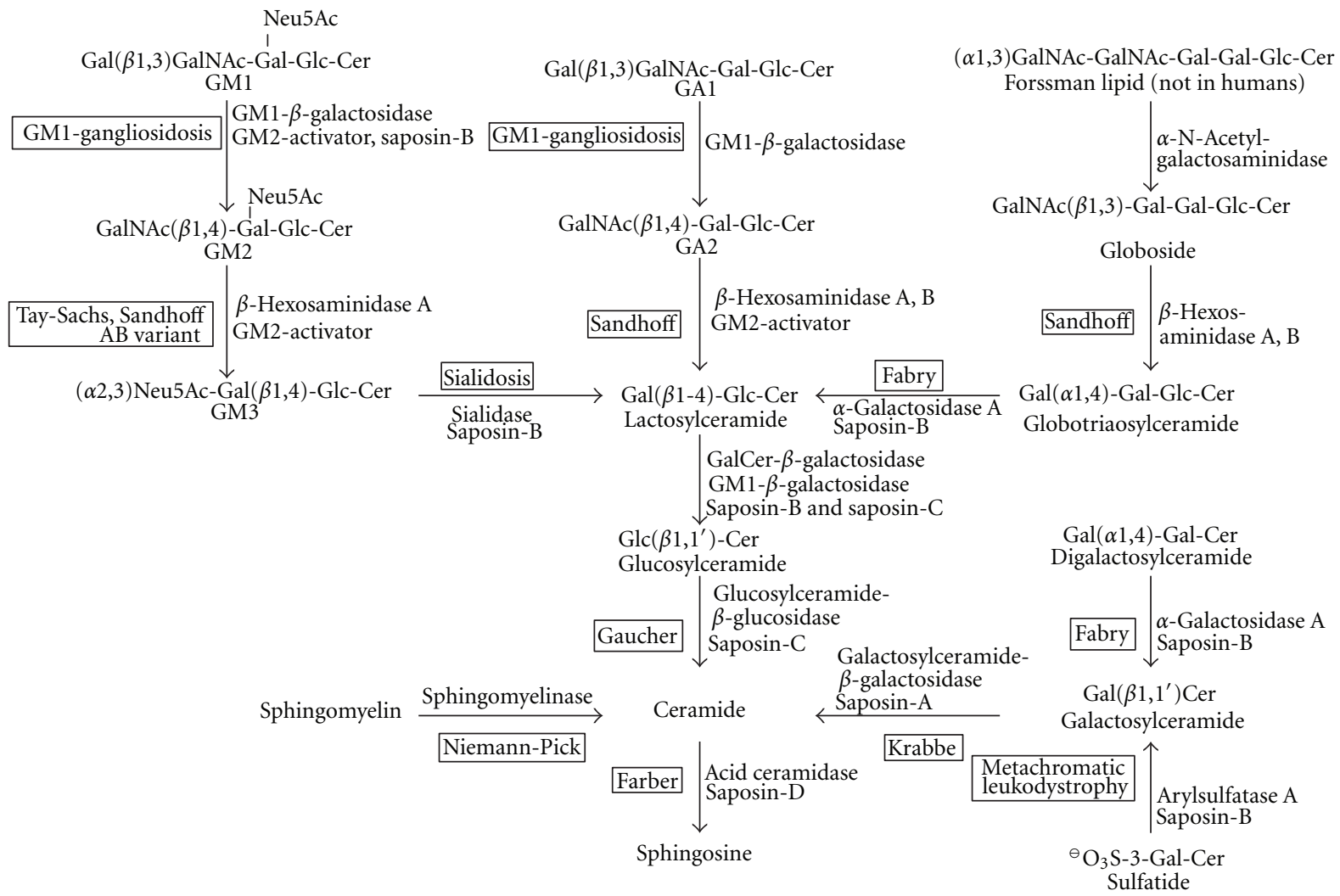

Figure 16: Lysosomal ganglioside degradation pathway (modified from [233]). Names of inherited diseases (in boxes), enzymes, and lipidtransfer proteins required in vivo are given. 
has to be transported from intraendosomal membranes to the NPC1 protein resident in the endosomal perimeter membrane by the soluble lipid-transfer protein NPC2. In vitro, this transfer is greatly stimulated by BMP and strongly inhibited by sphingomyelin [240].

\subsection{Selected Key Proteins for Ganglioside Degradation}

6.2.1. Saposin-B. Saposins are small, water-soluble lysosomal lipid-binding and -transfer proteins of about 8$11 \mathrm{kDa}$ molecular weight. They are derived from a common precursor protein, prosaposin, by proteolytic processing. Saposins belong to a family of proteins with conserved three-dimensional fold [241] and occur as homo- and heterodimers and -oligomers. The first saposin has been characterized in 1964 as the so-called sulfatide activator since it enables the degradation of sulfatide by arylsulfatase A [242]. Today this protein is known as saposin-B or sap-B. Saposin-B has many functions: it is a lipid-binding protein with broad specificity [243] and forms water-soluble lipidprotein complexes [244]. With respect to gangliosides, it is able to stimulate the degradation of ganglioside GM1 by GM1- $\beta$-galactosidase [237]. Studies in cultured human skin fibroblast derived from saposin-B and prosaposin-deficient patients show that it is also required for the degradation of GM3 [245, 246]. It is important to note that glycosylation of saposin-B is essential for some of its functions and that human patients without this postranslational modification die, although the unglycosylated variant protein is present in lysosomes [235].

Mechanistically, saposin-B dimers seem to act similar to the GM2 activator: X-ray data indicate that they can adopt two conformations, an open one and a closed one [247]. According to a model view, the open conformation interacts directly with the membrane and extracts the lipid ligand. This is accompanied by a change to the closed conformation in which the ligand is exposed to the degrading enzyme in a water-soluble activator-lipid complex. Human patients with an inherited deficiency of saposin-B develop an atypical form of metachromatic leukodystrophy with the accumulation of sulfatides, digalactosylceramide, and globotriaosylceramide [248] (see Figure 16 for structures). Saposin-B knockout mice show enhanced levels of sulfatides especially in brain and kidney [249].

6.2.2. The GM2 Activator. The GM2 activator is a small glycoprotein of $17.6 \mathrm{kDa}$ in its deglycosylated form and is required for the degradation of ganglioside GM2 by $\beta$ hexosaminidase A in vivo [250]. Inherited deficiency of the GM2-activator protein leads to the $\mathrm{AB}$ variant of GM2 gangliosidoses [251]. Based on the X-ray structure $[252,253]$ and data from photoaffinity labeling [254], in some respects the GM2-activator acts in a way similar to saposin-B. A more detailed picture of the binding mode was derived from binding studies using a spin-labelled GM2 activator to phosphatidylcholine bilayers [255]. The protein can extract a variety of lipids, which has been exploited for assay development [256]. However, its major function is to form a water-soluble GM2-protein complex that is the native Michaelis-Menten substrate of $\beta$-hexosaminidase A [250]. Negatively charged lipids such as BMP, dolichol phosphate, or phosphatidylinositol increase the extraction efficiency towards GM2 [236], GM1 [237], and other lipids [257] from liposomal membranes. Binding characteristics of the GM2 activator are altered by the presence of a His tag [257].

In Langmuir experiments, the GM2-activator protein is able to penetrate into a phospholipid monolayer, but only when the lateral pressure is below a critical value, which depend on the lipid composition and is in the range from 15 to $25 \mathrm{mN} / \mathrm{m}$ [258]. In addition to its function as a ganglioside-transfer protein, the GM2 activator binds also other lipids like phosphatidylcholine [259] and platelet activating factor (PAF) and inhibits its action [260, 261]. It is not clear whether the GM2 activator displays inherent hydrolytic activity towards lipid substrates such as platelet activating factor [262] or phosphatidylcholine [259]. Apparently unrelated to its GM2 transfer property is the function of the GM2 activator as adipokine [263]. GM2activator orthologs might serve different functions in other organisms, for example as a pheromone-binding protein in Drosophila [264], or an inhibitor of PAF-induced chemotaxis in nematodes [265].

The saposins and the GM2-activator play major roles in the transfer of lipid antigens to membrane-resident CD1proteins $[266,267]$.

6.2.3. Proteins Required for GM1 Degradation. GM1- $\beta$-galactosidase is a protein of $64 \mathrm{kDa}$, which is derived from an $88-\mathrm{kDa}$ precursor $[268,269]$. An alternatively spliced, enzymatically inactive $\beta$-galactosidase form of $67 \mathrm{kDa}$ is an elastin/laminin-binding protein [270]. GM1- $\beta$-galactosidase is part of a lysosomal multienzyme complex, together with the so-called protective protein (carboxypeptidase A), sialidase, and $N$-acetylaminogalactose-6-sulfate sulfatase [271]. GM1- $\beta$-galactosidase catalyzes the hydrolytic cleavage of several $\beta$-galactosides. The hydrolysis of ganglioside GM1 to GM2 requires the presence of either the GM2-activator protein, or saposin-B [56], or, in vitro, of an appropriate detergent.

6.2.4. Proteins Required for GM2 Degradation. GM2 is degraded by the cleavage of the $N$-acetylgalactosaminyl residue by $\beta$-hexosaminidases. In mice, the substrate specificity of the murine lysosomal sialidase allows for a significant cleavage also of the sialic moiety in GM2 (to yield GA2) [272]. Cleavage of the GalNAc residue requires the presence of the GM2-activator protein in vivo, or of an appropriate detergent in vitro. Three gene products participate in GM2 hydrolysis, the $\beta$-hexosaminidase $\alpha$ - and $\beta$-chains, and the GM2-activator protein. $\beta$-Hexosaminidases are dimers that result from the combination of their $\alpha$ - and $\beta$-subunits and differ in properties such as stability and substrate specificity. $\beta$-Hexosaminidase A with subunit composition $\alpha, \beta$ cleaves terminal $\beta$-glycosidically linked $N$-acetyl-glucosamine and $N$-acetylgalactosamine residues from negatively charged and uncharged glycoconjugates by a retaining doubledisplacement mechanism. The enzyme has two active sites, 
one on the $\alpha$-chain and the other on the $\beta$-chain [273]. $\beta$ Hexosaminidase $\mathrm{B}(\beta \beta)[274,275]$ predominantly cleaves uncharged substrates such as GA2 and oligosaccharides with terminal $N$-acetyl-hexosamine residues (see also Figure 16). $\beta$-Hexosaminidase $S(\alpha \alpha)$ is thermolabile and of secondary significance for GM2 degradation, but it contributes to the degradation of glycosaminoglycans and sulfated glycolipids [238].

\section{Pathobiochemistry}

Defects in enzymes and other proteins required for lysosomal degradation of complex lipids and of oligomeric or polymeric biomolecules lead to inherited diseases, the lysosomal storage diseases [276]. They can be classified according to the stored substances, as sphingolipidoses [277], mucopolysaccharidoses, mucolipidoses, glycoprotein-, and glycogen-storage diseases [278, 279]. Ganglioside degradation is impaired in the gangliosidoses and secondarily also in other sphingolipid storage diseases [280]. The principles [281] governing pathogenesis [282, 283] and therapy of sphingolipidoses [284] are also valid for the ganglioside storage diseases.

Key factors are the residual activity of the degrading system, which determines the course of the disease [285, 286], and the cell-type-specific expression of storage material. Due to the cell-type-specific expression of gangliosides, the central nervous system is especially affected in the gangliosidoses. In sphingolipidoses in general, the storage lipids coprecipitate other hydrophobic substances present in the endolysosomal compartment, lipids and proteins, as secondary storage products [280]. In Niemann-Pick disease, type C, which is a primary defect of endosomal cholesterol transport, a secondary accumulation of sphingomyelin (therefore the name Niemann-Pick) and of gangliosides is observed that is also of therapeutic relevance [287, 288]; for a remarkable treatment of Niemann Pick C1 fibroblasts with a histone deacetylase inhibitor, compare [289]. Secondary storage of gangliosides GM2 and GM3 occurs also in Hurler disease [290] (mucopolysaccharidosis type I; $\alpha$-Liduronidase deficiency). Lipid storage produces a kind of traffic jam [291, 292], which interferes with lipid transport and lysosomal function. Primary and secondary storages substances can impair nutrient delivery via the endolysosomal system: as demonstrated in mouse models of GM1 gangliosidoses and in a variant form of the GM2 gangliosidoses, Sandhoff disease, iron homeostasis is impaired in the animals, and supplementation of the animals with iron ions increased their life expectancy by nearly 40\% [293]. Since also autophagy can be impaired in lysosomal storage diseases [294], both pathways may lead to a shortage of nutrients.

Ganglioside degradation is impaired in the gangliosidoses. In another disease, galactosialidosis, the primary defect of carboxypeptidase A (protective protein), leads to a secondary loss of $\beta$-galactosidase and sialidase Neu1 accompanied by GM1 storage [271]. Gangliosidoses are caused by defects in the genes encoding glycosidases or lipidtransfer proteins that are required for lysosomal ganglioside degradation. The theoretical basis for the therapeutic approaches towards gangliosidoses is the "threshold theory" [286], which predicts that the ratio of substrate influx into the lysosomes and the degradation capacity determine the course of the diseases. Both parameters can be addressed by different therapeutic approaches [281].

7.1. GM1 Gangliosidosis. GM1 gangliosidosis is caused by an inherited deficiency of GM1- $\beta$-galactosidase (acid $\beta$ galactosidase; GLB1; EC3.2.1.23) [295]. After the description of the first patients [296] it became also known as Landing diseases [297]. It is a rare disease with an autosomal recessive mode of inheritance and characterized by the accumulation of GM1 and GA1 (Figure 16) in neuronal cells [12]. According to the substrate specificity of the variant enzyme in the patients, an inherited defect of the $\beta$-galactosidase can also lead to another disease, Morquio disease, type B. Three clinical forms of GM1 gangliosidosis can be distinguished, infantile (type 1) GM1 gangliosidosis with the developmental arrest and progressive deterioration of the nervous system in early infancy and a life expectancy of about 2 years, late infantile/juvenile form (type 2), and an adult/chronic form (type 3). Dysmorphic changes characteristic for Morquio disease type B are less prominent or completely absent in these clinical forms.

In addition to GM1, other enzyme substrates accumulate, such as GA1 (Figure 16) [12], oligosaccharides from glycoproteins, and intermediates of keratin sulfate degradation [268]. These substances are stored in different organs, according to their major site of biosynthesis. Lysosomal GM1 accumulation in neurons leads to the degeneration of the nervous system. Like in other storage diseases, an inflammatory response [298], neurorestorative properties of excess ganglioside GM1 [299] in the plasma membrane, and an unfolded protein response [300] contribute to pathogenesis. Such as in other sphingolipidoses [281], severity and progression of the disease correlate with the residual enzymatic activity in cells and body fluids.

Morquio type B disease clinically resembles a mild phenotype of Morquio A disease, where keratan sulfate accumulates due to $N$-acetyl-galactosamine-6-sulfatase deficiency. Like GM1 gangliosidosis, Morquio type B is due to the inherited defect of GM1- $\beta$-galactosidase. It is characterized by the predominant storage of keratan sulfate and oligosaccharides with terminal $\beta$-galactosyl residues. Patients show generalized skeletal dysplasia without involvement of the nervous system and without hepatosplenomegaly; for a clinical description, compare [268]. Differences between GM1 gangliosidosis and Morquio B disease can be attributed to a lower affinity and activity of $\beta$-galactosidase variants towards substrates with Gal- $\beta 1,4-$ GlcNAc motifs in Morquio patients compared to the Gal- $\beta 1,3-G a l N A c$ motive present in ganglioside GM1 [301]. There is no causal therapy available for GM1-gangliosidosis; however, progress is made towards the development of pharmacological chaperones also for this lysosomal disease [302-304].

7.2. GM2-Gangliosidoses. The GM2-Gangliosidoses are caused by defects in degradation of ganglioside GM2 [305]. 
The three variant forms of the GM2-gangliosidoses are named according to the hexosaminidase isoenzyme that remains intact. The B-variant, in its infantile course better known as Tay-Sachs disease, is caused by the deficiency of hexosaminidases $\mathrm{A}$ and $\mathrm{S}$, but with normal hexosaminidase B. The 0 variant, or Sandhoff disease, is caused by the deficiency of the $\beta$-chain and the resulting deficient activity of $\beta$-hexosaminidases $A$ and $B$ (therefore, none of the major enzymes is intact), however with the remaining activity of $\beta$-hexosaminidase $\mathrm{S}$. The $\mathrm{AB}$-variant $-\beta$-hexosaminidases $A$ and $B$ (and S) intact-results from mutations in the GM2-activator gene; so that tissue samples from the patients are able to degrade GM2 in detergent-containing enzyme assays.

7.2.1. Tay-Sachs Disease. Clinically, the B variant of GM2 gangliosidoses can be subclassified into infantile, juvenile, chronic, and adult onset forms. The infantile form, TaySachs disease, has a higher prevalence among Ashkenazi Jews with a heterozygote frequency of $1: 27$. Affected children are normal at birth and show first symptoms, such as mild motor weakness, a cherry red spot in the central retina, and increased startle reaction between 3 and 6 months of life. Progressive deterioration with weakness, hypotonia, or poor head control leads to a vegetative state and death often between the second and fourth year of life. Juvenile and adult course is observed in patients with a higher residual activity of the variant hexosaminidase A [285]. Symptoms are very heterogeneous; for a clinical description, compare [305].

The B1 variant of GM2 gangliosidoses [309, 310] was very difficult to elucidate: synthetic uncharged substrates used for diagnosis such as MufGlcNAc (Figure 17; for kinetic parameters see [311]) were cleaved, suggesting the presence of $\beta$-hexosaminidase, and also the GM2 activator was present. As it turned out, the B1 variant differs enzymatically from the $B$ variant by an altered substrate specificity of the variant $\beta$-hexosaminidase $A$. While uncharged substrates are cleaved, no activity is detected towards GM2 and towards sulfated, negatively charged [312] synthetic fluorogenic substrates. In the $\mathrm{B} 1$ variant, the function of the $\alpha$-chain active site is defective, but subunit association, enzyme processing, and the activity of the $\beta$-chain are not impaired. Homozygous patients with the B1 mutation show the course of the juvenile disease; compound heterozygotes with a B1 and a null allele show a late infantile course.

7.2.2. Sandhoff Disease. The 0 variant of GM2 gangliosidosis was the first gangliosidosis for which the underlying enzymatic defect was identified [14]. Due to the deficiency of two enzyme activities, $\beta$-hexosaminidases $\mathrm{A}$ and $\mathrm{B}$, storage of negatively charged glycolipids characteristic for Tay-Sachs disease and, in addition, of uncharged substrates such as GA2 in the brain and globoside in visceral organs (Figure 16) is observed. In infantile Sandhoff disease, patients show clinical and pathological manifestations of Tay-Sachs disease (infantile B variant) and in addition also organomegaly and slight bone deformations. For further symptoms and the description of juvenile and adult forms, compare [305].
7.2.3. AB Variant of GM2 Gangliosidosis. The AB variant is due to the deficiency of the GM2-activator protein [251], with intact $\beta$-hexosaminidases $\mathrm{A}$ and $\mathrm{B}$ (and $\mathrm{S}$ ), therefore the name. The disease is characterized by accumulation of GM2 and GA2 (for structures, see Figure 16). The clinical picture [305] resembles that of Tay-Sachs disease with a delayed appearance of symptoms; an animal model is available [313].

7.2.4. Pathogenesis and Therapy. Although lysosomal GM2 as the major storage compound in GM2 gangliosidoses is neither toxic nor immunogenic, its accumulation induces inflammatory responses as demonstrated for glycoconjugates in the murine model of Sandhoff disease [108]. Huge axon hillock enlargements, the so-called meganeurites, have been observed in neurons of patients with different lysosomal storage diseases, which might be attributed to the storage substance GM2 and contribute to synaptic dysfunction [314]. As in other sphingolipidoses [281], the corresponding (more toxic) lysolipid, in this case lysoGM2 (Figure 18), is elevated $[315,316]$ and contributes to the pathogenesis. LysoGM2 has been suggested as a biomarker for TaySachs and Sandhoff disease [317]; for occurrence and role of lysoGSLs in acquired diseases, compare [318]. Despite naturally occurring animal models of GM2 gangliosidoses in dogs, cats, and pig, murine models are used for therapy studies. Since the mouse model of Tay-Sachs disease is largely asymptomatic, the mouse model of Sandhoff disease is used for most studies [272].

Despite some success in the experimental treatment of juvenile and adult patients as well as in the animal models, there is no causal therapy available for the severe forms of the GM2 gangliosidoses. The limitations of the substrate reduction approach, which reduces the GM2 influx into the lysosomal compartment, have been evaluated by a genetic experiment: Sandhoff-disease mice were crossbred with mice defective in GM2 synthase. The lifespan of these animals was much longer than that of Sandhoff-disease mice, but instead of GM2 storage they developed a oligosaccharide storage, neurological disease [319].

Therapeutic approaches such as bone-marrow transplantation [320], enzyme-replacement therapy with recombinant highly phosphomannosylated $\beta$-hexosaminidase A [321], or transplantation of neural stem cells [322] have been investigated in the animal model of the 0 variant, substrate-reduction therapy with $N$-butyl deoxynojirimycin $[323,324]$, and with pyrimethamine as pharmacological chaperone $[325,326]$ in adult patients and gene therapy in endothelial cells [327]. Treatment of the accompanying inflammation is beneficial [328].

7.3. Selected Other Aspects. In addition to inherited diseases, ganglioside levels can also be altered in several acquired diseases [318]. For example, gangliosides play roles in neurological diseases such as Alzheimer's [329], Parkinson, or Huntington's disease [330]. In cancer, ganglioside expression can also be altered in tumor cells with an impact on signalling and tumor-host interactions [331]. [Neu5Gc] GM3 [332], GD2, GD3, GM2, and fucosylGM1 are regarded as 


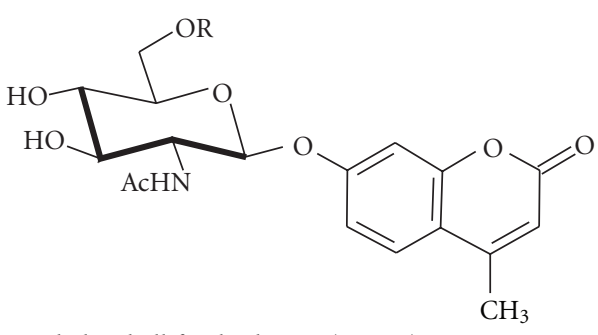

Methylumbelliferyl-GlcNAc $(\mathrm{R}=\mathrm{H})$

Methylumbelliferyl-GlcNAc-6-sulfate $\left(\mathrm{R}=\mathrm{SO}_{3}{ }^{\ominus}\right)$

Figure 17: Synthetic substrates for the determination of $\beta$-hexosaminidas-e $\mathrm{A}\left(\mathrm{R}=\mathrm{SO}_{3}{ }^{-}\right)$and $\beta$-hexosaminidases $\mathrm{A}+\mathrm{B}(\mathrm{R}=\mathrm{H})$.

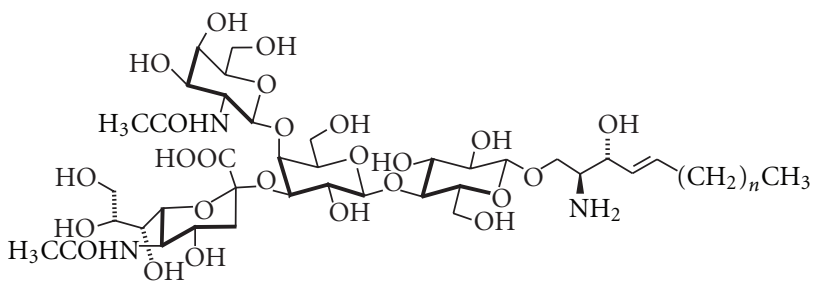

Figure 18: LysoGM2 $(n=12,14)$.

tumor-associated antigens [333] and are targets for the immunotherapy of cancer [334].

Also several neuropathies including variant forms of Guillain-Barré and Miller-Fisher syndrome are caused by serum antibodies against gangliosides [335].

There are only a few therapeutic roles for gangliosides, especially since they can induce neuropathies. In the past, gangliosides isolated from bovine brain have been investigated and also applied to human patients to improve neural repair and for the treatment of stroke [336, 337]. Also the direct application of ganglioside GM1 into the brain of patients with Alzheimer disease has been evaluated [338]. As indirect roles, the inhibition of ganglioside biosynthesis for the treatment of insulin resistance [339], the interference with microbial binding to gangliosides [340], or the reduction of neurotoxicity with Liga20 [341] has to be mentioned.

\section{Functional Aspects}

A plethora of functions has been attributed to gangliosides [342], for example, for GM3 [343], the most abundant ganglioside in most mammalian cell types, but not in neurons, or for GM1 [344]. In general, gangliosides mediate their function via interaction with soluble or membranebound binding molecules outside the cell ("trans" interaction), or by influencing properties of proteins within the same membrane ("cis" interaction) [32, 345-348]. "Trans" interactions occur between the glycan part of gangliosides on the one side with lectins on the other side. Also gangliosides contribute to the chemical high-density sugar code of cell surfaces [349]. For example, GM1 can be recognized by galectin-1 [350] and sialic acids in $\alpha 2,3$-linkage

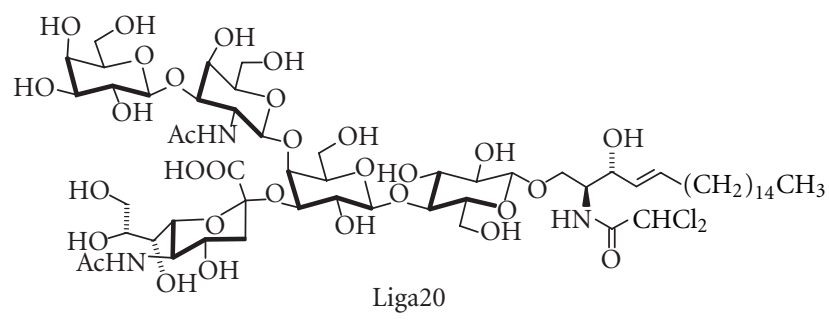

FIGURE 19: Structure of Liga20, a semitruncated and halogenated GM1 analog that can pass the blood-brain barrier.

are recognized by the sialic acid binding immunoglobulin lectins Siglec-4, $\alpha 2,6$-sialosides by Siglec-2, and $\alpha 2,8$ sialosides by Siglec-7 [347]. Also carbohydrate-carbohydrate interactions can play a role $[351,352]$. Although interactions between individual carbohydrate residues [353] are weak, clustering of gangliosides offer the possibility for multivalent interactions, if they are not buried under glycoprotein glycans. Apparently, GM3 on mouse melanoma B16 cells can mediate cell adhesion to mouse lymphoma L5178 cells by binding to GA2 (gangliotriaosylceramide, GalNAc $\beta 1,4 \mathrm{Gal} \beta 1,4 \mathrm{Glc} \beta 1,1 \mathrm{Cer}$; see Figure 12 or Figure 16) [354]. Within the nervous system, gangliosides act in a "trans" manner with the myelin-associated glycoprotein MAG. MAG recognizes NeuAc $\alpha 2-3 \mathrm{Gal} \beta 1-3$ GalNActermini on axonal gangliosides, an interaction that is essential for axon-myelin stability and axon regeneration [355].

"Cis" interactions can happen via a direct interaction, or, indirectly, via the properties of the membrane or of putative-membrane domains [356]. This way gangliosides influence the activities of receptor-tyrosine kinases in the plasma membrane, such as the receptors of epidermalgrowth factor, nerve growth factor, and insulin and therefore cell signaling [357]. For example, GM1 enhances TrkA neurotrophin receptor-activation in a "cis"-manner [358]; for a brief overview of proteins affected by certain gangliosides, compare, for example, [359]. Since the characterization of lipid microdomains in living cells is difficult, some conclusions can be drawn from in vitro experiments. For example, GM3 inhibits the autophosphorylation of purified EGFR reconstituted into the proteoliposomes of defined lipid compositions, but not the EGF binding [360]. There are indications that gangliosides may not act only in an autonomous manner, but might also support the formation of distinct membrane phases, although it is a matter of debate to which extent this operates in vivo. It is believed that gangliosides are not homogeneously distributed on the cell surface, but segregate into membrane domains together with GPI-anchored proteins, sphingomyelin and cholesterol. Such rafts have been supposed to be the physiological surroundings of many membrane proteins, although no rigid proof for their existence has been provided. Ganglioside plays a largely unexplored role for membrane structure [356]. Due to their large hydrated head groups, they stabilize membrane areas with positive curvature [361]. A multitude of reports propose a segregation of gangliosides and other GSLs with cholesterol and GPI-anchored proteins into the lipid platforms known 
as "rafts" in the membranes of living cells [362-365]. Since most of the applied methods (detergent extraction, antibody, and toxin staining) constitute a bias towards the formation of such domains [366], the existence, size, and lifetime of rafts are a matter of debate. From thermodynamic considerations, it is clear that procedures such as detergent extraction can (or have to) produce artificial results and are not suitable for raft characterization [367-370]. Although it has been demonstrated that the treatment of cellular membranes with detergents causes the redistribution of gangliosides and GPI-anchored proteins $[371,372]$, these techniques are still applied and not always critically examined. Experiments in living cells using STED microscopy [308] and other visualization techniques [373] point to an upper limit of lifetime and size of such domains in the range of $20 \mathrm{~ms}$ and $20 \mathrm{~nm}$.

In addition, sialic acids and oligosialic acids present on gangliosides can modulate membrane surface charge density, the $\mathrm{pH}$ at the membrane surface, and membrane potentials [374]. In planar lipid bilayers, ganglioside GD1a can increase the excitability of voltage-dependent sodium channels [375].

8.1. Infection. "Cis" and "trans" interactions of gangliosides play multiple roles in the immune system [376] and in infectious diseases [377, 378], where gangliosides act as cellular receptors and coreceptors for viruses, bacteria, and microbial toxins. The most prominent example is GM1 as the receptor for cholera toxin [379]; other examples are the toxin of Clostridium botulinum and the SabA adhesin of Helicobacter pylori [380] that bind to cell surface gangliosides of the host [381]. Binding of sialylated cell surface glycoconjugates to Siglecs [382] on white blood cells is used within innate and adaptive immune responses to distinguish between self and nonself and to dampen autoimmune responses [383]. Many pathogens use sialic acids on cell surface glycoconjugates for cellular entry, for example, periodontal pathogens [384]. Recent examples include ganglioside GT1b, which seems to be the host cell receptor for the Merkel cell polyomavirus [385]. This virus has been identified as the cause of Merkel cell carcinoma, an aggressive type of skin cancer. Also sialidase-insensitive rotaviruses recognize sialic acid, for example, on ganglioside GM1, which is not substrate of all sialidases due to its branched structure [386] and the glycan present in ganglioside GDla serves as host receptor for the adenoviruses that cause epidemic keratoconjunctivitis [387].

\section{Tools}

9.1. Loss of Function. Gangliosides are secondary gene products. Their function can be analyzed by knockout experiments, where in cells, tissues, or organisms their formation or degradation is interrupted by genomic, posttranscriptional, or chemical strategies. Especially valuable were genetically engineered mice with defects in ganglioside biosynthesis [388], which revealed, for example, a role of gangliosides in calcium homeostasis [389], neural repair [390], or neurological diseases [330]. Also investigations in human patients [277], genetically engineered mammals [391], and other organisms [392] allowed insight into various aspects of ganglioside metabolism and transport. Also mutant and silenced cells have been applied for functional studies. In vitro systems such as liposomes or planar monolayers allow investigations that are to difficult to be carried out in cells. For example, when GM3 is incorporated into liposomes, a phase separation into GM3-rich and GM3-poor phases occurs above a certain GM3 content [393]. This would fit to reports on GM3-enriched microdomains in living cells.

In experimental approaches, ganglioside biosynthesis can be modulated by inhibitors [394]. Also the enhancement of ganglioside biosynthesis can be used, for example, chemically, or by the introduction of glycosyltransferase encoding cDNA in cultured cells $[395,396]$. An enantiomer of the glucosylceramide synthase inhibitor D-threo-PDMP (PDMP = 1-phenyl-2-decanoylamino-3-morpholino-1-propanol), Lthreo-PDMP, acts as an enhancer of ganglioside biosynthesis by upregulating glycosyltransferases. This was accompanied by increased neurite outgrowth [397]. Additional possibilities are the generation of mutant cells, for example for GM2 synthase [398] or by posttranscriptional silencing like RNA interference. While even complex systems like cultured cells can survive without GSLs, they are required for the development of multicellular organisms [399].

9.2. Structurally Defined and Modified Gangliosides. Structurally homogenous gangliosides and ganglioside probes that are modified by isotopes, fluorescence, chemical reporter groups, photoaffinity, or affinity ligands are valuable tools for the analysis of ganglioside function, metabolism, and transport. These tools are available by total or partial chemical synthesis, or by biosynthetic incorporation of suitable-for example, photolabile $-N$-acylmannosamine precursors into gangliosides [400] using the methodology for biosynthetic sialic acid modification developed by Kayser et al. [401]. For enzymological, transport, and crosslinking studies, tritium and ${ }^{14} \mathrm{C}$ are incorporated into different positions of gangliosides, but also radioiodination is possible in the presence of aryl residues [402, 403].

Ganglioside total synthesis is a time-consuming and demanding task and usually performed only in specialized laboratories for examples, see $[49,50]$. It relies predominantly on the sequential glycosidation of a 3-O-protected azidosphingosine [404] with suitably protected and activated glycosyl donors. This includes the trichloroacetimidates [405] as well as methods for $\alpha$-selective sialylation reactions [406]. Also chemoenzymatic procedures have been developed, where different glycosidation steps are catalyzed by glycosyltransferases [407] or glycosidases [408], or where oligosaccharyl fluorides are coupled to native or fluorescent ceramide anchors using an engineered endoglycoceramidase (glycosynthase) [49, 409]. Ganglioside oligosaccharides, such as those of GM3, GM2, GM1, GD3, and GT3, can be produced by genetically engineered bacterial strains. For the biotechnological production of ganglioside head groups, lactose can be internalized in E. coli as a precursor to be used as acceptor for glycosyltransferases [410-415]. An application of the ganglioside biosynthetic machinery is the preparative production of neoglycolipids with ganglioside head groups 


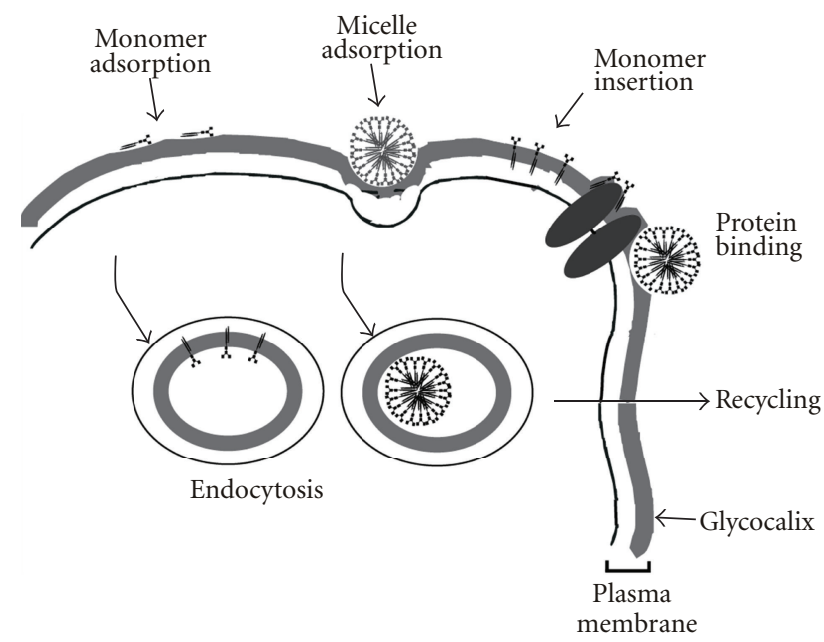

Figure 20: Schematic ganglioside uptake by cultured cells (modified from [306]).

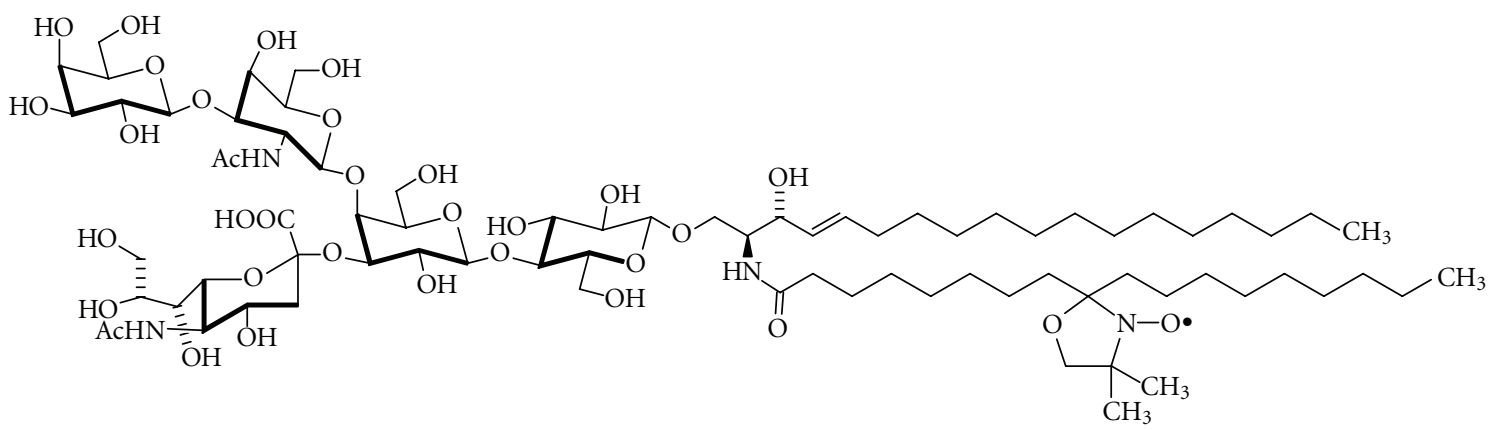

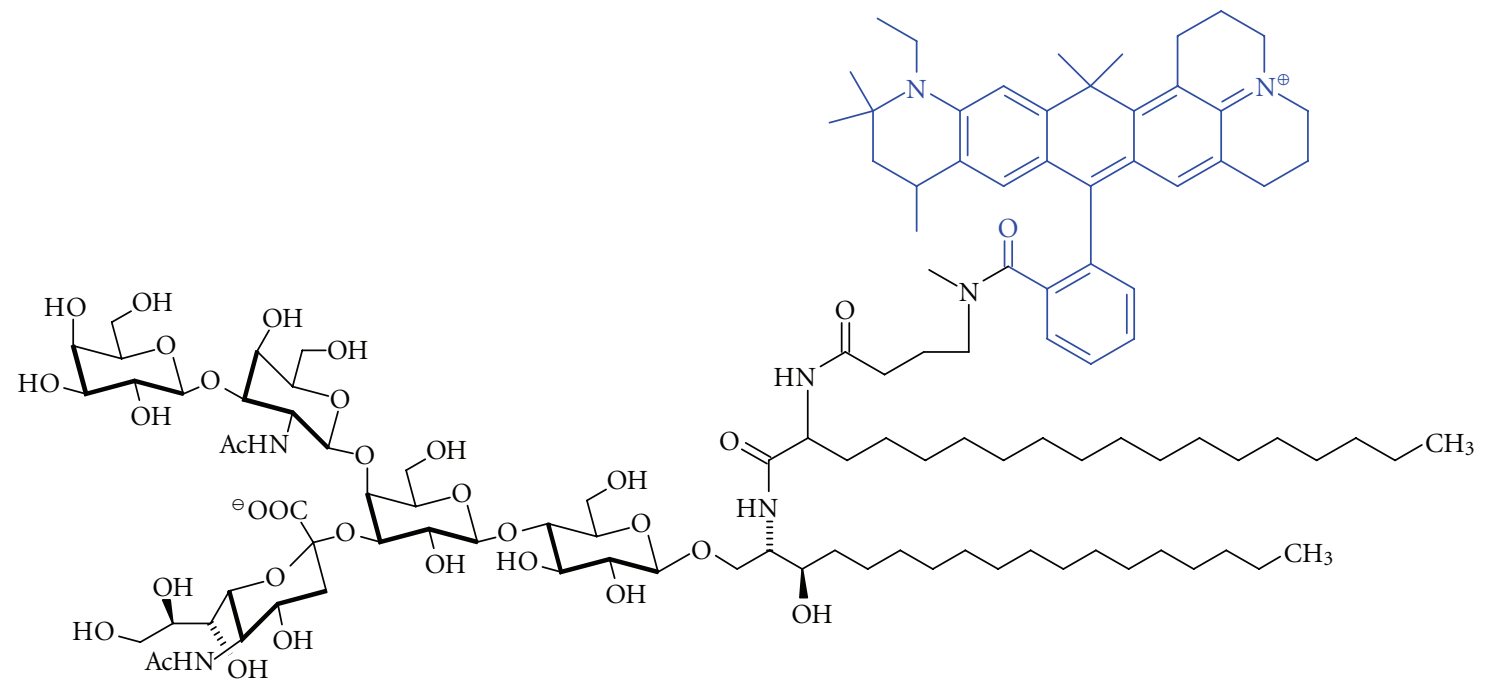

FIGURE 21: Example of a GM1 analog [307] spin labelled with a 4,4-dimethyl-oxazolidine-1-oxyl- (DOXYL-) residue and a fluorescent GM1 analog used for STED microscopy [308].

using a lung squamous-cell carcinoma line (RERF-LC-A) and 12-azidododecyl $\beta$-lactoside as a suitable primer [416].

GSLs isolated from natural sources can be used for the preparation of chemically modified derivatives [417] like labelled GSLs [418, 419], or those of enhanced metabolic stability [420]. The chemical release of the ganglioside glycan chain can be achieved by osmium tetroxide/periodate treatment of protected gangliosides [421, 422], or by ozonolysis of native gangliosides [423]. Initially, both methods give rise to ganglioside aldehydes, which are not isolated but subsequently fragmented by alkaline treatment, or, if desired, are isolated for further applications [424]. The glycan part 
can also be released enzymatically by ceramide glycanase $[425,426]$. Lysogangliosides that lack the acyl moiety at the sphingosine nitrogen can be prepared by chemical procedures $[427,428]$, or by enzymatic treatment of gangliosides with sphingolipid $N$-deacylase [429-431].

Lysogangliosides (see Figure 18) can be used for the introduction of fluorescence, spin, or radiolabels or other modifications into the lipid backbone of gangliosides. A semitruncated, dihalogenated GM1 analog that is able to pass the blood-brain barrier is Liga20 [398] (Figure 19). There are also several approaches to the synthesis of photoactivatable GSL derivatives [432].

It has to be noted that when gangliosides are added to the medium of cultured cells, they are largely present as oligomers in the form of micelles or vesicles, as monomers bound to proteins, and as free monomers. In aqueous surroundings, gangliosides form aggregates of different size and shape $[361,433]$. In most cases these are micellar structures of $280-630 \mathrm{kDa}$ [361], in the case of the gangliosides with small head groups, GM3 and GM4 also vesicles [361, 434, 435]. The critical micellar concentrations of GSLs are in the range of $10^{-9}-10^{-5} \mathrm{M}$ [436] and depend on temperature, $\mathrm{pH}$, and, in part, on the method of determination. Typical values are $3.4 \times 10^{-9} \mathrm{M}$ for GM3 to $3.9 \times 10^{-8} \mathrm{M}$ for GT1b [434].

Uptake of exogenously added gangliosides by cells in culture [437] can proceed in different ways $[306,420]$ (Figure 20). With the aid of radiolabelled [438] and spinlabelled gangliosides [307] (Figure 21), three modes of adherence have been distinguished: $60-90 \%$ of the exogenous ganglioside consist in loosely associated micelles and also monomers, which can be removed by delipidated serum proteins. A second fraction is attached to cellular proteins in a trypsin-labile fashion, and, finally, a trypsin-stable fraction is presumably inserted into the plasma membrane of the cell. Only the last fraction is in the topologically correct, native orientation. When bound to proteins, the offrate of gangliosides with native alkyl chain lengths can be very low. This is not the case for synthetic, semitruncated derivatives of higher solubility, which are frequently used, but show different intracellular transport behaviour compared to native gangliosides [420]. Fluorescently labelled glycosphingolipids [439] have been applied, but also their properties can differ significantly from the ones of native glycosphingolipids.

Gangliosides can also be transferred from cultured donor to acceptor cells that are separated by a membrane [440]. By this process known as "shedding" [441], tumor cells can release up to $0.5 \%$ of their gangliosides per hour [442].

Fluorescent ganglioside probes that bear the fluorophore in at the membrane-water interphase (Figure 21) behave physicochemically more like native gangliosides. Such compounds have been used as probes for STED microscopy [308] or to quantify the transfer capacity of GM2 activator in a liposomal FRET assay system [443].

\section{Conclusion}

Despite the fast development of analytical and biophysical tools, the analytical determination of ganglioside pattern, their spatial resolution, and their correlation with function is still a challenge. Especially a convincing characterization of ganglioside-containing membrane domains in living cells and of their roles at the cellular level would constitute a considerable advance in the field.

\section{Abbreviations}

\begin{tabular}{|c|c|}
\hline Cer: & Ceramide, N-Acylsphingosine \\
\hline GlcCer: & Glc $\beta 1 \mathrm{Cer}$ \\
\hline GalCer: & $\mathrm{Gal} \beta 1 \mathrm{Cer}$ \\
\hline Sulfatide: & Sulfate $3 \mathrm{Gal} \beta 1 \mathrm{Cer}\left(\mathrm{I}^{3}\right.$-sulfate, GalCer $)$ \\
\hline LacCer: & $\operatorname{Gal} \beta 1,4 \mathrm{Glc} \beta 1 \mathrm{Cer}$ \\
\hline GbOse3Cer: & Gal $\alpha 1,4 \mathrm{Gal} \beta 1,4 \mathrm{Glc} \beta 1 \mathrm{Cer}\left(\mathrm{Gb}_{3} \mathrm{Cer}\right)$ \\
\hline GbOse4Cer: & $\begin{array}{l}\text { GalNAc } \beta 1,3 \mathrm{Gal} \alpha 1,4 \mathrm{Gal} \beta 1,4 \mathrm{Glc} \beta 1 \mathrm{Cer} \\
\left(\mathrm{Gb}_{4} \mathrm{Cer}\right)\end{array}$ \\
\hline GA2: & GalNAc $\beta 1,4 \mathrm{Gal} \beta 1,4 \mathrm{Glc} \beta 1 \mathrm{Cer}\left(\mathrm{Gg}_{3}\right.$ Cer $)$ \\
\hline GA1: & $\begin{array}{l}\mathrm{Gal} \beta 1,3 \mathrm{GalNAc} \beta 1,4 \mathrm{Gal} \beta 1,4 \mathrm{Glc} \beta 1 \mathrm{Cer} \\
\left(\mathrm{Gg}_{4} \mathrm{Cer}\right)\end{array}$ \\
\hline GM1b: & $\begin{array}{l}\text { Neu } 5 \text { Ac } \alpha 2,3 \mathrm{Gal} \beta 1,3 \mathrm{GalNAc} \beta 1, \\
4 \mathrm{Gal} \beta 1,4 \mathrm{Glc} \beta 1 \mathrm{Cer}\left(\mathrm{IV}^{3} \mathrm{Neu} 5 \mathrm{AcGg}_{4} \mathrm{Cer}\right)\end{array}$ \\
\hline GD1c: & $\begin{array}{l}\text { Neu } 5 \text { Ac } \alpha 2,8 \text { Neu } 5 \text { Ac } \alpha 2,3 \mathrm{Gal} \beta 1 \\
3 \mathrm{GalNAc} \beta 1,4 \mathrm{Gal} \beta 1,4 \mathrm{Glc} \beta 1 \mathrm{Cer} \\
\left(\mathrm{IV}^{3}(\mathrm{Neu} 5 \mathrm{Ac})_{2} \mathrm{Gg}_{4} \mathrm{Cer}\right)\end{array}$ \\
\hline GD1 $\alpha:$ & $\begin{array}{l}\text { Neu5Ac } \alpha 2,3 \mathrm{Gal} \beta 1 \\
3(\mathrm{Neu} 5 \mathrm{Ac} \alpha 2,6) \mathrm{GalNAc} \beta 1, \\
4 \mathrm{Gal} \beta 1,4 \mathrm{Gl} / \beta 1 \mathrm{Cer} \\
\left(\mathrm{IV}^{3} \mathrm{Neu} 5 \mathrm{AcIII}{ }^{6} \mathrm{Neu} 5 \mathrm{AcGg}_{4} \mathrm{Cer}\right)\end{array}$ \\
\hline GM4: & $\begin{array}{l}\text { Neu5Ac } \alpha 2-3 \mathrm{Gal} \beta 1 \mathrm{Cer} \\
\left(\mathrm{I}^{3} \mathrm{Neu} 5 \mathrm{Ac} \alpha \mathrm{GalCer}\right)\end{array}$ \\
\hline GM3: & $\begin{array}{l}\text { Neu5Ac } \alpha 2,3 \mathrm{Gal} \beta 1,4 \mathrm{Glc} \beta 1 \mathrm{Cer} \\
\left(\mathrm{II}^{3} \text { Neu5AcLacCer) }\right.\end{array}$ \\
\hline GM2: & $\begin{array}{l}\text { GalNAc } \beta 1,4(\operatorname{Neu} 5 \mathrm{Ac} \alpha 2,3) \mathrm{Gal} \beta 1 \\
4 \mathrm{Glc} \beta 1 \mathrm{Cer}\left(\mathrm{II}^{3} \mathrm{Neu} 5 \mathrm{AcGg}_{3} \mathrm{Cer}\right)\end{array}$ \\
\hline GM1a: & $\begin{array}{l}\text { Gal } \beta 1,3 \mathrm{GalNAc} \beta 1 \\
4(\mathrm{Neu} 5 \mathrm{Ac} \alpha 2,3) \mathrm{Gal} \beta 1 \\
4 \mathrm{Glc} \beta 1 \mathrm{Cer}\left(\mathrm{II}^{3} \mathrm{Neu} 5 \mathrm{AcGg}_{4} \mathrm{Cer}\right)\end{array}$ \\
\hline GD1a: & $\begin{array}{l}\text { Neu5Ac } \alpha 2,3 \mathrm{Gal} \beta 1,3 \mathrm{GalNAc} \beta 1, \\
4(\mathrm{Neu} 5 \mathrm{Ac} \alpha 2,3) \mathrm{Gal} \beta 1,4 \mathrm{Glc} \beta 1 \mathrm{Cer} \\
\left(\mathrm{IV}^{3} \mathrm{Neu} 5 \mathrm{AcII}^{3} \mathrm{Neu} 5 \mathrm{AcGg}_{4} \mathrm{Cer}\right)\end{array}$ \\
\hline GT1a: & $\begin{array}{l}\text { Neu5Ac } \alpha 2,8 \mathrm{Neu} 5 \mathrm{Ac} \alpha 2,3 \mathrm{Gal} \beta 1, \\
3 \mathrm{GalNAc} \beta 1,4(\mathrm{Neu} 5 \mathrm{Ac} \alpha 2,3) \mathrm{Gal} \beta 1, \\
4 \mathrm{Glc} \beta 1 \mathrm{Cer} \\
\left(\mathrm{V}^{3}(\mathrm{Neu} 5 \mathrm{Ac})_{2} \mathrm{II}^{3} \mathrm{Neu} 5 \mathrm{AcGg}_{4} \mathrm{Cer}\right)\end{array}$ \\
\hline GT1 $\alpha$ : & 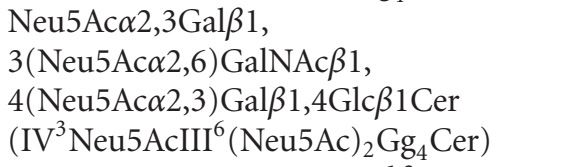 \\
\hline GD3: & $\begin{array}{l}\text { Neu5Ac } \alpha 2,8 \text { Neu5Ac } \alpha 2,3 \mathrm{Gal} \beta 1 \\
4 \mathrm{Glc} \beta 1 \mathrm{Cer}\left(\mathrm{II}^{3}(\mathrm{Neu} 5 \mathrm{Ac})_{2} \mathrm{LacCer}\right)\end{array}$ \\
\hline GD2: & $\begin{array}{l}\text { GalNAc } \beta 1, \\
4(\operatorname{Neu} 5 \mathrm{Ac} \alpha 2,8 \mathrm{Neu} 5 \mathrm{Ac} \alpha 2,3) \mathrm{Gal} \beta 1, \\
4 \mathrm{Glc} \beta 1 \mathrm{Cer}\left(\mathrm{II}^{3}(\mathrm{Neu} 5 \mathrm{Ac})_{2} \mathrm{Gg}_{3} \mathrm{Cer}\right)\end{array}$ \\
\hline GD1b: & $\begin{array}{l}\text { Gal } \beta 1,3 \mathrm{GalNAc} \beta 1, \\
4(\mathrm{Neu} 5 \mathrm{Ac} \alpha 2,8 \mathrm{Neu} 5 \mathrm{Ac} \alpha 2,3) \mathrm{Gal} \beta 1, \\
4 \mathrm{Glc} \beta 1 \mathrm{Cer}\left(\mathrm{II}^{3}(\mathrm{Neu} 5 \mathrm{Ac}){ }_{2} \mathrm{Gg}_{4} \mathrm{Cer}\right)\end{array}$ \\
\hline GT1b: & $\begin{array}{l}\text { Neu5Ac } \alpha 2,3 \mathrm{Gal} \beta 1,3 \mathrm{GalNAc} \beta 1 \\
4(\mathrm{Neu} 5 \mathrm{Ac} \alpha 2,8 \mathrm{Neu} 5 \mathrm{Ac} \alpha 2,3) \\
\text { Gal } \beta 1,4 \mathrm{Glc} \beta 1 \mathrm{Cer} \\
\left(\mathrm{IV}^{3} \mathrm{Neu} 5 \mathrm{AcII}^{3}(\mathrm{Neu} 5 \mathrm{Ac}){ }_{2} \mathrm{Gg}_{4} \mathrm{Cer}\right)\end{array}$ \\
\hline
\end{tabular}




\begin{tabular}{|c|c|}
\hline \multirow[t]{4}{*}{ GQ1b: } & $\begin{array}{l}\text { Neu5Ac } \alpha 2,8 \text { Neu } 5 \text { Ac } \alpha 2,3 \mathrm{Gal} \beta 1 \\
3 \mathrm{GalNAc} \beta 1\end{array}$ \\
\hline & 4(Neu5Ac $\alpha 2,8$ Neu5Ac $\alpha 2,3) \mathrm{Gal} \beta 1$ \\
\hline & $4 \mathrm{Glc} \beta 1 \mathrm{Cer}$ \\
\hline & $\left(\mathrm{IV}^{3}(\mathrm{Neu} 5 \mathrm{Ac})_{2} \mathrm{II}^{3}(\mathrm{Neu} 5 \mathrm{Ac})_{2} \mathrm{Gg}_{4} \mathrm{Cer}\right)$ \\
\hline \multirow[t]{5}{*}{ GQ1b $\alpha$ : } & $\operatorname{Neu} 5 \operatorname{Ac} \alpha 2,3 \mathrm{Gal} \beta 1$ \\
\hline & 3(Neu5Ac $\alpha 2,6)$ GalNAc $\beta 1$, \\
\hline & $4(\operatorname{Neu} 5 \mathrm{Ac} \alpha 2,8 \mathrm{Neu} 5 \mathrm{Ac} \alpha 2,3) \mathrm{Gal} \beta 1$ \\
\hline & $4 \mathrm{Glc} \beta 1 \mathrm{Cer}$ \\
\hline & $\left(\mathrm{IV}^{3}(\mathrm{Neu} 5 \mathrm{Ac})_{2} \mathrm{III}^{6}(\mathrm{Neu} 5 \mathrm{Ac})_{2} \mathrm{Gg}_{4} \mathrm{Cer}\right)$ \\
\hline GT3: & $\begin{array}{l}\text { Neu5Ac } \alpha 2,8 \text { Neu5Ac } \alpha 2,8 \text { Neu5Ac } \alpha 2 \\
3 \text { Gal } \beta 1,4 \text { Glc } \beta 1 \text { Cer }\left(\text { II }^{3}(\mathrm{NeuAc})_{3} \mathrm{LacCer}\right)\end{array}$ \\
\hline \multirow[t]{2}{*}{ GT2: } & GalNAc $\beta 1,4($ Neu 5 Ac $\alpha 2,8$ Neu 5 Ac $\alpha 2$ \\
\hline & $4 \mathrm{Glc} \beta 1 \mathrm{Cer}\left(\mathrm{II}^{3}(\mathrm{NeuAc})-\mathrm{Gg}_{3} \mathrm{Cer}\right)$ \\
\hline \multirow[t]{4}{*}{ GT1c: } & $\operatorname{Gal} \beta 1,3 \mathrm{GalNAc} \beta 1$ \\
\hline & $4($ Neu 5 Ac $\alpha 2,8$ Neu 5 Ac $\alpha 2$, \\
\hline & $8 \mathrm{Neu} 5 \mathrm{Ac} \alpha 2,3) \mathrm{Gal} \beta 1$ \\
\hline & $4 \mathrm{Glc} \beta 1 \mathrm{Cer}\left(\mathrm{II}^{3}(\mathrm{Neu} 5 \mathrm{Ac})_{3} \mathrm{Gg}_{4} \mathrm{Cer}\right)$ \\
\hline \multirow[t]{5}{*}{ GQ1c: } & Neu5Ac $\alpha 2,3 \mathrm{Gal} \beta 1,3 \mathrm{GalNAc} \beta 1$ \\
\hline & $4(\mathrm{Neu} 5 \mathrm{Ac} \alpha 2,8 \mathrm{Neu} 5 \mathrm{Ac} \alpha 2$ \\
\hline & 8 Neu5Ac $\alpha 2,3) \mathrm{Gal} \beta 1$ \\
\hline & $4 \mathrm{Glc} \beta 1 \mathrm{Cer}$ \\
\hline & $\left(\mathrm{IV}^{3} \mathrm{Neu} 5 \mathrm{AcII}^{3}(\mathrm{Neu} 5 \mathrm{Ac})_{3} \mathrm{Gg}_{4} \mathrm{Cer}\right)$ \\
\hline \multirow[t]{4}{*}{ GP1c: } & Neu5Ac $\alpha 2,8$ Neu 5 Ac $\alpha 2,3 \mathrm{Gal} \beta 1$ \\
\hline & 3GalNAc $\beta 1,4($ Neu 5 Ac $\alpha 2,8$ Neu 5 Ac $\alpha 2$, \\
\hline & $8 \mathrm{Neu} 5 \mathrm{Ac} \alpha 2,3) \mathrm{Gal} \beta 1,4 \mathrm{Glc} \beta 1 \mathrm{Cer}$ \\
\hline & $\left(\mathrm{IV}^{3}(\mathrm{Neu} 5 \mathrm{Ac})_{2} \mathrm{II}^{3}(\mathrm{Neu} 5 \mathrm{Ac})_{3} \mathrm{Gg}_{4} \mathrm{Cer}\right)$ \\
\hline \multirow[t]{6}{*}{ GP1c $\alpha$ : } & $\operatorname{Neu} 5 \mathrm{Ac} \alpha 2,3 \mathrm{Gal} \beta 1$ \\
\hline & 3(Neu5Ac $\alpha 2,6)$ GalNAc $\beta 1$, \\
\hline & $4(\mathrm{Neu} 5 \mathrm{Ac} \alpha 2,8 \mathrm{Neu} 5 \mathrm{Ac} \alpha 2$ \\
\hline & $8 \mathrm{Neu} 5 \mathrm{Ac} \alpha 2,3) \mathrm{Gal} \beta 1,4 \mathrm{Glc} \beta 1 \mathrm{Cer}$ \\
\hline & $\left(\right.$ IV $^{3} \mathrm{Neu} 5 \mathrm{AcIII}{ }^{6} \mathrm{Neu} 5 \mathrm{Ac}$ \\
\hline & $\left.\mathrm{II}^{3}(\mathrm{Neu} 5 \mathrm{Ac})_{3} \mathrm{Gg}_{4} \mathrm{Cer}\right)$ \\
\hline GD1b-lactone: & $\mathrm{II}^{3}[\mathrm{Neu} 5 \mathrm{Ac}-(2-8,1-9)-\mathrm{Neu} 5 \mathrm{Ac}] \mathrm{Gg}_{4} \mathrm{Cer}$ \\
\hline GalNAc-GD1a: & GalNAc $\beta 1,4 \mathrm{Gal} \beta 1,3 \mathrm{GalNAc} \beta 1$ \\
\hline & $4(\mathrm{Neu} 5 \mathrm{Ac} \alpha 2,3) \mathrm{Gal} \beta 1$ \\
\hline & $4 \mathrm{Glc} \beta 1 \mathrm{Cer}$ \\
\hline & $\left(\mathrm{IV}^{3} \mathrm{Neu} 5 \mathrm{AcII}^{3} \mathrm{Neu} 5 \mathrm{AcGg}_{5} \mathrm{Cer}\right)$ \\
\hline Neu5Ac: & N-Acetyl-neuraminic acid \\
\hline Glc: & Glucose \\
\hline Gal: & Galactose \\
\hline GalNAc: & N-Acetyl-galactosamine. \\
\hline
\end{tabular}

\section{Conflict of Interests}

The author has no direct financial relation with any commercial identity mentioned in the paper that might lead to a conflict of interests.

\section{Acknowledgments}

Support from Professor Dr. K. Sandhoff, the DFG, and the European Community (7th framework program "LipidomicNet", proposal no. 202272) is gratefully acknowledged.

\section{References}

[1] E. Fahy, S. Subramaniam, H. A. Brown et al., "A comprehensive classification system for lipids," Journal of Lipid Research, vol. 46, no. 5, pp. 839-861, 2005.

[2] S. Wickramasinghe and J. F. Medrano, "Primer on genes encoding enzymes in sialic acid metabolism in mammals," Biochimie, vol. 93, pp. 1641-1646, 2011.

[3] T. Miyagi and K. Yamaguchi, "Sialic acids," in Comprehensive Glycoscience, J. P. Kamerling, G. J. Boons, Y. C. Lee, A. Suzuki, N. Taniguchi, and A. G. J. Voragen, Eds., vol. 3, pp. 297-322, Elsevier, Oxford, UK, 2007.

[4] E. Klenk, "Über die Ganglioside, eine neue Gruppe von zuckerhaltigen Gehirnlipoiden," Hoppe-Seyler's Zeitschrift für Physiologische Chemie, vol. 273, pp. 76-86, 1942.

[5] E. Klenk, "Über die Natur der Phosphatide und anderer Lipide des Gehirns und der Leber bei der NiemannPick'schen Krankheit," Zeitschrift für Physiologische Chemie, vol. 235, pp. 24-25, 1935.

[6] E. Klenk, "Über die Ganglioside des Gehirns bei der infantilen amaurotischen Idiotie vom Typ Tay-Sachs," Berichte der Deutschen Chemischen Gesellschaft, vol. 75, pp. 1632-1636, 1942.

[7] E. Klenk, "Die Fettstoffe des Gehirns bei amaurotischer Idiotie und Niemann-Pick'scher Krankheit," Berichte über die Gesamte Physiologie und Experimentelle, vol. 96, pp. 659-660, 1937.

[8] G. Blix, "Über die Kohlenhydratgruppen des Submaxillarismucins," Hoppe-Seyler's Zeitschrift für Physiologische Chemie, vol. 240, pp. 43-54, 1936.

[9] R. Kuhn and H. Wiegandt, "Die Konstitution der Ganglio-Ntetraose und des Gangliosides GI," Chemische Berichte, vol. 96, pp. 866-880, 1963.

[10] L. Svennerholm, "Chromatographic separation of human brain gangliosides," Journal of Neurochemistry, vol. 10, pp. 613-623, 1963.

[11] L. Svennerholm, “The gangliosides,” Journal of Lipid Research, vol. 5, pp. 145-155, 1964.

[12] H. Jatzkewitz and K. Sandhoff, "On a biochemically special form of infantile amaurotic idiocy," Biochimica et Biophysica Acta, vol. 70, no. C, pp. 354-356, 1963.

[13] K. Sandhoff, "Variation of $\beta$-N-acetylhexosaminidase-pattern in Tay-Sachs disease," FEBS Letters, vol. 4, no. 4, pp. 351354, 1969.

[14] K. Sandhoff, U. Andreae, and H. Jatzkewitz, "Deficient hexosaminidase activity in an exceptional case of Tay-Sachs disease with additional storage of kidney globoside in visceral organs," Pathologia Europaea, vol. 3, no. 2, pp. 278-285, 1968.

[15] M. Cohen and A. Varki, "The sialome-far more than the sum of its parts," OMICS, vol. 14, no. 4, pp. 455-464, 2010.

[16] R. K. Yu, M. Yanagisawa, and T. Ariga, "Glycosphingolipid structures," in Comprehensive Glycoscience, J. P. Kamerling, G. J. Boons, Y. C. Lee, A. Suzuki, N. Taniguchi, and A. G. J. Voragen, Eds., vol. 1, pp. 73-122, Elsevier, Oxford, UK, 2007.

[17] R. K. Yu, Y. T. Tsai, T. Ariga, and M. Yanagisawa, "Structures, biosynthesis, and functions of gangliosides-an overview," Journal of Oleo Science, vol. 60, pp. 537-544, 2011.

[18] R. Schauer, "Sialic acids: fascinating sugars in higher animals and man," Zoology, vol. 107, no. 1, pp. 49-64, 2004.

[19] T. Angata and A. Varki, "Chemical diversity in the sialic acids and related $\alpha$-keto acids: an evolutionary perspective," Chemical Reviews, vol. 102, no. 2, pp. 439-469, 2002. 
[20] R. Schauer, "Sialic acids as regulators of molecular and cellular interactions," Current Opinion in Structural Biology, vol. 19, no. 5, pp. 507-514, 2009.

[21] G. Kohla and R. Schauer, "Sialic acids in gangliosides: origin and function," in Neuroglycobiology, Oxford University Press, Oxford, UK, 2005.

[22] M. A. Chester, "Nomenclature of glycolipids," Pure and Applied Chemistry, vol. 69, pp. 2475-2487, 1997.

[23] S. Ando, "Neuronal dysfunction with aging and its amelioration," Proceedings of the Japan Academy B, vol. 88, pp. 266282, 2012.

[24] H. Suila, V. Pitkänen, T. Hirvonen et al., "Are globoseries glycosphingolipids SSEA-3 and -4 markers for stem cells derived from human umbilical cord blood?" Journal of Molecular Cell Biology, vol. 3, no. 2, pp. 99-107, 2011.

[25] Y. T. Li, "On the structural elucidation of GalNAc-GD1a," Neurochemical Research, vol. 37, pp. 1150-1153, 2012.

[26] H. Yoshino, T. Ariga, A. Suzuki, R. K. Yu, and T. Miyatake, "Identification of gangliosides recognized by IgG anti-GalNAc-GD1a antibodies in bovine spinal motor neurons and motor nerves," Brain Research, vol. 1227, no. C, pp. 216-220, 2008.

[27] K. Kaida, M. Sonoo, G. Ogawa et al., "GM1/GalNAc-GD1a complex: a target for pure motor Guillain-Barré syndrome," Neurology, vol. 71, no. 21, pp. 1683-1690, 2008.

[28] C. W. Ang, N. Yuki, B. C. Jacobs et al., "Rapidly progressive, predominantly motor Guillain-Barre syndrome with antiGalNAc-GD1a antibodies," Neurology, vol. 53, no. 9, pp. 2122-2127, 1999.

[29] N. Yuki and H. P. Hartung, "Medical progress guillain-barre syndrome," The New England Journal of Medicine, vol. 366, pp. 2294-2304, 2012.

[30] T. Yamazaki, M. Suzuki, T. Irie, T. Watanabe, H. Mikami, and S. Ono, "Amyotrophic lateral sclerosis associated with IgG anti-GalNAc-GD1a antibodies," Clinical Neurology and Neurosurgery, vol. 110, no. 7, pp. 722-724, 2008.

[31] Y. T. Li, K. Maskos, C. W. Chou, R. B. Cole, and S. C. Li, "Presence of an unusual GM2 derivative, taurine-conjugated GM2, in Tay-Sachs brain," The Journal of Biological Chemistry, vol. 278, no. 37, pp. 35286-35291, 2003.

[32] S. Hakomori, "Structure and functional interaction of glycosphingolipids inducing signal transduction to affect cellular phenotype," in Comprehensive Glycoscience, J. P. Kamerling, G. J. Boons, Y. C. Lee, A. Suzuki, N. Taniguchi, and A. G. J. Voragen, Eds., vol. 4, pp. 267-288, Elsevier, Oxford, UK, 2007.

[33] T. Nakao, K. Kon, S. Ando et al., "Novel lacto-ganglio type gangliosides with $\mathrm{G}(\mathrm{M} 2)$-epitope in bovine brain which react with IgM from a patient of the amyotrophic lateral sclerosislike disorder," The Journal of Biological Chemistry, vol. 268, no. 28, pp. 21028-21034, 1993.

[34] R. Kannagi, N. A. Cochran, F. Ishigami et al., "Stagespecific embryonic antigens (SSEA-3 and -4) are epitopes of a unique globo-series ganglioside isolated from human teratocarcinoma cells," The EMBO Journal, vol. 2, no. 12, pp. 2355-2361, 1983.

[35] S. B. Levery, M. E. K. Salyan, S. J. Steele et al., "A revised structure for the disialosyl globo-series gangliosides of human erythrocytes and chicken skeletal muscle," Archives of Biochemistry and Biophysics, vol. 312, no. 1, pp. 125-134, 1994.

[36] A. E. Stapleton, M. R. Stroud, S. I. Hakomori, and W. E. Stamm, "The globoseries glycosphingolipid sialosyl galactosyl globoside is found in urinary tract tissues and is a preferred binding receptor in vitro for uropathogenic
Escherichia coli expressing pap-encoded adhesins," Infection and Immunity, vol. 66, no. 8, pp. 3856-3861, 1998.

[37] M. Yanagisawa, "Stem cell glycolipids," Neurochemical Research, vol. 36, pp. 1623-1635, 2011.

[38] M. Sugita, "Studies on the glycosphingolipids of the starfish, Asterina pectinifera: III. Isolation and structural studies of two novel gangliosides containing internal sialic acid residues," Journal of Biochemistry, vol. 86, no. 3, pp. 765-772, 1979.

[39] G. P. Smirnova and N. K. Kochetkov, "A novel sialoglycolipid from hepatopancreas of the starfish Patiria pectinifera," Biochimica et Biophysica Acta, vol. 618, no. 3, pp. 486-495, 1980.

[40] R. Higuchi, M. Inagaki, K. Yamada, and T. Miyamoto, "Biologically active gangliosides from echinoderms," Journal of Natural Medicines, vol. 61, no. 4, pp. 367-370, 2007.

[41] T. Hori and M. Sugita, "Sphingolipids in lower animals," Progress in Lipid Research, vol. 32, no. 1, pp. 25-45, 1993.

[42] S. Itonori and M. Sugita, "Glycophylogenetic aspects of lower animals," in Comprehensive Glycoscience, J. P. Kamerling, J. P. Kamerling, G. J. Boons et al., Eds., vol. 3, pp. 253-284, Elsevier, Oxford, UK, 2007.

[43] M. Inagaki, M. Shiizaki, T. Hiwatashi, T. Miyamoto, and R. Higuchi, "Constituents of crinoidea. 5. Isolation and structure of a new glycosyl inositolphosphoceramide-type ganglioside from the feather star Comanthina schlegeli," Chemical and Pharmaceutical Bulletin, vol. 55, no. 11, pp. 1649-1651, 2007.

[44] K. Arao, M. Inagaki, T. Miyamoto, and R. Higuchi, "Constituents of crinoidea. 3. Isolation and structure of a glycosyl inositolphosphoceramide-type ganglioside with neuritogenic activity from the feather star Comanthus japonica," Chemical and Pharmaceutical Bulletin, vol. 52, no. 9, pp. 1140-1142, 2004.

[45] M. Kaneko, K. Yamada, T. Miyamoto, M. Inagaki, and R. Higuchi, "Neuritogenic activity of gangliosides from echinoderms and their structure-activity relationship," Chemical and Pharmaceutical Bulletin, vol. 55, no. 3, pp. 462-463, 2007.

[46] M. Kaneko, F. Kisa, K. Yamada, T. Miyamoto, and R. Higuchi, "Structure of a new neuritogenic-active ganglioside from the sea cucumber Stichopus japonicus," European Journal of Organic Chemistry, no. 6, pp. 1004-1008, 2003.

[47] R. Higuchi, S. Matsumoto, R. Isobe, and T. Miyamoto, "Structure determination of the major component of the starfish ganglioside molecular species LG-2 by tandem mass spectrometry," Tetrahedron, vol. 51, no. 33, pp. 8961-8968, 1995.

[48] M. Inagaki, T. Miyamoto, R. Isobe, and R. Higuchi, "Biologically active glycosides from asteroidea, 43. Isolation and structure of a new neuritogenic-active ganglioside molecular species from the starfish Linckia laevigata," Chemical and Pharmaceutical Bulletin, vol. 53, no. 12, pp. 1551-1554, 2005.

[49] J. R. Rich and S. G. Withers, "A chemoenzymatic total synthesis of the neurogenic starfish ganglioside LLG-3 using an engineered and evolved synthase," Angewandte Chemie, vol. 51, pp. 8640-8643, 2012.

[50] H. Tamai, H. Ando, H. N. Tanaka et al., "The total synthesis of the neurogenic ganglioside LLG-3 isolated from the starfish Linckia laevigata," Angewandte Chemie, vol. 50, no. 10, pp. 2330-2333, 2011.

[51] S. T. Pruett, A. Bushnev, K. Hagedorn et al., "Biodiversity of sphingoid bases ("sphingosines") and related amino alcohols," Journal of Lipid Research, vol. 49, no. 8, pp. 1621-1639, 2008. 
[52] S. Dasgupta, S. B. Levery, and E. L. Hogan, "3-O-acetylsphingosine-series myelin glycolipids: characterization of novel 3-O-acetyl-sphingosine galactosylceramide," Journal of Lipid Research, vol. 43, no. 5, pp. 751-761, 2002.

[53] H. Hama, "Fatty acid 2-Hydroxylation in mammalian sphingolipid biology," Biochimica et Biophysica Acta, vol. 1801, no. 4, pp. 405-414, 2010.

[54] R. Mahfoud, A. Manis, B. Binnington, C. Ackerley, and C. A. Lingwood, "A major fraction of glycosphingolipids in model and cellular cholesterol-containing membranes is undetectable by their binding proteins," The Journal of Biological Chemistry, vol. 285, no. 46, pp. 36049-36059, 2010.

[55] C. A. Lingwood, A. Manis, R. Mahfoud, F. Khan, B. Binnington, and M. Mylvaganam, "New aspects of the regulation of glycosphingolipid receptor function," Chemistry and Physics of Lipids, vol. 163, no. 1, pp. 27-35, 2010.

[56] D. J. Chinnapen, W. T. Hsieh, Y. M. Te Welscher et al., "Lipid sorting by ceramide structure from plasma membrane to ER for the cholera toxin receptor ganglioside GM1," Developmental Cell, vol. 23, pp. 573-586, 2012.

[57] I. Kracun, H. Rosner, C. Cosovic, and A. Stavljenic, "Topographical atlas of the gangliosides of the adult human brain," Journal of Neurochemistry, vol. 43, no. 4, pp. 979-989, 1984.

[58] H. Rahmann, "Brain gangliosides and memory formation," Behavioural Brain Research, vol. 66, no. 1-2, pp. 105-116, 1995.

[59] B. Wang, "Sialic acid is an essential nutrient for brain development and cognition," Annual Review of Nutrition, vol. 29, pp. 177-222, 2009.

[60] K. Hirschberg, R. Zisling, G. Van Echten-Deckert, and A. H. Futerman, "Ganglioside synthesis during the development of neuronal polarity: major changes occur during axonogenesis and axon elongation, but not during dendrite growth or synaptogenesis," The Journal of Biological Chemistry, vol. 271, no. 25, pp. 14876-14882, 1996.

[61] M. Iwamori, J. Shimomura, S. Tsuyuhara, and Y. Nagai, "Gangliosides of various rat tissues: distribution of ganglio$\mathrm{N}$-tetraose-containing gangliosides and tissue-characteristic composition of gangliosides," Journal of Biochemistry, vol. 95, no. 3, pp. 761-770, 1984.

[62] T. Yamashita, R. Wada, T. Sasaki et al., "A vital role for glycosphingolipid synthesis during development and differentiation," Proceedings of the National Academy of Sciences of the United States of America, vol. 96, no. 16, pp. 9142-9147, 1999.

[63] D. H. Kwak, B. B. Seo, K. T. Chang, and Y. K. Choo, "Roles of gangliosides in mouse embryogenesis and embryonic stem cell differentiation," Experimental and Molecular Medicine, vol. 43, no. 7, pp. 379-388, 2011.

[64] S. I. Hakomori, "Tumor malignancy defined by aberrant glycosylation and sphingo(glyco)lipid metabolism," Cancer Research, vol. 56, no. 23, pp. 5309-5318, 1996.

[65] E. Posse de Chaves and S. Sipione, "Sphingolipids and gangliosides of the nervous system in membrane function and dysfunction," FEBS Letters, vol. 584, no. 9, pp. 1748-1759, 2010.

[66] R. K. Yu, Y. Nakatani, and M. Yanagisawa, "The role of glycosphingolipid metabolism in the developing brain," Journal of Lipid Research, vol. 50, pp. S440-445, 2009.

[67] K. Segler Stahl, J. C. Webster, and E. G. Brunngraber, "Changes in the concentration and composition of human brain gangliosides with aging," Gerontology, vol. 29, no. 3, pp. 161$168,1983$.
[68] E. Ozkok, S. Cengiz, and B. Guvener, "Age-dependent changes in liver ganglioside levels," Journal of Basic \& Clinical Physiology \& Pharmacology, vol. 10, pp. 337-344, 1999.

[69] H. J. Senn, M. Orth, E. Fitzke, H. Wieland, and W. Gerok, "Ganglioside in normal human serum. Concentration, pattern and transport by lipoproteins," European Journal of Biochemistry, vol. 181, no. 3, pp. 657-662, 1989.

[70] G. Muller, "Microvesicles/exosomes as potential novel biomarkers of metabolic diseases," Diabetes, Metabolic Syndrome and Obesity, vol. 5, pp. 247-282, 2012.

[71] C. Dumontet, A. Rebbaa, and J. Portoukalian, "Kinetics and organ distribution of [14C]-sialic acid-GM3 and [3H]sphingosine-GM1 after intravenous injection in rats," Biochemical and Biophysical Research Communications, vol. 189, no. 3, pp. 1410-1416, 1992.

[72] H. Miller-Podraza, R. M. Bradley, and P. H. Fishman, "Biosynthesis and localization of gangliosides in cultured cells," Biochemistry, vol. 21, no. 14, pp. 3260-3265, 1982.

[73] T. Garofalo, A. Tinari, P. Matarrese et al., "Do mitochondria act as "cargo boats" in the journey of GD3 to the nucleus during apoptosis?" FEBS Letters, vol. 581, no. 21, pp. 38993903, 2007.

[74] R. Ledeen and G. Wu, "New findings on nuclear gangliosides: overview on metabolism and function," Journal of Neurochemistry, vol. 116, no. 5, pp. 714-720, 2011.

[75] N. C. Lucki and M. B. Sewer, "Nuclear sphingolipid metabolism," Annual Review of Physiology, vol. 74, pp. 131-151, 2012.

[76] G. Kohla, E. Stockfleth, and R. Schauer, "Gangliosides with $\mathrm{O}$-acetylated sialic acids in tumors of neuroectodermal origin," Neurochemical Research, vol. 27, no. 7-8, pp. 583592, 2002.

[77] C. Schwegmann-Wessels and G. Herrler, "Sialic acids as receptor determinants for coronaviruses," Glycoconjugate Journal, vol. 23, no. 1-2, pp. 51-58, 2006.

[78] Y. N. Malykh, R. Schauer, and L. Shaw, "N-Glycolylneuraminic acid in human tumours," Biochimie, vol. 83, no. 7, pp. 623-634, 2001.

[79] D. Ghaderi, M. Zhang, N. Hurtado-Ziola, and A. Varki, "Production platforms for biotherapeutic glycoproteins. Occurrence, impact, and challenges of non-human sialylation," Biotechnology \& Genetic Engineering Reviews, vol. 28, pp. 147-175, 2012.

[80] R. Schauer, G. V. Srinivasan, B. Coddeville, J. P. Zanetta, and Y. Guérardel, "Low incidence of N-glycolylneuraminic acid in birds and reptiles and its absence in the platypus," Carbohydrate Research, vol. 344, no. 12, pp. 1494-1500, 2009.

[81] K. H. Song, Y. J. Kang, U. H. Jin et al., "Cloning and functional characterization of pig CMP- $\mathrm{N}$-acetylneuraminic acid hydroxylase for the synthesis of $\mathrm{N}$-glycolylneuraminic acid as the xenoantigenic determinant in pig-human xenotransplantation," Biochemical Journal, vol. 427, no. 1, pp. 179-188, 2010.

[82] G. A. Andrews, P. S. Chavey, J. E. Smith, and L. Rich, "Nglycolylneuraminic acid and $\mathrm{N}$-acetylneuraminic acid define feline blood group A and B antigens," Blood, vol. 79, no. 9, pp. 2485-2491, 1992.

[83] H. H. Chou, H. Takematsu, S. Diaz et al., "A mutation in human CMP-sialic acid hydroxylase occurred after the Homo-Pan divergence," Proceedings of the National Academy of Sciences of the United States of America, vol. 95, no. 20, pp. 11751-11756, 1998. 
[84] A. Varki, "Multiple changes in sialic acid biology during human evolution," Glycoconjugate Journal, vol. 26, no. 3, pp. 231-245, 2009.

[85] A. Varki, "Uniquely human evolution of sialic acid genetics and biology," Proceedings of the National Academy of Sciences of the United States of America, vol. 107, supplement 2, pp. 8939-8946, 2010.

[86] S. L. Diaz, V. Padler-Karavani, D. Ghaderi et al., "Sensitive and specific detection of the non-human sialic acid $\mathrm{N}$ Glycolylneuraminic acid in human tissues and biotherapeutic products," PLoS ONE, vol. 4, no. 1, Article ID e4241, 2009.

[87] M. Zarei, J. Müthing, J. Peter-Katalinić, and L. Bindila, "Separation and identification of GM1b pathway Neu5Acand Neu5Gc gangliosides by on-line nanoHPLC-QToF MS and tandem MS: toward glycolipidomics screening of animal cell lines," Glycobiology, vol. 20, no. 1, pp. 118-126, 2010.

[88] R. Blanco, C. E. Rengifo, M. Cedeño, M. Frómeta, E. Rengifo, and A. Carr, "Immunoreactivity of the 14F7 mab (raised against N-Glycolyl GM3 ganglioside) as a positive prognostic factor in non-small-cell lung cancer," Pathology Research International, vol. 2012, Article ID 235418, 12 pages, 2012.

[89] S. K. Gross, M. A. Williams, and R. H. McCluer, "Alkalilabile, sodium borohydride-reducible ganglioside sialic acid residues in brain," Journal of Neurochemistry, vol. 34, no. 6, pp. 1351-1361, 1980.

[90] L. Riboni, S. Sonnino, and D. Acquotti, "Natural occurrence of ganglioside lactones. Isolation and characterization of G(D1b) inner ester from adult human brain," The Journal of Biological Chemistry, vol. 261, no. 18, pp. 8514-8519, 1986.

[91] G. A. Nores, T. Dohi, M. Taniguchi, and S. I. Hakomori, "Density-dependent recognition of cell surface GM3 by a certain anti-melanoma antibody, and GM3 lactone as a possible immunogen: requirements for tumor-associated antigen and immunogen," Journal of Immunology, vol. 139, no. 9, pp. 3171-3176, 1987.

[92] M. Tsuda, T. Terabayashi, and Y. Kawanishi, "Observation of ganglioside lactone formation with CD spectrometry," Chemistry and Physics of Lipids, vol. 70, no. 1, pp. 95-99, 1994.

[93] S. Sonnino and V. Chigorno, "Ganglioside molecular species containing C18- and C20-sphingosine in mammalian nervous tissues and neuronal cell cultures," Biochimica et Biophysica Acta, vol. 1469, no. 2, pp. 63-77, 2000.

[94] P. Palestini, M. Masserini, A. Fiorilli, E. Calappi, and G. Tettamanti, "Age-related changes in the ceramide composition of the major gangliosides present in rat brain subcellular fractions enriched in plasma membranes of neuronal and myelin origin," Journal of Neurochemistry, vol. 61, no. 3, pp. 955-960, 1993.

[95] M. Valsecchi, P. Palestini, V. Chigorno, and S. Sonnino, "Agerelated changes of the ganglioside long-chain base composition in rat cerebellum," Neurochemistry International, vol. 28, no. 2, pp. 183-187, 1996.

[96] P. Palestini, M. Masserini, S. Sonnino, A. Giuliani, and G. Tettamanti, "Changes in the ceramide composition of rat forebrain gangliosides with age," Journal of Neurochemistry, vol. 54, no. 1, pp. 230-235, 1990.

[97] Y. Sugiura, S. Shimma, Y. Konishi, M. K. Yamada, and M. Setou, "Imaging mass spectrometry technology and application on ganglioside study; visualization of age-dependent accumulation of C20-ganglioside molecular species in the mouse hippocampus," PLoS ONE, vol. 3, no. 9, Article ID e3232, 2008.
[98] K. Ogawa-Goto, N. Funamoto, T. Abe, and K. Nagashima, "Different ceramide compositions of gangliosides between human motor and sensory nerves," Journal of Neurochemistry, vol. 55, no. 5, pp. 1486-1493, 1990.

[99] P. McJarrow, N. Schnell, J. Jumpsen, and T. Clandinin, "Influence of dietary gangliosides on neonatal brain development," Nutrition Reviews, vol. 67, no. 8, pp. 451-463, 2009.

[100] R. Rueda, "The role of dietary gangliosides on immunity and the prevention of infection," British Journal of Nutrition, vol. 98, supplement 1, pp. S68-S73, 2007.

[101] H. Farwanah and T. Kolter, "Lipidomics of glycosphingolipids," Metabolites, vol. 2, pp. 134-164, 2012.

[102] R. Lacomba, J. Salcedo, A. Alegría, M. Jesús Lagarda, R. Barberá, and E. Matencio, "Determination of sialic acid and gangliosides in biological samples and dairy products: a review," Journal of Pharmaceutical and Biomedical Analysis, vol. 51, no. 2, pp. 346-357, 2010.

[103] W. Q. Wang and A. Gustafson, "Ganglioside extraction from erythrocytes: a comparison study," Acta Chemica Scandinavica, vol. 49, no. 12, pp. 929-936, 1995.

[104] L. Svennerholm and P. Fredman, "A procedure for the quantitative isolation of brain gangliosides," Biochimica et Biophysica Acta, vol. 617, no. 1, pp. 97-109, 1980.

[105] M. C. Byrne, M. Sbaschnig-Agler, and D. A. Aquino, "Procedure for isolation of gangliosides in high yield and purity: simultaneous isolation of neutral glycosphingolipids," Analytical Biochemistry, vol. 148, no. 1, pp. 163-173, 1985.

[106] J. Folch, M. Lees, and G. H. Sloane Stanley, "A simple method for the isolation and purification of total lipides from animal tissues," The Journal of Biological Chemistry, vol. 226, no. 1, pp. 497-509, 1957.

[107] A. E. Manzi and B. K. Hayes, "Unit 17.21A HPLC methods for the fractionation and analysis of negatively charged oligosaccharides and gangliosides," in Current Protocols in Molecular Biology, chapter 17, 2001.

[108] R. K. Yu and R. W. Ledeen, "Gangliosides of human, bovine, and rabbit plasma," Journal of Lipid Research, vol. 13, no. 5, pp. 680-686, 1972.

[109] X. Jiang, H. Cheng, K. Yang, R. W. Gross, and X. Han, "Alkaline methanolysis of lipid extracts extends shotgun lipidomics analyses to the low-abundance regime of cellular sphingolipids," Analytical Biochemistry, vol. 371, no. 2, pp. 135-145, 2007.

[110] Z. Vukelic, S. Kalanj-Bognar, M. Froesch et al., "Human gliosarcoma-associated ganglioside composition is complex and distinctive as evidenced by high-performance mass spectrometric determination and structural characterization," Glycobiology, vol. 17, no. 5, pp. 504-515, 2007.

[111] F. Scandroglio, N. Loberto, M. Valsecchi, V. Chigorno, A. Prinetti, and S. Sonnino, "Thin layer chromatography of gangliosides," Glycoconjugate Journal, vol. 26, no. 8, pp. 961973, 2009.

[112] E. Sisu, C. Flangea, A. Serb, A. Rizzi, and A. D. Zamfir, "High-performance separation techniques hyphenated to mass spectrometry for ganglioside analysis," Electrophoresis, vol. 32, no. 13, pp. 1591-1609, 2011.

[113] T. Tai, I. Kawashima, and K. Ogura, "Anticarbohydrate antibodies," in Comprehensive Glycoscience, J. P. Kamerling, J. P. Kamerling, G. J. Boons et al., Eds., vol. 3, pp. 765-783, Elsevier, Oxford, UK, 2007.

[114] I. Meisen, M. Mormann, and J. Muthing, "Thin-layer chromatography, overlay technique and mass spectrometry: a versatile triad advancing glycosphingolipidomics," Biochimica et Biophysica Acta, vol. 1811, no. 11, pp. 875-896, 2011. 
[115] T. Valdes-Gonzalez, N. Goto-Inoue, W. Hirano et al., "New approach for glyco- and lipidomics-Molecular scanning of human brain gangliosides by TLC-Blot and MALDI-QITTOF MS," Journal of Neurochemistry, vol. 116, no. 5, pp. 678683, 2011.

[116] H. Kadowaki, J. E. Evans, and R. H. McCluer, "Separation of brain monosialoganglioside molecular species by high-performance liquid chromatography," Journal of Lipid Research, vol. 25, no. 10, pp. 1132-1139, 1984.

[117] G. Gazzotti, S. Sonnino, and R. Ghidoni, "Separation of ganglioside molecular species, with homogeneous longchain base composition, by reversed-phase thin-layer chromatography," Journal of Chromatography, vol. 315, pp. 395400, 1984.

[118] L. Mauri, M. Valsecchi, R. Casellato, S. C. Li, Y. T. Li, and S. Sonnino, "Procedure for separation of GM2 ganglioside species with different ceramide structures by a flash reversedphase silica gel liquid chromatography," Journal of Chromatography B, vol. 796, no. 1, pp. 1-10, 2003.

[119] S. B. Levery, "Glycosphingolipid structural analysis and glycosphingolipidomics," Methods in Enzymology, vol. 405, pp. 300-369, 2006.

[120] M. I. Demarco and R. J. Woods, "Atomic-resolution conformational analysis of the GM3 ganglioside in a lipid bilayer and its implications for ganglioside-protein recognition at membrane surfaces," Glycobiology, vol. 19, no. 4, pp. 344355, 2009.

[121] A. Varki, "Evolutionary forces shaping the Golgi glycosylation machinery: why cell surface glycans are universal to living cells," Cold Spring Harbor Perspectives in Biology, vol. 3, no. 6, Article ID a005462, 2011.

[122] G. Tettamanti, "Ganglioside/glycosphingolipid turnover: new concepts," Glycoconjugate Journal, vol. 20, no. 5, pp. 301$317,2003$.

[123] G. Tettamanti, R. Bassi, P. Viani, and L. Riboni, "Salvage pathways in glycosphingolipid metabolism," Biochimie, vol. 85, no. 3-4, pp. 423-437, 2003.

[124] E. C. Mandon, I. Ehses, J. Rother, G. Van Echten, and K. Sandhoff, "Subcellular localization and membrane topology of serine palmitoyltransferase, 3-dehydrosphinganine reductase, and sphinganine $\mathrm{N}$-acyltransferase in mouse liver," The Journal of Biological Chemistry, vol. 267, no. 16, pp. 11144$11148,1992$.

[125] A. H. Merrill, "Sphingolipid and glycosphingolipid metabolic pathways in the era of sphingolipidomics," Chemical Reviews, vol. 111, pp. 6387-6422, 2011.

[126] G. van Meer and S. Hoetzl, "Sphingolipid topology and the dynamic organization and function of membrane proteins," FEBS Letters, vol. 584, no. 9, pp. 1800-1805, 2010.

[127] H. Ikushiro and H. Hayashi, "Mechanistic enzymology of serine palmitoyltransferase," Biochimica et Biophysica Acta, vol. 1814, pp. 1474-1480, 2011.

[128] Y. Hirabayashi and S. Furuya, "Roles of l-serine and sphingolipid synthesis in brain development and neuronal survival," Progress in Lipid Research, vol. 47, no. 3, pp. 188203, 2008.

[129] K. Yoshida, S. Furuya, S. Osuka et al., "Targeted disruption of the mouse 3-phosphoglycerate dehydrogenase gene causes severe neurodevelopmental defects and results in embryonic lethality," The Journal of Biological Chemistry, vol. 279, no. 5, pp. 3573-3577, 2004.

[130] Y. Hirabayashi, "A world of sphingolipids and glycolipids in the brain-novel functions of simple lipids modified with glucose," Proceedings of the Japan Academy B, vol. 88, pp. 129$143,2012$.

[131] T. D. Mullen, Y. A. Hannun, and L. M. Obeid, "Ceramide synthases at the centre of sphingolipid metabolism and biology," Biochemical Journal, vol. 441, pp. 789-802, 2012.

[132] L. Zhao, S. D. Spassieva, T. J. Jucius et al., "A deficiency of ceramide biosynthesis causes cerebellar purkinje cell neurodegeneration and lipofuscin accumulation," PLoS Genetics, vol. 7, no. 5, Article ID e1002063, 2011.

[133] Y. Mizutani, A. Kihara, H. Chiba, H. Tojo, and Y. Igarashi, "2-Hydroxy-ceramide synthesis by ceramide synthase family: enzymatic basis for the preference of FA chain length," Journal of Lipid Research, vol. 49, no. 11, pp. 2356-2364, 2008.

[134] G. Fabrias, J. Munoz-Olaya, F. Cingolani et al., "Dihydroceramide desaturase and dihydrosphingolipids: debutant players in the sphingolipid arena," Progress in Lipid Research, vol. 51, pp. 82-94, 2012.

[135] K. Hanada, "Intracellular trafficking of ceramide by ceramide transfer protein," Proceedings of the Japan Academy B, vol. 86, no. 4, pp. 426-437, 2010.

[136] M. A. Olayioye and A. Hausser, "Integration of non-vesicular and vesicular transport processes at the Golgi complex by the PKD-CERT network," Biochimica et Biophysica Acta, vol. 1821, pp. 1096-1103, 2012.

[137] K. Hanada, K. Kumagai, N. Tomishige, and T. Yamaji, "CERT-mediated trafficking of ceramide," Biochimica et Biophysica Acta, vol. 1791, no. 7, pp. 684-691, 2009.

[138] J. L. Daniotti and R. Iglesias-Bartolomé, "Metabolic pathways and intracellular trafficking of gangliosides," IUBMB Life, vol. 63, no. 7, pp. 513-520, 2011.

[139] W. W. Young, M. S. Lutz, and W. A. Blackburn, "Endogenous glycosphingolipids move to the cell surface at a rate consistent with bulk flow estimates," The Journal of Biological Chemistry, vol. 267, no. 17, pp. 12011-12015, 1992.

[140] H. J. F. MacCioni, R. Quiroga, and M. L. Ferrari, "Cellular and molecular biology of glycosphingolipid glycosylation," Journal of Neurochemistry, vol. 117, no. 4, pp. 589-602, 2011.

[141] T. Kolter, R. L. Proia, and K. Sandhoff, "Combinatorial ganglioside biosynthesis," The Journal of Biological Chemistry, vol. 277, no. 29, pp. 25859-25862, 2002.

[142] S. C. Basu, "The serendipity of ganglioside biosynthesis: pathway to CARS and HY-CARS glycosyltransferases," Glycobiology, vol. 1, no. 5, pp. 469-475, 1991.

[143] G. Pohlentz, D. Klein, G. Schwarzmann, D. Schmitz, and K. Sandhoff, "Both GA2, GM2, and GD2 synthases and GM1b, GD1a, and GT1b synthases are single enzymes in Golgi vesicles from rat liver," Proceedings of the National Academy of Sciences of the United States of America, vol. 85, no. 19, pp. 7044-7048, 1988.

[144] H. Iber, R. Kaufmann, G. Pohlentz, G. Schwarzmann, and K. Sandhoff, "Identity of G(A1), G(M1a) and G(D1b) synthase in Golgi vesicles from rat liver," FEBS Letters, vol. 248, no. 1-2, pp. 18-22, 1989.

[145] H. Iber and K. Sandhoff, "Identity of G(D1C), G(T1a) and $\mathrm{G}(\mathrm{Q} 1 \mathrm{~b})$ synthase in Golgi vesicles from rat liver," FEBS Letters, vol. 254, no. 1-2, pp. 124-128, 1989.

[146] H. Iber, G. Van Echten, and K. Sandhoff, "Substrate specificity of $\alpha 2 \rightarrow 3$-sialyltransferases in ganglioside biosynthesis of rat liver Golgi," European Journal of Biochemistry, vol. 195, no. 1, pp. 115-120, 1991.

[147] H. Iber, C. Zacharias, and K. Sandhoff, "The c-series gangliosides $\mathrm{G}(\mathrm{T} 3), \mathrm{G}(\mathrm{T} 2)$ and $\mathrm{G}(\mathrm{P} 1 \mathrm{c})$ are formed in rat liver Golgi by the same set of glycosyltransferases that catalyse 
the biosynthesis of asialo-, a- and b-series gangliosides," Glycobiology, vol. 2, no. 2, pp. 137-142, 1992.

[148] M. Audry, C. Jeanneau, A. Imberty, A. Harduin-Lepers, P. Delannoy, and C. Breton, "Current trends in the structureactivity relationships of sialyltransferases," Glycobiology, vol. 21, no. 6, pp. 716-726, 2011.

[149] A. Harduin-Lepers, "Comprehensive analysis of sialyltransferases in vertebrate genomes," Glycobiology Insights, vol. 2, pp. 29-61, 2010.

[150] L. Svennerholm, B. M. Rynmark, G. Vilbergsson et al., "Gangliosides in human fetal brain," Journal of Neurochemistry, vol. 56 , no. 5, pp. 1763-1768, 1991.

[151] M. Kotani, I. Kawashima, H. Ozawa, T. Terashima, and T. Tai, "Differential distribution of major gangliosides in rat central nervous system detected by specific monoclonal antibodies," Glycobiology, vol. 3, no. 2, pp. 137-146, 1993.

[152] T. R. Henion, D. Zhou, D. P. Wolfer, F. B. Jungalwala, and T. Hennet, "Cloning of a Mouse $\beta 1,3 \mathrm{~N}$-Acetylglucosaminyltrans-fer-ase $\operatorname{GlcNAc}(\beta 1,3) \mathrm{Gal}(\beta 1,4)$ Glc-ceramide Synthase Gene Encoding the Key Regulator of Lacto-series Glycolipid Biosynthesis," The Journal of Biological Chemistry, vol. 276, no. 32, pp. 30261-30269, 2001.

[153] A. Togayachi, T. Akashima, R. Ookubo et al., "Molecular Cloning and Characterization of UDP-GlcNAc:Lactosylceramide $\beta 1,3-\mathrm{N}$-Acetylglucosaminyltransferase ( $\beta 3 \mathrm{Gn}$-T5), an Essential Enzyme for the Expression of HNK-1 and Lewis X Epitopes on Glycolipids," The Journal of Biological Chemistry, vol. 276, no. 25, pp. 22032-22040, 2001.

[154] C. T. Kuan, J. Chang, J. E. Mansson et al., "Multiple phenotypic changes in mice after knockout of the B3gnt5 gene, encoding Lc3 synthase-a key enzyme in lacto-neolacto ganglioside synthesis," BMC Developmental Biology, vol. 10, p. 114, 2010.

[155] D. K. H. Chou and F. B. Jungalwala, "N-acetylglucosaminyl transferase regulates the expression of the sulfoglucuronyl glycolipids in specific cell types in cerebellum during development," The Journal of Biological Chemistry, vol. 271, no. 46, pp. 28868-28874, 1996.

[156] M. A. Simpson, H. Cross, C. Proukakis et al., "Infantile-onset symptomatic epilepsy syndrome caused by a homozygous loss-of-function mutation of GM3 synthase," Nature Genetics, vol. 36, no. 11, pp. 1225-1229, 2004.

[157] G. Scheel, E. Acevedo, and E. Conzelmann, "Model for the interaction of membrane-bound substrates and enzymes. Hydrolysis of ganglioside G(D1a) by sialidase of neuronal membranes isolated from calf brain," European Journal of Biochemistry, vol. 127, no. 2, pp. 245-253, 1982.

[158] G. Zhu, M. L. Allende, E. Jaskiewicz et al., "Two soluble glycosyltransferases glycosylate less efficiently in vivo than their membrane bound counterparts," Glycobiology, vol. 8, no. 8, pp. 831-840, 1998.

[159] P. M. Crespo, V. T. Demichelis, and J. L. Daniotti, "Neobiosynthesis of glycosphingolipids by plasma membraneassociated glycosyltransferases," The Journal of Biological Chemistry, vol. 285, no. 38, pp. 29179-29190, 2010.

[160] A. Banchet-Cadeddu, E. Hénon, M. Dauchez, J. H. Renault, F. Monneaux, and A. Haudrechy, "The stimulating adventure of KRN 7000," Organic and Biomolecular Chemistry, vol. 9, no. 9, pp. 3080-3104, 2011.

[161] R. Kuhn and H. Wiegandt, "Further gangliosides from the human brain," Zeitschrift für Naturforschung B, vol. 19, pp. 256-257, 1964.

[162] R. W. Ledeen, R. K. Yu, and L. F. Eng, "Gangliosides of human myelin: sialosylgalactosylceramide (G7) as a major component," Journal of Neurochemistry, vol. 21, no. 4, pp. 829-839, 1973.

[163] N. Jackman, A. Ishii, and R. Bansal, "Oligodendrocyte development and myelin biogenesis: parsing out the roles of glycosphingolipids," Physiology, vol. 24, no. 5, pp. 290-297, 2009.

[164] J. M. Boggs, W. Gao, J. Zhao, H. J. Park, Y. Liu, and A. Basu, "Participation of galactosylceramide and sulfatide in glycosynapses between oligodendrocyte or myelin membranes," FEBS Letters, vol. 584, no. 9, pp. 1771-1778, 2010.

[165] E. N. Maldonado, N. L. Alderson, P. V. Monje, P. M. Wood, and H. Hama, "FA2H is responsible for the formation of 2hydroxy galactolipids in peripheral nervous system myelin," Journal of Lipid Research, vol. 49, no. 1, pp. 153-161, 2008.

[166] R. J. Stewart and J. M. Boggs, "A carbohydrate-carbohydrate interaction between galactosylceramide-containing liposomes and cerebroside sulfate-containing liposomes: dependence on the glycolipid ceramide composition," Biochemistry, vol. 32, no. 40, pp. 10666-10674, 1993.

[167] L. Saadat, J. L. Dupree, J. Kilkus et al., "Absence of oligodendroglial glucosylceramide synthesis does not result in CNS myelin abnormalities or alter the dysmyelinating phenotype of CGT-deficient mice," GLIA, vol. 58, no. 4, pp. 391-398, 2010.

[168] S. Schulte and W. Stoffel, "Ceramide UDPgalactosyltransferase from myelinating rat brain: purification, cloning, and expression," Proceedings of the National Academy of Sciences of the United States of America, vol. 90, no. 21, pp. 10265-10269, 1993.

[169] G. Tennekoon, M. Zaruba, and J. Wolinsky, “Topography of cerebroside sulfotransferase in Golgi-enriched vesicles from rat brain," Journal of Cell Biology, vol. 97, no. 4, pp. 11071112, 1983.

[170] K. N. J. Burger, P. Van Der Bijl, and G. Van Meer, “Topology of sphingolipid galactosyltransferases in ER and Golgi: transbilayer movement of monohexosyl sphingolipids is required for higher glycosphingolipid biosynthesis," Journal of Cell Biology, vol. 133, no. 1, pp. 15-28, 1996.

[171] H. Sprong, B. Kruithof, R. Leijendekker, J. W. Slot, G. Van Meer, and P. Van Der Sluijs, "UDP-galactose: ceramide galactosyltransferase is a class I integral membrane protein of the endoplasmic reticulum," The Journal of Biological Chemistry, vol. 273, no. 40, pp. 25880-25888, 1998.

[172] S. I. Chisada, Y. Yoshimura, K. Sakaguchi et al., "Zebrafish and mouse $\alpha 2,3$-sialyltransferases responsible for synthesizing GM4 ganglioside," The Journal of Biological Chemistry, vol. 284, no. 44, pp. 30534-30546, 2009.

[173] B. R. Mullin, D. H. Patrick, C. M. B. Poore, and M. T. Smith, "Prevention of experimental allergic encephalomyelitis by ganglioside G(M4)," Brain Research, vol. 296, no. 1, pp. 174176, 1984.

[174] P. Paul, Y. Kamisaka, D. L. Marks, and R. E. Pagano, "Purification and characterization of UDP-glucose:ceramide glucosyltransferase from rat liver Golgi membranes," The Journal of Biological Chemistry, vol. 271, no. 4, pp. 2287-2293, 1996.

[175] S. Ichikawa, H. Sakiyama, G. Suzuki, K. I. Hidari, and Y. Hirabayashi, "Expression cloning of a cDNA for human ceramide glucosyltransferase that catalyzes the first glycosylation step of glycosphingolipid synthesis," Proceedings of the National Academy of Sciences of the United States of America, vol. 93, no. 22, p. 12654, 1996.

[176] D. L. Marks, K. Wu, P. Paul, Y. Kamisaka, R. Watanabe, and R. E. Pagano, "Oligomerization and topology of the Golgi 
membrane protein glucosylceramide synthase," The Journal of Biological Chemistry, vol. 274, no. 1, pp. 451-456, 1999.

[177] D. L. Marks, M. Dominguez, K. Wu, and R. E. Pagano, "Identification of active site residues in glucosylceramide synthase: a nucleotide-binding/catalytic motif conserved with processive $\beta$-glycosyltransferases," The Journal of Biological Chemistry, vol. 276, no. 28, pp. 26492-26498, 2001.

[178] H. Coste, M. B. Martel, and R. Got, "Topology of glucosylceramide synthesis in Golgi membranes from porcine submaxillary glands," Biochimica et Biophysica Acta, vol. 858, no. 1, pp. 6-12, 1986.

[179] D. Jeckel, "Lactosylceramide is synthesized in the lumen of the Golgi apparatus," FEBS Letters, vol. 342, no. 1, pp. 91-96, 1994.

[180] A. Van Helvoort, A. J. Smith, H. Sprong et al., "MDR1 Pglycoprotein is a lipid translocase of broad specificity, while MDR3 P-glycoprotein specifically translocates phosphatidylcholine," Cell, vol. 87, no. 3, pp. 507-517, 1996.

[181] G. Van Meer, D. Halter, H. Sprong, P. Somerharju, and M. R. Egmond, "ABC lipid transporters: extruders, flippases, or flopless activators?" FEBS Letters, vol. 580, no. 4, pp. 11711177, 2006.

[182] D. Halter, S. Neumann, S. M. Van Dijk et al., "Pre- and postGolgi translocation of glucosylceramide in glycosphingolipid synthesis," Journal of Cell Biology, vol. 179, no. 1, pp. 101-115, 2007.

[183] M. Chalat, I. Menon, Z. Turan, and A. K. Menon, "Reconstitution of glucosylceramide flip-flop across endoplasmic reticulum: implications for mechanism of glycosphingolipid biosynthesis," The Journal of Biological Chemistry, vol. 287, pp. 15523-15532, 2012.

[184] G. D’Angelo, E. Polishchuk, G. D. Tullio et al., "Glycosphingolipid synthesis requires FAPP2 transfer of glucosylceramide," Nature, vol. 449, no. 7158, pp. 62-67, 2007.

[185] Y. Yildiz, H. Matern, B. Thompson et al., "Mutation of $\beta$ glucosidase 2 causes glycolipid storage disease and impaired male fertility," Journal of Clinical Investigation, vol. 116, no. 11, pp. 2985-2994, 2006.

[186] K. Furukawa, A. Tsuchida, and K. Furukawa, "Biosynthesis of glycolipids," in Comprehensive Glycoscience, J. P. Kamerling, G. J. Boons, Y. C. Lee, A. Suzuki, N. Taniguchi, and A. G. J. Voragen, Eds., vol. 3, pp. 105-114, Elsevier, Oxford, UK, 2007.

[187] M. Takizawa, T. Nomura, E. Wakisaka et al., "cDNA cloning and expression of human lactosylceramide synthase," Biochimica et Biophysica Acta, vol. 1438, no. 2, pp. 301-304, 1999.

[188] Y. Hirabayashi, A. Hyogo, T. Nakao et al., "Isolation and characterization of extremely minor gangliosides, G(M1b) and $\mathrm{G}(\mathrm{D} 1 \alpha)$, in adult bovine brains as developmentally regulated antigens," The Journal of Biological Chemistry, vol. 265, no. 14, pp. 8144-8151, 1990.

[189] T. Yamashita, A. Hashiramoto, M. Haluzik et al., "Enhanced insulin sensitivity in mice lacking ganglioside GM3," Proceedings of the National Academy of Sciences of the United States of America, vol. 100, no. 6, pp. 3445-3449, 2003.

[190] M. Saito and K. Sugiyama, "Tissue-specific expression of cseries gangliosides in the extraneural system," Biochimica et Biophysica Acta, vol. 1474, no. 1, pp. 88-92, 2000.

[191] Y. Hirabayashi, T. Nakao, F. Irie, V. P. Whittaker, K. Kon, and S. Ando, "Structural characterization of a novel cholinergic neuron-specific ganglioside in bovine brain," The Journal of Biological Chemistry, vol. 267, no. 18, pp. 12973-12978, 1992.
[192] F. Irie, K. I. P. Jwa Hidari, T. Tai, Y. T. Li, Y. Seyama, and Y. Hirabayashi, "Biosynthetic pathway for a new series of gangliosides, GT1a $\alpha$ and GQ1b $\alpha$," FEBS Letters, vol. 351, no. 2, pp. 291-294, 1994.

[193] E. R. Sturgill, K. Aoki, P. H. Lopez et al., "Biosynthesis of the major brain gangliosides GD1a and GT1b," Glycobiology, vol. 10, pp. 1289-1301, 2012.

[194] R. L. Proia, "Glycosphingolipid functions: insights from engineered mouse models," Philosophical Transactions of the Royal Society B, vol. 358, no. 1433, pp. 879-883, 2003.

[195] S. Ichikawa, N. Nakajo, H. Sakiyama, and Y. Hirabayashi, "A mouse B16 melanoma mutant deficient in glycolipids," Proceedings of the National Academy of Sciences of the United States of America, vol. 91, no. 7, pp. 2703-2707, 1994.

[196] K. Takamiya, A. Yamamoto, K. Furukawa et al., "Complex gangliosides are essential in spermatogenesis of mice: possible roles in the transport of testosterone," Proceedings of the National Academy of Sciences of the United States of America, vol. 95, no. 21, pp. 12147-12152, 1998.

[197] K. A. Sheikh, J. Sun, Y. Liu et al., "Mice lacking complex gangliosides develop Wallerian degeneration and myelination defects," Proceedings of the National Academy of Sciences of the United States of America, vol. 96, no. 13, pp. 7532-7537, 1999.

[198] S. Chiavegatto, J. Sun, R. J. Nelson, and R. L. Schnaar, "A functional role for complex gangliosides: motor deficits in GM2/GD2 synthase knockout mice," Experimental Neurology, vol. 166, no. 2, pp. 227-234, 2000.

[199] J. Zhao, K. Furukawa, S. Fukumoto et al., "Attenuation of interleukin 2 signal in the spleen cells of complex gangliosidelacking mice," The Journal of Biological Chemistry, vol. 274, no. 20, pp. 13744-13747, 1999.

[200] M. Nagafuku, K. Okuyama, Y. Onimaru et al., "CD4 and CD8 T cells require different membrane gangliosides for activation," Proceedings of the National Academy of Sciences of the United States of America, vol. 109, pp. E336-E342, 2012.

[201] G. Wu, Z. H. Lu, N. Kulkarni, R. Amin, and R. W. Ledeen, "Mice lacking major brain gangliosides develop parkinsonism," Neurochemical Research, vol. 36, pp. 1706-1714, 2011.

[202] J. S. Schneider, A. Kean, and L. DiStefano, "G(M1) ganglioside rescues substantia nigra pars compacta neurons and increases dopamine synthesis in residual nigrostriatal dopaminergic neurons in MPTP-treated mice," Journal of Neuroscience Research, vol. 42, no. 1, pp. 117-123, 1995.

[203] Z. Martinez, M. Zhu, S. Han, and A. L. Fink, "GM1 specifically interacts with $\alpha$-synuclein and inhibits fibrillation," Biochemistry, vol. 46, no. 7, pp. 1868-1877, 2007.

[204] H. Kawai, M. L. Allende, R. Wada et al., "Mice expressing only monosialoganglioside GM3 exhibit lethal audiogenic seizures," The Journal of Biological Chemistry, vol. 276, no. 10, pp. 6885-6888, 2001.

[205] T. Yamashita, Y. P. Wu, R. Sandhoff et al., "Interruption of ganglioside synthesis produces central nervous system degeneration and altered axon-glial interactions," Proceedings of the National Academy of Sciences of the United States of America, vol. 102, no. 8, pp. 2725-2730, 2005.

[206] T. S. Worgall, "Sphingolipid synthetic pathways are major regulators of lipid homeostasis," in Sphingolipids and Metabolic Disease, L. A. Cowart, Ed., vol. 721, pp. 139-148, Springer, New York, NY, USA, 2011.

[207] D. K. Breslow and J. S. Weissman, "Membranes in balance: mechanisms of sphingolipid homeostasis," Molecular Cell, vol. 40, no. 2, pp. 267-279, 2010. 
[208] R. K. Yu, E. Bieberich, T. Xia, and G. Zeng, "Regulation of ganglioside biosynthesis in the nervous system," Journal of Lipid Research, vol. 45, no. 5, pp. 783-793, 2004.

[209] S. Uemura, S. Yoshida, F. Shishido, and J. I. Inokuchi, "The cytoplasmic tail of GM3 synthase defines its subcellular localization, stability, and in vivo activity," Molecular Biology of the Cell, vol. 20, no. 13, pp. 3088-3100, 2009.

[210] E. Bieberich and R. K. Yu, "Multi-enzyme kinetic analysis of glycolipid biosynthesis," Biochimica et Biophysica Acta, vol. 1432, no. 1, pp. 113-124, 1999.

[211] G. van Echten-Deckert and M. Guravi, "Golgi localization of glycosyltransferases involved in ganglioside biosynthesis," Current Drug Targets, vol. 9, no. 4, pp. 282-291, 2008.

[212] E. Bieberich, S. MacKinnon, J. Silva et al., "Regulation of ganglioside biosynthesis by enzyme complex formation of glycosyltransferases," Biochemistry, vol. 41, no. 38, pp. 11479-11487, 2002.

[213] S. Roseman, "The synthesis of complex carbohydrates by multiglycosyltransferase systems and their potential function in intercellular adhesion," Chemistry and Physics of Lipids, vol. 5, no. 1, pp. 270-297, 1970.

[214] W. Spessott, P. M. Crespo, J. L. Daniotti, and H. J. Maccioni, "Glycosyltransferase complexes improve glycolipid synthesis," FEBS Lett, vol. 586, no. 16, pp. 2346-2350, 2012.

[215] C. G. Giraudo, J. L. Daniotti, and H. J. F. Maccioni, "Physical and functional association of glycolipid N-acetylgalactosaminyl and galactosyl transferases in the Golgi apparatus," Proceedings of the National Academy of Sciences of the United States of America, vol. 98, no. 4, pp. 1625-1630, 2001.

[216] C. G. Giraudo and H. J. F. Maccioni, "Ganglioside glycosyltransferases organize in distinct multienzyme complexes in CHO-K1 cells," The Journal of Biological Chemistry, vol. 278, no. 41, pp. 40262-40271, 2003.

[217] E. Monti, M. T. Bassi, N. Papini et al., "Identification and expression of NEU3, a novel human sialidase associated to the plasma membrane," Biochemical Journal, vol. 349, no. 1, pp. 343-351, 2000.

[218] Y. Wang, K. Yamaguchi, T. Wada et al., "A close association of the ganglioside-specific sialidase Neu3 with caveolin in membrane microdomains," The Journal of Biological Chemistry, vol. 277, no. 29, pp. 26252-26259, 2002.

[219] M. Miyata, M. Kambe, O. Tajima et al., "Membrane sialidase NEU3 is highly expressed in human melanoma cells promoting cell growth with minimal changes in the composition of gangliosides," Cancer Science, vol. 102, pp. 2139-2149, 2011.

[220] J. Wang, G. Wu, T. Miyagi, Z. H. Lu, and R. W. Ledeen, "Sialidase occurs in both membranes of the nuclear envelope and hydrolyzes endogenous GD1a," Journal of Neurochemistry, vol. 111, no. 2, pp. 547-554, 2009.

[221] M. Ito, "Degradation of glycolipids," in Comprehensive Glycoscience, J. P. Kamerling, G. J. Boons, Y. C. Lee, A. Suzuki, N. Taniguchi, and A. G. J. Voragen, Eds., vol. 3, pp. 193-208, Elsevier, Oxford, UK, 2007.

[222] T. Kolter and K. Sandhoff, "Lysosomal degradation of membrane lipids," FEBS Letters, vol. 584, no. 9, pp. 17001712, 2010.

[223] W. Furst and K. Sandhoff, "Activator proteins and topology of lysosomal sphingolipid catabolism," Biochimica et Biophysica Acta, vol. 1126, no. 1, pp. 1-16, 1992.

[224] A. C. Johansson, H. Appelqvist, C. Nilsson, K. Kågedal, K. Roberg, and K. Öllinger, "Regulation of apoptosis-associated lysosomal membrane permeabilization," Apoptosis, vol. 15, no. 5, pp. 527-540, 2010.
[225] W. Möbius, E. van Donselaar, Y. Ohno-Iwashita et al., "Recycling compartments and the internal vesicles of multivesicular bodies harbor most of the cholesterol found in the endocytic pathway," Traffic, vol. 4, no. 4, pp. 222-231, 2003.

[226] H. D. Gallala and K. Sandhoff, "Biological function of the cellular lipid BMP-BMP as a key activator for cholesterol sorting and membrane digestion," Neurochemical Research, vol. 36, pp. 1594-1600, 2011.

[227] M. Scherer and G. Schmitz, "Metabolism, function and mass spectrometric analysis of bis(monoacylglycero)phosphate and cardiolipin," Chemistry and Physics of Lipids, vol. 164, no. 6, pp. 556-562, 2011.

[228] T. Kobayashi, M. H. Beuchat, J. Chevallier et al., "Separation and characterization of late endosomal membrane domains," The Journal of Biological Chemistry, vol. 277, no. 35, pp. 32157-32164, 2002.

[229] P. Saftig and J. Klumperman, "Lysosome biogenesis and lysosomal membrane proteins: trafficking meets function," Nature Reviews Molecular Cell Biology, vol. 10, no. 9, pp. 623635, 2009.

[230] P. Saftig, B. Schröder, and J. Blanz, "Lysosomal membrane proteins: life between acid and neutral conditions," Biochemical Society Transactions, vol. 38, no. 6, pp. 1420-1423, 2010.

[231] R. Henning and W. Stoffel, "Glycosphingolipids in lysosomal membranes," Hoppe-Seyler's Zeitschrift für Physiologische Chemie, vol. 354, no. 7, pp. 760-770, 1973.

[232] E. M. Meier, G. Schwarzmann, W. Furst, and K. Sandhoff, "The human G(M2) activator protein. A substrate specific cofactor of $\beta$-hexosaminidase A," The Journal of Biological Chemistry, vol. 266, no. 3, pp. 1879-1887, 1991.

[233] T. Kolter and K. Sandhoff, "Principles of lysosomal membrane digestion: stimulation of sphingolipid degradation by sphingolipid activator proteins and anionic lysosomal lipids," Annual Review of Cell and Developmental Biology, vol. 21, pp. 81-103, 2005.

[234] S. Locatelli-Hoops, N. Remmel, R. Klingenstein et al., "Saposin A mobilizes lipids from low cholesterol and high bis(monoacylglycerol)phosphate-containing membranes: patient variant saposin a lacks lipid extraction capacity," The Journal of Biological Chemistry, vol. 281, no. 43, pp. 32451-32460, 2006.

[235] N. Remmel, S. Locatelli-Hoops, B. Breiden, G. Schwarzmann, and K. Sandhoff, "Saposin B mobilizes lipids from cholesterol-poor and bis(monoacylglycero) phosphate-rich membranes at acidic $\mathrm{pH}$ : unglycosylated patient variant saposin B lacks lipid-extraction capacity," FEBS Journal, vol. 274, no. 13, pp. 3405-3420, 2007.

[236] N. Werth, C. G. Schuette, G. Wilkening, T. Lemm, and K. Sandhoff, "Degradation of membrane-bound ganglioside GM2 by $\beta$-hexosaminidase A. Stimulation by GM2 activator protein and lysosomal lipids," The Journal of Biological Chemistry, vol. 276, no. 16, pp. 12685-12690, 2001.

[237] G. Wilkening, T. Linke, G. Uhlhorn-Dierks, and K. Sandhoff, "Degradation of membrane-bound ganglioside GM1: stimulation by bis(monoacylglycero)phosphate and the activator proteins SAP-B and GM2-AP," The Journal of Biological Chemistry, vol. 275, no. 46, pp. 35814-35819, 2000.

[238] S. T. Hepbildikler, R. Sandhoff, M. Kölzer, R. L. Proia, and K. Sandhoff, "Physiological substrates for human lysosomal $\beta$ hexosaminidase S," The Journal of Biological Chemistry, vol. 277, no. 4, pp. 2562-2572, 2002.

[239] R. Sandhoff, S. T. Hepbildikler, R. Jennemann et al., "Kidney sulfatides in mouse models of inherited glycosphingolipid disorders: determination by nano-electrospray ionization 
tandem mass spectrometry," The Journal of Biological Chemistry, vol. 277, no. 23, pp. 20386-20398, 2002.

[240] M. Abdul-Hammed, B. Breiden, M. A. Adebayo, J. O. Babalola, G. Schwarzmann, and K. Sandhoff, "Role of endosomal membrane lipids and NPC2 in cholesterol transfer and membrane fusion," Journal of Lipid Research, vol. 51, no. 7, pp. 1747-1760, 2010.

[241] H. Bruhn, "A short guided tour through functional and structural features of saposin-like proteins," Biochemical Journal, vol. 389, no. 2, pp. 249-257, 2005.

[242] E. Mehl and H. Jatzkewitz, "A cerebrosidesulfatase from swine kidney," Hoppe-Seyler's Zeitschrift für Physiologische Chemie, vol. 339, no. 1, pp. 260-276, 1964.

[243] A. Vogel, G. Schwarzmann, and K. Sandhoff, "Glycosphingolipid specificity of the human sulfatide activator protein," European Journal of Biochemistry, vol. 200, no. 2, pp. 591597, 1991.

[244] G. Fischer and H. Jatzkewitz, "The activator of cerebroside sulphatase. Binding studies with enzyme and substrate demonstrating the detergent function of the activator protein," Biochimica et Biophysica Acta, vol. 481, no. 2, pp. 561572, 1977.

[245] E. Conzelmann, M. Lee-Vaupel, and K. Sandhoff, "The physiological role of activator proteins for lysosomal glycolipid degradation," in Lipid Storage Disorders: Biological and Medical Aspects, R. Salvayre, L. Douste-Blazy, and S. Gatt, Eds., vol. 150, pp. 323-332, Pergamon Press, New York, NY, USA, 1988.

[246] B. Schmid, B. C. Paton, K. Sandhoff, and K. Harzer, "Metabolism of $\mathrm{G}(\mathrm{M} 1)$ ganglioside in cultured skin fibroblasts: anomalies in gangliosidoses, sialidoses, and sphingolipid activator protein (SAP, saposin) 1 and prosaposin deficient disorders," Human Genetics, vol. 89, no. 5, pp. 513-518, 1992.

[247] V. E. Ahn, K. F. Faull, J. P. Whitelegge, A. L. Fluharty, and G. G. Privé, "Crystal structure of saposin B reveals a dimeric shell for lipid binding," Proceedings of the National Academy of Sciences of the United States of America, vol. 100, no. 1, pp. 38-43, 2003.

[248] K. A. Kretz, G. S. Carson, S. Morimoto, Y. Kishimoto, A. L. Fluharty, and J. S. O'Brien, "Characterization of a mutation in a family with saposin B deficiency: a glycosylation site defect," Proceedings of the National Academy of Sciences of the United States of America, vol. 87, no. 7, pp. 2541-2544, 1990.

[249] Y. Sun, D. P. Witte, H. Ran et al., "Neurological deficits and glycosphingolipid accumulation in saposin B deficient mice," Human Molecular Genetics, vol. 17, no. 15, pp. 2345-2356, 2008.

[250] E. Conzelmann and K. Sandhoff, "Purification and characterization of an activator protein for the degradation of glycolipids G(M2) and G(A2) by hexosaminidase A," HoppeSeyler's Zeitschrift für Physiologische Chemie, vol. 360, no. 12, pp. 1837-1849, 1979.

[251] E. Conzelmann and K. Sandhoff, "AB variant of infantile $\mathrm{Gm} 2$ gangliosidosis. Deficiency of a factor necessary for stimulation of hexosaminidase A-catalyzed degradation of ganglioside Gm2 and glycolipid Ga2," Proceedings of the National Academy of Sciences of the United States of America, vol. 75, no. 8, pp. 3979-3983, 1978.

[252] C. S. Wright, S. C. Li, and F. Rastinejad, "Crystal structure of human GM2-activator protein with a novel $\beta$-cup topology," Journal of Molecular Biology, vol. 304, no. 3, pp. 411-422, 2000.
[253] C. S. Wright, Q. Zhao, and F. Rastinejad, "Structural analysis of lipid complexes of GM2-activator protein," Journal of Molecular Biology, vol. 331, no. 4, pp. 951-964, 2003.

[254] M. Wendeler, J. Hoernschemeyer, D. Hoffmann, T. Kolter, G. Schwarzmann, and K. Sandhoff, "Photoaffinity labelling of the Human GM2-activator protein Mechanistic insight into ganglioside GM2 degradation," European Journal of Biochemistry, vol. 271, no. 3, pp. 614-627, 2004.

[255] J. D. Mathias, Y. Ran, J. D. Carter, and G. E. Fanucci, "Interactions of the GM2 activator protein with phosphatidylcholine bilayers: a site-directed spin-labeling power saturation study," Biophysical Journal, vol. 97, no. 5, pp. 1436-1444, 2009.

[256] Y. Ran and G. E. Fanucci, "A dansyl fluorescence-based assay for monitoring kinetics of lipid extraction and transfer," Analytical Biochemistry, vol. 382, no. 2, pp. 132-134, 2008.

[257] Y. Ran and G. E. Fanucci, "Ligand extraction properties of the GM2 activator protein and its interactions with lipid vesicles," Biophysical Journal, vol. 97, no. 1, pp. 257-266, 2009.

[258] A. Giehl, T. Lemm, O. Bartelsen, K. Sandhoff, and A. Blume, "Interaction of the GM2-activator protein with phospholipid-ganglioside bilayer membranes and with monolayers at the air-water interface," European Journal of Biochemistry, vol. 261, no. 3, pp. 650-658, 1999.

[259] C. S. Wright, L. Z. Mi, S. Lee, and F. Rastinejad, "Crystal structure analysis of phosphatidylcholine-GM2-activator product complexes: evidence for hydrolase activity," Biochemistry, vol. 44, no. 41, pp. 13510-13521, 2005.

[260] B. Rigat, D. Reynaud, N. Smiljanic-Georgijev, and D. Mahuran, "The GM2 activator protein, a novel inhibitor of platelet-activating factor," Biochemical and Biophysical Research Communications, vol. 258, no. 2, pp. 256-259, 1999.

[261] B. Rigat, H. Yeger, D. Shehnaz, and D. Mahuran, "GM2 activator protein inhibits platelet activating factor signaling in rats," Biochemical and Biophysical Research Communications, vol. 385, no. 4, pp. 576-580, 2009.

[262] C. S. Wright, L. Z. Mi, and F. Rastinejad, "Evidence for lipid packaging in the crystal structure of the GM2-activator complex with platelet activating factor," Journal of Molecular Biology, vol. 342, no. 2, pp. 585-592, 2004.

[263] K. Higashi, H. Kubo, H. Watanabe, K. Fujimori, T. Mikami, and H. Kaneko, "Adipokine ganglioside GM2 activator protein stimulates insulin secretion," FEBS Letters, vol. 585, pp. 2587-2591, 2011.

[264] E. Starostina, A. Xu, H. Lin, and C. W. Pikielny, "A Drosophila protein family implicated in pheromone perception is related to Tay-Sachs GM2-activator protein," The Journal of Biological Chemistry, vol. 284, no. 1, pp. 585-594, 2009.

[265] A. F. Bruce, M. P. Gares, M. E. Selkirk, and K. Gounaris, "Functional characterisation of a nematode secreted GM2activator protein," Molecular and Biochemical Parasitology, vol. 147, no. 2, pp. 224-229, 2006.

[266] L. Leon, R. V. Tatituri, R. Grenha et al., "Saposins utilize two strategies for lipid transfer and CD1 antigen presentation," Proceedings of the National Academy of Sciences of the United States of America, vol. 109, pp. 4357-4364, 2012.

[267] T. Kolter, F. Winau, U. E. Schaible, M. Leippe, and K. Sandhoff, "Lipid-binding proteins in membrane digestion, antigen presentation, and antimicrobial defense," The Journal of Biological Chemistry, vol. 280, no. 50, pp. 41125-41128, 2005.

[268] Y. O. Suzuki A and E. Nanba, " $\beta$-Galactosidase Deficiency ( $\beta$ Galactosidosis): GM1 gangliosidosis and morquio B disease,” 
in The Metabolic and Molecular Bases of Inherited Disease, C. R. Scriver, A. L. Beaudet, W. S. Sly, and D. Valle, Eds., vol. 3, pp. 3775-3809, McGraw-Hill, 2001.

[269] U. Ohto, K. Usui, T. Ochi, K. Yuki, Y. Satow, and T. Shimizu, "Crystal structure of human beta-galactosidase: structural basis of Gm1 gangliosidosis and morquio B diseases," The Journal of Biological Chemistry, vol. 287, pp. 1801-1812, 2012.

[270] A. Hinek, M. Rabinovitch, F. Keeley, Y. Okamura-Oho, and J. Callahan, "The $67-\mathrm{kD}$ elastin/laminin-binding protein is related to an enzymatically inactive, alternatively spliced form of $\beta$-galactosidase," Journal of Clinical Investigation, vol. 91, no. 3, pp. 1198-1205, 1993.

[271] A. D’Azzo and E. Bonten, "Molecular mechanisms of pathogenesis in a glycosphingolipid and a glycoprotein storage disease," Biochemical Society Transactions, vol. 38, no. 6, pp. 1453-1457, 2010.

[272] K. Sango, S. Yamanaka, A. Hoffmann et al., "Mouse models of Tay-Sachs and Sandhoff diseases differ in neurologic phenotype and ganglioside metabolism," Nature Genetics, vol. 11, no. 2, pp. 170-176, 1995.

[273] H. J. Kytzia and K. Sandhoff, "Evidence for two different active sites on human $\beta$-hexosaminidase A. Interaction of G(M2) activator protein with $\beta$-hexosaminidase A," The Journal of Biological Chemistry, vol. 260, no. 12, pp. 7568 7572, 1985.

[274] T. Maier, N. Strater, C. G. Schuette, R. Klingenstein, K. Sandhoff, and W. Saenger, "The X-ray crystal structure of human $\beta$-hexosaminidase B provides new insights into Sandhoff disease," Journal of Molecular Biology, vol. 328, no. 3, pp. 669681, 2003.

[275] B. L. Mark, D. J. Mahuran, M. M. Cherney, D. Zhao, S. Knapp, and M. N. G. James, "Crystal Structure of Human $\beta$-Hexosaminidase B: understanding the Molecular Basis of Sandhoff and Tay-Sachs Disease," Journal of Molecular Biology, vol. 327, no. 5, pp. 1093-1109, 2003.

[276] M. L. Schultz, L. Tecedor, M. Chang, and B. L. Davidson, "Clarifying lysosomal storage diseases," Trends in Neurosciences, vol. 34, no. 8, pp. 401-410, 2011.

[277] Y. H. Xu, S. Barnes, Y. Sun, and G. A. Grabowski, "Multi-system disorders of glycosphingolipid and ganglioside metabolism," Journal of Lipid Research, vol. 51, no. 7, pp. 1643-1675, 2010.

[278] A. Ballabio and V. Gieselmann, "Lysosomal disorders: from storage to cellular damage," Biochimica et Biophysica Acta, vol. 1793, no. 4, pp. 684-696, 2009.

[279] O. Staretz-Chacham, T. C. Lang, M. E. Lamarca, D. Krasnewich, and E. Sidransky, "Lysosomal storage disorders in the newborn," Pediatrics, vol. 123, no. 4, pp. 1191-1207, 2009.

[280] S. U. Walkley and M. T. Vanier, "Secondary lipid accumulation in lysosomal disease," Biochimica et Biophysica Acta, vol. 1793, no. 4, pp. 726-736, 2009.

[281] T. Kolter and K. Sandhoff, "Sphingolipid metabolism diseases," Biochimica et Biophysica Acta, vol. 1758, no. 12, pp. 2057-2079, 2006.

[282] S. U. Walkley, "Pathogenic cascades in lysosomal diseasewhy so complex?" Journal of Inherited Metabolic Disease, vol. 32, no. 2, pp. 181-189, 2009.

[283] T. M. Cox and M. B. Cachon-Gonzalez, "The cellular pathology of lysosomal diseases," The Journal of Pathology, vol. 226, pp. 241-254, 2012.

[284] F. M. Platt and R. H. Lachmann, "Treating lysosomal storage disorders: current practice and future prospects," Biochimica et Biophysica Acta, vol. 1793, no. 4, pp. 737-745, 2009.
[285] P. Leinekugel, S. Michel, E. Conzelmann, and K. Sandhoff, "Quantitative correlation between the residual activity of $\beta$ hexosaminidase A and arylsulfatase A and the severity of the resulting lysosomal storage disease," Human Genetics, vol. 88, no. 5, pp. 513-523, 1992.

[286] E. Conzelmann and K. Sandhoff, "Partial enzyme deficiencies: residual activities and the development of neurological disorders," Developmental Neuroscience, vol. 6, no. 1, pp. 5871, 1983.

[287] M. Zervas, K. Dobrenis, and S. U. Walkley, "Neurons in Niemann-Pick disease type $\mathrm{C}$ accumulate gangliosides as well as unesterified cholesterol and undergo dendritic and axonal alterations," Journal of Neuropathology and Experimental Neurology, vol. 60, no. 1, pp. 49-64, 2001.

[288] M. Zervas, K. L. Somers, M. A. Thrall, and S. U. Walkley, "Critical role for glycosphingolipids in Niemann-Pick disease type C," Current Biology, vol. 11, no. 16, pp. 1283-1287, 2001.

[289] N. H. Pipalia, C. C. Cosner, A. Huang et al., "Histone deacetylase inhibitor treatment dramatically reduces cholesterol accumulation in Niemann-Pick type C1 mutant human fibroblasts," Proceedings of the National Academy of Sciences of the United States of America, vol. 108, no. 14, pp. 5620-5625, 2011.

[290] D. Campos and M. Monaga, "Mucopolysaccharidosis type I: current knowledge on its pathophysiological mechanisms," Metabolic Brain Disease, vol. 27, pp. 121-129, 2012.

[291] M. Aridor and L. A. Hannan, "Tarffic jam: a compendium of human diseases that affect intracellular transport processes," Traffic, vol. 1, no. 11, pp. 836-851, 2000.

[292] M. Aridor and L. A. Hannan, "Traffic Jams II: an update of diseases of intracellular transport," Traffic, vol. 3, no. 11, pp. 781-790, 2002.

[293] M. Jeyakumar, I. Williams, D. A. Smith, T. M. Cox, and F. M. Platt, "Critical role of iron in the pathogenesis of the murine gangliosidoses," Neurobiology of Disease, vol. 34, no. 3, pp. 406-416, 2009.

[294] C. Settembre, A. Fraldi, D. C. Rubinsztein, and A. Ballabio, "Lysosomal storage diseases as disorders of autophagy," Autophagy, vol. 4, no. 1, pp. 113-114, 2008.

[295] N. Brunetti-Pierri and F. Scaglia, "GM1 gangliosidosis: review of clinical, molecular, and therapeutic aspects," Molecular Genetics and Metabolism, vol. 94, no. 4, pp. 391-396, 2008.

[296] J. Caffey, "Gargoylism (Hunter-Hurler disease, dysostosis multiplex, lipochondrodystrophy); prenatal and neonatal bone lesions and their early postnatal evolution," Bulletin of the Hospital for Joint Diseases, vol. 12, no. 2, pp. 38-66, 1951.

[297] B. H. Landing, F. N. Silverman, J. M. Craig, M. D. Jacoby, M. E. Lahey, and D. L. Chadwick, "Familial neurovisceral lipidosis. An analysis of eight cases of a syndrome previously reported as "hurler-variant," "pseudo-hurler," and "tay-sachs disease with visceral involvement"', American Journal of Diseases of Children, vol. 108, pp. 503-522, 1964.

[298] M. Jeyakumar, R. Thomas, E. Elliot-Smith et al., "Central nervous system inflammation is a hallmark of pathogenesis in mouse models of GM1 and GM2 gangliosidosis," Brain, vol. 126, no. 4, pp. 974-987, 2003.

[299] G. Wu, Z. H. Lu, J. Wang et al., "Enhanced susceptibility to kainate-induced seizures, neuronal apoptosis, and death in mice lacking gangliotetraose gangliosides: protection with LIGA 20, a membrane-permeant analog of GM1," Journal of Neuroscience, vol. 25, no. 47, pp. 11014-11022, 2005.

[300] A. Tessitore, M. D. P. Martin, R. Sano et al., "GM1ganglioside-mediated activation of the unfolded protein 
response causes neuronal death in a neurodegenerative gangliosidosis," Molecular Cell, vol. 15, no. 5, pp. 753-766, 2004.

[301] T. Okumiya, H. Sakuraba, R. Kase, and T. Sugiura, "Imbalanced substrate specificity of mutant $\beta$-galactosidase in patients with Morquio B disease," Molecular Genetics and Metabolism, vol. 78, no. 1, pp. 51-58, 2003.

[302] Y. Suzuki, "Chemical chaperone therapy for GM1-gangliosidosis," Cellular and Molecular Life Sciences, vol. 65, no. 3, pp. 351-353, 2008.

[303] A. Caciotti, M. A. Donati, A. d'Azzo et al., "The potential action of galactose as a "chemical chaperone": increase of beta galactosidase activity in fibroblasts from an adult GM1-gangliosidosis patient," European Journal of Paediatric Neurology, vol. 13, no. 2, pp. 160-164, 2009.

[304] B. A. Rigat, M. B. Tropak, J. Buttner et al., "Evaluation of Nnonyl-deoxygalactonojirimycin as a pharmacological chaperone for human GM1 gangliosidosis leads to identification of a feline model suitable for testing enzyme enhancement therapy," Molecular Genetics and Metabolism, vol. 107, no. 12, pp. 203-212, 2012.

[305] R. A. Gravel, M. M. Kaback, R. L. Proia, K. Sandhoff, and K. Suzuki, "The GM2 gangliosidoses," in The Metabolic and Molecular Bases of Inherited Disease, C. R. Scriver, A. L. Beaudet, W. S. Sly, and D. Valle, Eds., vol. 3, pp. 3827-3877, McGraw-Hill, New York, NY, USA, 2001.

[306] H. E. Saqr, D. K. Pearl, and A. J. Yates, "A review and predictive models of ganglioside uptake by biological membranes," Journal of Neurochemistry, vol. 61, no. 2, pp. 395-411, 1993.

[307] G. Schwarzmann, P. Hoffmann-Bleihauer, J. Schubert, K. Sandhoff, and D. Marsh, "Incorporation of ganglioside analogues into fibroblast cell membranes. A spin-label study," Biochemistry, vol. 22, no. 21, pp. 5041-5048, 1983.

[308] C. Eggeling, C. Ringemann, R. Medda et al., "Direct observation of the nanoscale dynamics of membrane lipids in a living cell," Nature, vol. 457, no. 7233, pp. 1159-1162, 2009.

[309] H. J. Kytzia, U. Hinrichs, I. Maire, K. Suzuki, and K. Sandhoff, "Variant of GM2-gangliosidosis with hexosaminidase A having a severely changed substrate specificity," The EMBO Journal, vol. 2, no. 7, pp. 1201-1205, 1983.

[310] K. Suzuki and M. T. Vanier, "Biochemical and molecular aspects of late-onset GM2-gangliosidosis: B1 variant as a prototype," Developmental Neuroscience, vol. 13, no. 4-5, pp. 288-294, 1991.

[311] Y. Ben-Yoseph, J. E. Reid, B. Shapiro, and H. L. Nadler, "Diagnosis and carrier detection of Tay-Sachs disease: direct determination of hexosaminidase A using 4-methylumbelliferyl derivatives of $\beta$-N-acetylglucosamine-6-sulfate and $\beta$-Nacetylgalactosamine-6-sulfate," American Journal of Human Genetics, vol. 37, no. 4, pp. 733-740, 1985.

[312] W. Fuchs, R. Navon, M. M. Kaback, and H. Kresse, "TaySachs disease: one-step assay of $\beta$ - $\mathrm{N}$-acetylhexosaminidase in serum with a sulphated chromogenic substrate," Clinica Chimica Acta, vol. 133, no. 3, pp. 253-261, 1983.

[313] Y. Liu, A. Hoffmann, A. Grinberg et al., "Mouse model of GM2 activator deficiency manifests cerebellar pathology and motor impairment," Proceedings of the National Academy of Sciences of the United States of America, vol. 94, no. 15, pp. 8138-8143, 1997.

[314] D. P. Purpura and K. Suzuki, "Distortion of neuronal geometry and formation of aberrant synapses in neuronal storage disease," Brain Research, vol. 116, no. 1, pp. 1-21, 1976.
[315] S. Neuenhofer, E. Conzelmann, and G. Schwarzmann, "Occurrence of lysoganglioside lyso-G(M2) (II3-neu5Acgangliotriaosylsphingosine) in G(M2) gangliodosis brain," Biological Chemistry Hoppe-Seyler, vol. 367, no. 3, pp. 241244, 1986.

[316] T. Kobayashi, I. Goto, S. Okada, T. Orii, K. Ohno, and T. Nakano, "Accumulation of lysosphingolipids in tissues from patients with GM1 and GM2 gangliosidoses," Journal of Neurochemistry, vol. 59, no. 4, pp. 1452-1458, 1992.

[317] T. Kodama, T. Togawa, T. Tsukimura et al., "Lyso-GM2 ganglioside: a possible biomarker of Tay-Sachs disease and Sandhoff disease," PLoS One, vol. 6, Article ID e29074, 2011.

[318] T. Kolter, "A view on sphingolipids and disease," Chemistry and Physics of Lipids, vol. 164, no. 6, pp. 590-606, 2011.

[319] Y. Liu, R. Wada, H. Kawai et al., "A genetic model of substrate deprivation therapy for a glycosphingolipid storage disorder," Journal of Clinical Investigation, vol. 103, no. 4, pp. 497-505, 1999.

[320] F. Norflus, C. J. Tifft, M. P. McDonald et al., "Bone marrow transplantation prolongs life span and ameliorates neurologic manifestations in Sandhoff disease mice," Journal of Clinical Investigation, vol. 101, no. 9, pp. 1881-1888, 1998.

[321] D. Tsuji, H. Akeboshi, K. Matsuoka et al., "Highly phosphomannosylated enzyme replacement therapy for GM2 gangliosidosis," Annals of Neurology, vol. 69, no. 4, pp. 691701, 2011.

[322] M. Jeyakumar, J. P. Lee, N. R. Sibson et al., "Neural stem cell transplantation benefits a monogenic neurometabolic disorder during the symptomatic phase of disease," Stem Cells, vol. 27, no. 9, pp. 2362-2370, 2009.

[323] M. Masciullo, M. Santoro, A. Modoni et al., "Substrate reduction therapy with miglustat in chronic GM2 gangliosidosis type Sandhoff: results of a 3-year follow-up," Journal of Inherited Metabolic Disease. In press.

[324] F. M. Platt and M. Jeyakumar, "Substrate reduction therapy," Acta Paediatrica, vol. 97, no. 457, pp. 88-93, 2008.

[325] J. T. R. Clarke, D. J. Mahuran, S. Sathe et al., "An open-label Phase I/II clinical trial of pyrimethamine for the treatment of patients affected with chronic GM2 gangliosidosis (Tay-Sachs or Sandhoff variants)," Molecular Genetics and Metabolism, vol. 102, no. 1, pp. 6-12, 2011.

[326] K. S. Bateman, M. M. Cherney, D. J. Mahuran, M. Tropak, and M. N. G. James, "Crystal structure of $\beta$-hexosaminidase $\mathrm{B}$ in complex with pyrimethamine, a potential pharmacological chaperone," Journal of Medicinal Chemistry, vol. 54, no. 5, pp. 1421-1429, 2011.

[327] L. Batista, F. Miller, C. Clave et al., "Induced secretion of $\beta$-hexosaminidase by human brain endothelial cells: a novel approach in Sandhoff disease?" Neurobiology of Disease, vol. 37, no. 3, pp. 656-660, 2010.

[328] M. Jeyakumar, D. A. Smith, I. M. Williams et al., "NSAIDs increase survival in the Sandhoff disease mouse: synergy with N-butyldeoxynojirimycin," Annals of Neurology, vol. 56, no. 5, pp. 642-649, 2004.

[329] K. Yanagisawa, "Pathological significance of ganglioside clusters in Alzheimer's disease," Journal of Neurochemistry, vol. 116, no. 5, pp. 806-812, 2011.

[330] R. K. Yu, Y. T. Tsai, and T. Ariga, "Functional roles of gangliosides in neurodevelopment: an overview of recent advances," Neurochemical Research, vol. 37, pp. 1230-1244, 2012.

[331] A. Prinetti, S. Prioni, N. Loberto et al., "Aberrant glycosphingolipid expression and membrane organization in tumor cells: consequences on tumor-host interactions," Advances in 
Experimental Medicine and Biology, vol. 705, pp. 643-667, 2011.

[332] D. F. Alonso, L. E. Fernandez, M. R. Gabri et al., "NGcGM3 ganglioside: a privileged target for cancer vaccines," Clinical and Developmental Immunology, vol. 2010, Article ID 814397, 8 pages, 2010.

[333] J. Heimburg-Molinaro, M. Lum, G. Vijay, M. Jain, A. Almogren, and K. Rittenhouse-Olson, "Cancer vaccines and carbohydrate epitopes," Vaccine, vol. 29, pp. 8802-8826, 2011.

[334] L. G. Durrant, P. Noble, and I. Spendlove, "Immunology in the clinic review series, focus on cancer: glycolipids as targets for tumour immunotherapy," Clinical \& Experimental Immunology, vol. 167, pp. 206-215, 2012.

[335] A. Uncini, "A common mechanism and a new categorization for anti-ganglioside antibody-mediated neuropathies," Experimental Neurology, vol. 235, pp. 513-516, 2012.

[336] J. S. Schneider, "The therapeutic role of gangliosides in neurological disorders," CNS Drugs, vol. 1, pp. 213-222, 1994.

[337] A. C. Cuello, "Gangliosides, NGF, brain aging and disease: a mini-review with personal reflections," Neurochemical Research, vol. 37, pp. 1256-1260, 2012.

[338] L. Svennerholm, G. Bråne, I. Karlsson, A. Lekman, I. Ramström, and C. Wikkelsö, "Alzheimer disease-effect of continuous intracerebroventricular treatment with GM1 ganglioside and a systematic activation programme," Dementia and Geriatric Cognitive Disorders, vol. 14, no. 3, pp. 128136, 2002.

[339] J. I. Inokuchi, "Inhibition of ganglioside biosynthesis as a novel therapeutic approach in insulin resistance," Handbook of Experimental Pharmacology, vol. 203, pp. 165-178, 2011.

[340] R. J. Thomas, "Receptor mimicry as novel therapeutic treatment for biothreat agents," Bioengineered Bugs, vol. 1, no. 1, pp. 17-30, 2010.

[341] A. Bachis and I. Mocchetti, "Semisynthetic sphingoglycolipid LIGA20 is neuroprotective against human immunodeficiency virus-gp120-mediated apoptosis," Journal of Neuroscience Research, vol. 83, no. 5, pp. 890-896, 2006.

[342] C. B. Zeller and R. B. Marchase, "Gangliosides as modulators of cell function," American Journal of Physiology, vol. 262, no. 6, pp. C1341-C1355, 1992.

[343] N. V. Prokazova, N. N. Samovilova, E. V. Gracheva, and N. K. Golovanova, "Ganglioside GM3 and its biological functions," Biochemistry, vol. 74, no. 3, pp. 235-249, 2009.

[344] R. W. Ledeen and G. Wu, "In search of a solution to the sphinx-like riddle of GM1," Neurochemical Research, vol. 35, no. 12, pp. 1867-1874, 2010.

[345] A. Regina Todeschini and S. I. Hakomori, "Functional role of glycosphingolipids and gangliosides in control of cell adhesion, motility, and growth, through glycosynaptic microdomains," Biochimica et Biophysica Acta, vol. 1780, no. 3, pp. 421-433, 2008.

[346] S. I. Hakomori, "Glycosynaptic microdomains controlling tumor cell phenotype through alteration of cell growth, adhesion, and motility," FEBS Letters, vol. 584, no. 9, pp. 1901-1906, 2010.

[347] P. H. Lopez and R. L. Schnaar, "Gangliosides in cell recognition and membrane protein regulation," Current Opinion in Structural Biology, vol. 19, no. 5, pp. 549-557, 2009.

[348] R. L. Schnaar, "Glycolipid-mediated cell-cell recognition in inflammation and nerve regeneration," Archives of Biochemistry and Biophysics, vol. 426, no. 2, pp. 163-172, 2004.

[349] R. W. Ledeen, G. S. Wu, S. Andre et al., "Beyond glycoproteins as galectin counterreceptors: tumor-effector $\mathrm{T}$ cell growth control via ganglioside GM1," Annals of the New York Academy of Sciences, vol. 1253, pp. 206-221, 2012.

[350] J. Kopitz, C. Von Reitzenstein, M. Burchert, M. Cantz, and H. J. Gabius, "Galectin-1 is a major receptor for ganglioside GM1, a product of the growth-controlling activity of a cell surface ganglioside sialidase, on human neuroblastoma cells in culture," The Journal of Biological Chemistry, vol. 273, no. 18, pp. 11205-11211, 1998.

[351] S. Hakomori, "Carbohydrate-to-carbohydrate interaction, through glycosynapse, as a basis of cell recognition and membrane organization," Glycoconjugate Journal, vol. 21, no. 3-4, pp. 125-137, 2004.

[352] S. Hakomori, "Carbohydrate-Carbohydrate interaction in basic cell biology," in Comprehensive Glycoscience, J. P. Kamerling, G. J. Boons, Y. C. Lee, A. Suzuki, N. Taniguchi, and A. G. J. Voragen, Eds., vol. 3, pp. 787-803, Elsevier, Oxford, UK, 2007.

[353] I. Bucior and M. M. Burger, "Carbohydrate-carbohydrate interactions in cell recognition," Current Opinion in Structural Biology, vol. 14, no. 5, pp. 631-637, 2004.

[354] N. Kojima and S. Hakomori, "Specific interaction between gangliotriaosylceramide $(\mathrm{Gg} 3)$ and sialosyllactosylceramide (G(M3) as a basis for specific cellular recognition between lymphoma and melanoma cells," The Journal of Biological Chemistry, vol. 264, no. 34, pp. 20159-20162, 1989.

[355] R. L. Schnaar, "Brain gangliosides in axon-myelin stability and axon regeneration," FEBS Letters, vol. 584, no. 9, pp. 1741-1747, 2010.

[356] L. Cantu, E. Del Favero, S. Sonnino, and A. Prinetti, "Gangliosides and the multiscale modulation of membrane structure," Chemistry and Physics of Lipids, vol. 164, pp. 796810, 2011.

[357] J. Inokuchi and K. Kabayama, "Receptor modifications in glycobiology," in Comprehensive Glycoscience, J. P. Kamerling, G. J. Boons, Y. C. Lee, A. Suzuki, N. Taniguchi, and A. G. J. Voragen, Eds., vol. 3, pp. 733-743, Elsevier, Oxford, UK, 2007.

[358] R. L. Schnaar, "Neural functions of glycolipids," in Comprehensive Glycoscience, J. P. Kamerling, G. J. Boons, Y. C. Lee, A. Suzuki, N. Taniguchi, and A. G. J. Voragen, Eds., vol. 4, pp. 323-337, Elsevier, Oxford, UK, 2007.

[359] C. L. Schengrund, "Lipid rafts: keys to neurodegeneration," Brain Research Bulletin, vol. 82, no. 1-2, pp. 7-17, 2010.

[360] U. Coskun, M. Grzybek, D. Drechsel, and K. Simons, "Regulation of human EGF receptor by lipids," Proceedings of the National Academy of Sciences of the United States of America, vol. 108, no. 22, pp. 9044-9048, 2011.

[361] S. Sonnino, L. Mauri, V. Chigorno, and A. Prinetti, "Gangliosides as components of lipid membrane domains," Glycobiology, vol. 17, no. 1, pp. 1r-13r, 2007.

[362] K. Simons and J. L. Sampaio, "Membrane organization and lipid rafts," Cold Spring Harbor Perspectives in Biology, vol. 3, Article ID a004697, 2011.

[363] K. Simons and M. J. Gerl, "Revitalizing membrane rafts: new tools and insights," Nature Reviews Molecular Cell Biology, vol. 11, no. 10, pp. 688-699, 2010.

[364] D. Lingwood and K. Simons, "Lipid rafts as a membraneorganizing principle," Science, vol. 327, no. 5961, pp. 46-50, 2010.

[365] J. Lippincott-Schwartz and R. D. Phair, "Lipids and cholesterol as regulators of traffic in the endomembrane system," Annual Review of Biophysics, vol. 39, no. 1, pp. 559-578, 2010.

[366] H. D. Gallala and K. Sandhoff, "Principles of microdomain formation in biological membranes-are there lipid liquid 
ordered domains in living cellular membranes?" Trends in Glycoscience and Glycotechnology, vol. 20, no. 116, pp. 277295, 2008.

[367] J. Van Rheenen, E. M. Achame, H. Janssen, J. Calafat, and K. Jalink, "PIP2 signaling in lipid domains: a critical reevaluation,” The EMBO Journal, vol. 24, no. 9, pp. 1664-1673, 2005.

[368] L. J. Pike, "Rafts defined: a report on the keystone symposium on lipid rafts and cell function," Journal of Lipid Research, vol. 47, no. 7, pp. 1597-1598, 2006.

[369] D. Lichtenberg, F. M. Goñi, and H. Heerklotz, "Detergentresistant membranes should not be identified with membrane rafts," Trends in Biochemical Sciences, vol. 30, no. 8, pp. 430-436, 2005.

[370] H. Heerklotz, "Triton promotes domain formation in lipid raft mixtures," Biophysical Journal, vol. 83, no. 5, pp. 2693 2701, 2002.

[371] M. Heffer-Lauc, G. Lauc, L. Nimrichter, S. E. Fromholt, and R. L. Schnaar, "Membrane redistribution of gangliosides and glycosylphosphatidylinositol-anchored proteins in brain tissue sections under conditions of lipid raft isolation," Biochimica et Biophysica Acta, vol. 1686, no. 3, pp. 200-208, 2005.

[372] M. Heffer-Lauc, G. Lauc, L. Nimrichter, S. E. Fromholt, and R. L. Schnaar, "Membrane redistribution of gangliosides and glycosylphosphatidylinositol-anchored proteins in brain tissue sections under conditions of lipid raft isolation," Biochimica et Biophysica Acta, vol. 1686, no. 3, pp. 200-208, 2005.

[373] M. Brameshuber, J. Weghuber, V. Ruprecht et al., "Imaging of mobile long-lived nanoplatforms in the live cell plasma membrane," The Journal of Biological Chemistry, vol. 285, no. 53, pp. 41765-41771, 2010.

[374] T. Janas, "Membrane oligo- and polysialic acids," Biochimica et Biophysica Acta, vol. 1808, pp. 2923-2932, 2011.

[375] B. C. Salazar, S. Castaño, J. C. Sãnchez, M. Romero, and E. Recio-Pinto, "Ganglioside GDla increases the excitability of voltage-dependent sodium channels," Brain Research, vol. 1021, no. 2, pp. 151-158, 2004.

[376] A. Varki and P. Gagneux, "Multifarious roles of sialic acids in immunity," Annals of the New York Academy of Sciences, vol. 1253, pp. 16-36, 2012.

[377] K. Hanada, "Sphingolipids in infectious diseases," Japanese Journal of Infectious Diseases, vol. 58, no. 3, pp. 131-148, 2005.

[378] U. Neu, J. Bauer, and T. Stehle, "Viruses and sialic acids: rules of engagement," Current Opinion in Structural Biology, vol. 21, pp. 610-618, 2011.

[379] J. Sánchez and J. Holmgren, "Cholera toxin-a foe \& a friend," Indian Journal of Medical Research, vol. 133, no. 2, pp. 153-163, 2011.

[380] N. Roche, J. Ångström, M. Hurtig, T. Larsson, T. Borén, and S. Teneberg, "Helicobacter pylori and complex gangliosides," Infection and Immunity, vol. 72, no. 3, pp. 1519-1529, 2004.

[381] A. Varki, "Sialic acids in human health and disease," Trends in Molecular Medicine, vol. 14, no. 8, pp. 351-360, 2008.

[382] P. R. Crocker, J. C. Paulson, and A. Varki, "Siglecs and their roles in the immune system," Nature Reviews Immunology, vol. 7, no. 4, pp. 255-266, 2007.

[383] J. C. Paulson, M. S. Macauley, and N. Kawasaki, "Siglecs as sensors of self in innate and adaptive immune responses," Annals of the New York Academy of Sciences, vol. 1253, pp. $37-48,2012$.
[384] G. Stafford, S. Roy, K. Honma, and A. Sharma, "Sialic acid, periodontal pathogens and Tannerella forsythia: stick around and enjoy the feast!," Molecular Oral Microbiology, vol. 27, pp. 11-22, 2012.

[385] K. D. Erickson, R. L. Garcea, and B. Tsai, "Ganglioside GT1b is a putative host cell receptor for the Merkel cell polyomavirus," Journal of Virology, vol. 83, no. 19, pp. 1027510279, 2009.

[386] T. Haselhorst, F. E. Fleming, J. C. Dyason et al., "Sialic acid dependence in rotavirus host cell invasion," Nature Chemical Biology, vol. 5, no. 2, pp. 91-93, 2009.

[387] E. C. Nilsson, R. J. Storm, J. Bauer et al., "The GDla glycan is a cellular receptor for adenoviruses causing epidemic keratoconjunctivitis," Nature Medicine, vol. 17, no. 1, pp. 105-109, 2011.

[388] K. Furukawa, O. Tajima, T. Okuda, N. Tokuda, and K. Furukawa, "Knockout mice and glycolipids," in Comprehensive Glycoscience, J. P. Kamerling, G. J. Boons, Y. C. Lee, A. Suzuki, N. Taniguchi, and A. G. J. Voragen, Eds., vol. 4, pp. 149-157, Elsevier, Oxford, UK, 2007.

[389] G. Wu, X. Xie, Z. H. Lu, and R. W. Ledeen, "Cerebellar neurons lacking complex gangliosides degenerate in the presence of depolarizing levels of potassium," Proceedings of the National Academy of Sciences of the United States of America, vol. 98, no. 1, pp. 307-312, 2001.

[390] K. Furukawa, Y. Ohmi, Y. Ohkawa et al., "Regulatory mechanisms of nervous systems with glycosphingolipids," Neurochemical Research, vol. 36, pp. 1578-1586, 2011.

[391] F. Sabourdy, B. Kedjouar, S. C. Sorli et al., "Functions of sphingolipid metabolism in mammals - Lessons from genetic defects," Biochimica et Biophysica Acta, vol. 1781, no. 4, pp. 145-183, 2008.

[392] R. P. Rao and J. K. Acharya, "Sphingolipids and membrane biology as determined from genetic models," Prostaglandins and Other Lipid Mediators, vol. 85, no. 1-2, pp. 1-16, 2008.

[393] S. Matuoka, M. Akiyama, H. Yamada, K. Tsuchihashi, and S. Gasa, "Phase behavior in multilamellar vesicles of DPPC containing ganglioside GM3 with a C18:1 sphingoid base and a 24:0 acyl chain $(\mathrm{GM} 3(18,24))$ observed by X-ray diffraction," Chemistry and Physics of Lipids, vol. 123, no. 1, pp. 19-29, 2003.

[394] T. Wennekes, R. J. B. H. N. Van Den Berg, R. G. Boot, G. A. Van Der Marel, H. S. Overkleeft, and J. M. F. G. Aerts, "Glycosphingolipids-nature, function, and pharmacological modulation," Angewandte Chemie, vol. 48, no. 47, pp. 8848-8869, 2009.

[395] H. Shibuya, K. Hamamura, H. Hotta et al., "Enhancement of malignant properties of human osteosarcoma cells with disialyl gangliosides GD2/GD32012," Cancer Science, vol. 103, no. 9, pp. 1656-1664.

[396] Y. Dong, K. Ikeda, K. Hamamura et al., "GM1/GD1/GA1 synthase expression results in the reduced cancer phenotypes with modulation of composition and raft-localization of gangliosides in a melanoma cell line," Cancer Science, vol. 101, no. 9, pp. 2039-2047, 2010.

[397] J. I. Inokuchi, "Chapter 22 neurotrophic and neuroprotective actions of an enhancer of ganglioside biosynthesis," International Review of Neurobiology, vol. 85, pp. 319-336, 2009.

[398] G. Wu, Z. H. Lu, X. Xie, B. Li, and R. W. Ledeen, "Mutant NG108-15 cells (NG-CR72) deficient in GM1 synthase respond aberrantly to axonogenic stimuli and are vulnerable to calcium-induced apoptosis: they are rescued with LIGA20," Journal of Neurochemistry, vol. 76, no. 3, pp. 690-702, 2001. 
[399] T. Kolter, T. M. Magin, and K. Sandhoff, "Biomolecule function: no reliable prediction from cell culture," Traffic, vol. 1, no. 10, pp. 803-804, 2000.

[400] M. R. Bond, H. Zhang, J. Kim et al., "Metabolism of diazirine-modified $\mathrm{N}$-acetylmannosamine analogues to photocross-linking sialosides," Bioconjugate Chemistry, vol. 22, pp. 1811-1823, 2011.

[401] H. Kayser, R. Zeitler, C. Kannicht, D. Grunow, R. Nuck, and W. Reutter, "Biosynthesis of a nonphysiological sialic acid in different rat organs, using N-propanoyl-D-hexosamines as precursors," The Journal of Biological Chemistry, vol. 267, no. 24, pp. 16934-16938, 1992.

[402] P. Palestini, M. Pitto, G. Tedeschi et al., "Tubulin anchoring to glycolipid-enriched, detergent-resistant domains of the neuronal plasma membrane," The Journal of Biological Chemistry, vol. 275, no. 14, pp. 9978-9985, 2000.

[403] M. Panasiewicz, J. Mieczkowski, H. Domek, and T. Pacuszka, "HPLC-based procedure for the preparation of carbenegenerating photoreactive GM3 and GM1 ganglioside derivatives radioiodinated to high specific radioactivity with chloramine T as an oxidant," Analytical Biochemistry, vol. 340, no. 2, pp. 373-375, 2005.

[404] P. Zimmermann, R. Bommer, T. Bar, and R. R. Schmidt, "Azidosphingosine glycosylation in glycosphingolipid synthesis," Journal of Carbohydrate Chemistry, vol. 7, no. 2, pp. 435-452, 1988.

[405] R. R. Schmid and X. Zhu, "Glycosyl trichloroacetimidates," in Glycoscience, B. O. Fraser-Reid, K. Tatsuta, and J. Thiem, Eds., pp. 452-542, Springer, Berlin, Germany, 2008.

[406] H. Ando and M. Kiso, "Selective $\alpha$-Sialylation," in Glycoscience, B. O. Fraser-Reid, K. Tatsuta, and J. Thiem, Eds., pp. 1315-1359, Springer, Berlin, Germany, 2008.

[407] H. A. Chokhawala and X. Chen, "Enzymatic approaches to O-glycoside introduction: glycosyltransferases," in Comprehensive Glycoscience, J. P. Kamerling, G. J. Boons, Y. C. Lee, A. Suzuki, N. Taniguchi, and A. G. J. Voragen, Eds., vol. 1, pp. 415-451, Elsevier, Oxford, UK, 2007.

[408] O. Blixt and N. Razi, "Enzymatic glycosylation by transferases," in Glycoscience, B. O. Fraser-Reid, K. Tatsuta, and J. Thiem, Eds., pp. 1362-1385, Springer, Berlin, Germany, 2008.

[409] J. R. Rich, A. M. Cunningham, M. Gilbert, and S. G. Withers, "Glycosphingolipid synthesis employing a combination of recombinant glycosyltransferases and an endoglycoceramidase glycosynthase," Chemical Communications, vol. 47, pp. 10806-10808, 2011.

[410] S. Fort, L. Birikaki, M. P. Dubois, T. Antoine, E. Samain, and H. Driguez, "Biosynthesis of conjugatable saccharidic moieties of GM2 and GM3 gangliosides by engineered E. coli," Chemical Communications, no. 20, pp. 2558-2560, 2005.

[411] M. Gilbert, M. F. Karwaski, S. Bernatchez et al., "The genetic bases for the variation in the lipo-oligosaccharide of the mucosal pathogen, Campylobacter jejuni. Biosynthesis of sialylated ganglioside mimics in the core oligosaccharide," The Journal of Biological Chemistry, vol. 277, no. 1, pp. 327337, 2002.

[412] N. Fierfort and E. Samain, "Genetic engineering of Escherichia coli for the economical production of sialylated oligosaccharides," Journal of Biotechnology, vol. 134, no. 3-4, pp. 261-265, 2008.

[413] T. Antoine, A. Heyraud, C. Bosso, and E. Samain, "Highly efficient biosynthesis of the oligosaccharide moiety of the GD3 ganglioside by using metabolically engineered
Escherichia coli," Angewandte Chemie, vol. 44, no. 9, pp. 13501352, 2005

[414] B. Priem, M. Gilbert, W. W. Wakarchuk, A. Heyraud, and E. Samain, "A new fermentation process allows large-scale production of human milk oligosaccharides by metabolically engineered bacteria," Glycobiology, vol. 12, no. 4, pp. 235240, 2002.

[415] T. Antoine, B. Priem, A. Heyraud et al., "Large-scale in vivo synthesis of the carbohydrate moieties of gangliosides GM1 and GM2 by metabolically engineered Escherichia coli," ChemBioChem, vol. 4, no. 5, pp. 406-412, 2003.

[416] Y. Shimura, J. Suzuki, M. Muraoka, M. C. Kasuya, K. Matsuoka, and K. Hatanaka, "Large scale biosynthesis of ganglioside analogues by RERF-LC-AI cells cultured in HYPERFlask," Preparative Biochemistry and Biotechnology, vol. 42, pp. 378-392, 2012.

[417] R. Ghidoni, G. Sala, and A. Giuliani, "Use of sphingolipid analogs: benefits and risks," Biochimica et Biophysica Acta, vol. 1439, no. 1, pp. 17-39, 1999.

[418] G. Schwarzmann, "A simple and novel method for tritium labeling of gangliosides and other sphingolipids," Biochimica et Biophysica Acta, vol. 529, no. 1, pp. 106-114, 1978.

[419] S. Sonnino, M. Nicolini, and V. Chigorno, "Preparation of radiolabeled gangliosides," Glycobiology, vol. 6, no. 5, pp. 479-487, 1996.

[420] G. Schwarzmann, "Uptake and metabolism of exogenous glycosphingolipids by cultured cells," Seminars in Cell and Developmental Biology, vol. 12, no. 2, pp. 163-171, 2001.

[421] S. I. Hakomori, "Structure and function of glycosphingolipids and sphingolipids: recollections and future trends," Biochimica et Biophysica Acta, vol. 1780, no. 3, pp. 325-346, 2008.

[422] S. I. Hakomori, "Release of carbohydrates from sphingoglycolipid by osmium-catalyzed periodate oxidation followed by treatment with mild alkali," Journal of Lipid Research, vol. 7, no. 6, pp. 789-792, 1966.

[423] H. Wiegandt and H. W. Bücking, "Carbohydrate components of extraneuronal gangliosides from bovine and human spleen, and bovine kidney," European Journal of Biochemistry, vol. 15, no. 2, pp. 287-292, 1970.

[424] N. Nagahori, M. Abe, and S. I. Nishimura, "Structural and functional glycosphingolipidomics by glycoblotting with an aminooxy-functionalized gold nanoparticle," Biochemistry, vol. 48, no. 3, pp. 583-594, 2009.

[425] S. C. Li, R. Degasperi, J. E. Muldrey, and Y. T. Li, "A unique glycosphingolipid-splitting enzyme (ceramide-glycanase from leech) cleaves the linkage between the oligosaccharide and the ceramide," Biochemical and Biophysical Research Communications, vol. 141, no. 1, pp. 346-352, 1986.

[426] Y. T. Li, C. W. Chou, S. C. Li, U. Kobayashi, Y. H. Ishibashi, and M. Ito, "Preparation of homogenous oligosaccharide chains from glycosphingolipids," Glycoconjugate Journal, vol. 26, no. 8, pp. 929-933, 2009.

[427] S. Neuenhofer, G. Schwarzmann, H. Egge, and K. Sandhoff, "Synthesis of lysogangliosides," Biochemistry, vol. 24, no. 2, pp. 525-532, 1985.

[428] G. Schwarzmann and K. Sandhoff, "Lysogangliosides: synthesis and use in preparing labeled gangliosides," Methods in Enzymology, vol. 138, pp. 319-341, 1987.

[429] T. Ando, S. C. Li, M. Ito, and Y. T. Li, "Facile method for the preparation of lyso-GM1 and lyso-GM2," Journal of Chromatography A, vol. 1078, no. 1-2, pp. 193-195, 2005. 
[430] E. Arigi, O. Blixt, K. Buschard, H. Clausen, and S. B. Levery, "Design of a covalently bonded glycosphingolipid microarray,” Glycoconjugate Journal, vol. 29, pp. 1-12, 2012.

[431] Y. Tagawa, W. Laroy, L. Nimrichter et al., "Anti-ganglioside antibodies bind with enhanced affinity to gangliosides containing very long chain fatty acids," Neurochemical Research, vol. 27, no. 7-8, pp. 847-855, 2002.

[432] F. Knoll, T. Kolter, and K. Sandhoff, "Sphingolipid photoaffinity labels," Methods in Enzymology, vol. 311, pp. 568600, 1999.

[433] B. Maggio, J. Albert, and R. K. Yu, "Thermodynamicgeometric correlations for the morphology of self-assembled structures of glycosphingolipids and their mixtures with dipalmitoylphosphatidylcholine," Biochimica et Biophysica Acta, vol. 945, no. 2, pp. 145-160, 1988.

[434] S. Sonnino, L. Cantù, M. Corti, D. Acquotti, and B. Venerando, "Aggregative properties of gangliosides in solution," Chemistry and Physics of Lipids, vol. 71, no. 1, pp. 2145, 1994.

[435] A. Prinetti, L. Mauri, V. Chigorno, and S. Sonnino, "Lipid membrane domains in glycobiology," in Comprehensive Glycoscience, J. P. Kamerling, G. J. Boons, Y. C. Lee, A. Suzuki, N. Taniguchi, and A. G. J. Voragen, Eds., vol. 3, pp. 697-730, Elsevier, Oxford, UK, 2007.

[436] B. Ulrich-Bott and H. Wiegandt, "Micellar properties of glycosphingolipids in aqueous media," Journal of Lipid Research, vol. 25, no. 11, pp. 1233-1245, 1984.

[437] G. Lauc and M. Heffer-Lauc, "Shedding and uptake of gangliosides and glycosylphosphatidylinositol-anchored proteins," Biochimica et Biophysica Acta, vol. 1760, no. 4, pp. 584602, 2006.

[438] R. Callies, G. Schwarzmann, and K. Radsak, "Characterization of the cellular binding of exogenous gangliosides," European Journal of Biochemistry, vol. 80, no. 2, pp. 425-432, 1977.

[439] J. A. M. Rasmussen and A. Hermetter, "Chemical synthesis of fluorescent glycero- and sphingolipids," Progress in Lipid Research, vol. 47, no. 6, pp. 436-460, 2008.

[440] R. Olshefski and S. Ladisch, "Synthesis, shedding, and intercellular transfer of human medulloblastoma gangliosides: abrogation by a new inhibitor of glucosylceramide synthase," Journal of Neurochemistry, vol. 70, no. 2, pp. 467-472, 1998.

[441] S. Ladisch, B. Gillard, C. Wong, and L. Ulsh, "Shedding and immunoregulatory activity of YAC-1 lymphoma cell gangliosides," Cancer Research, vol. 43, no. 8, pp. 3808-3813, 1983.

[442] R. Li and S. Ladisch, "Shedding of human neuroblastoma gangliosides," Biochimica et Biophysica Acta, vol. 1083, no. 1, pp. 57-64, 1991.

[443] G. Schwarzmann, M. Wendeler, and K. Sandhoff, "Synthesis of novel NBD-GM1 and NBD-GM2 for the transfer activity of GM2-activator protein by a FRET-based assay system," Glycobiology, vol. 15, no. 12, pp. 1302-1311, 2005. 

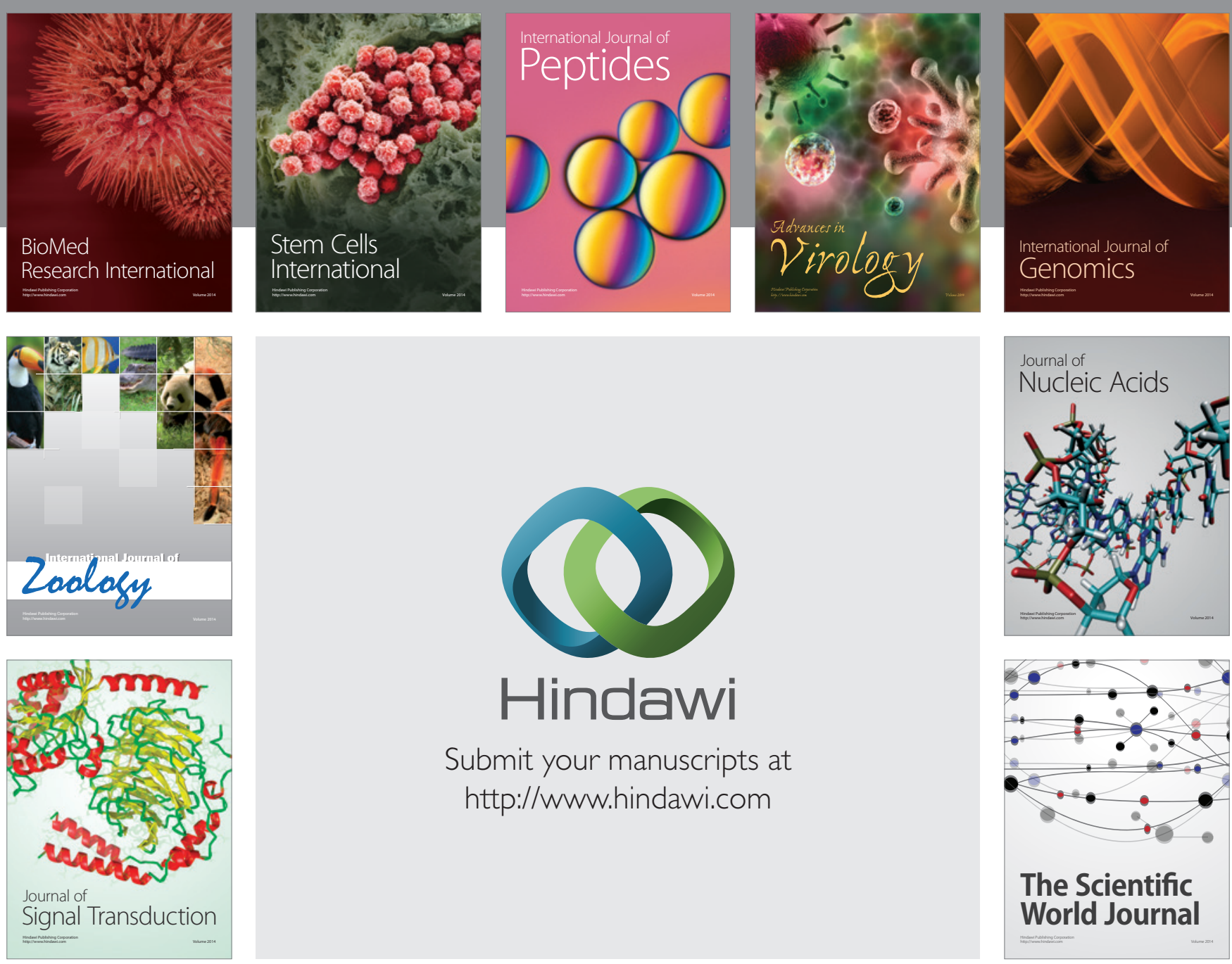

Submit your manuscripts at

http://www.hindawi.com
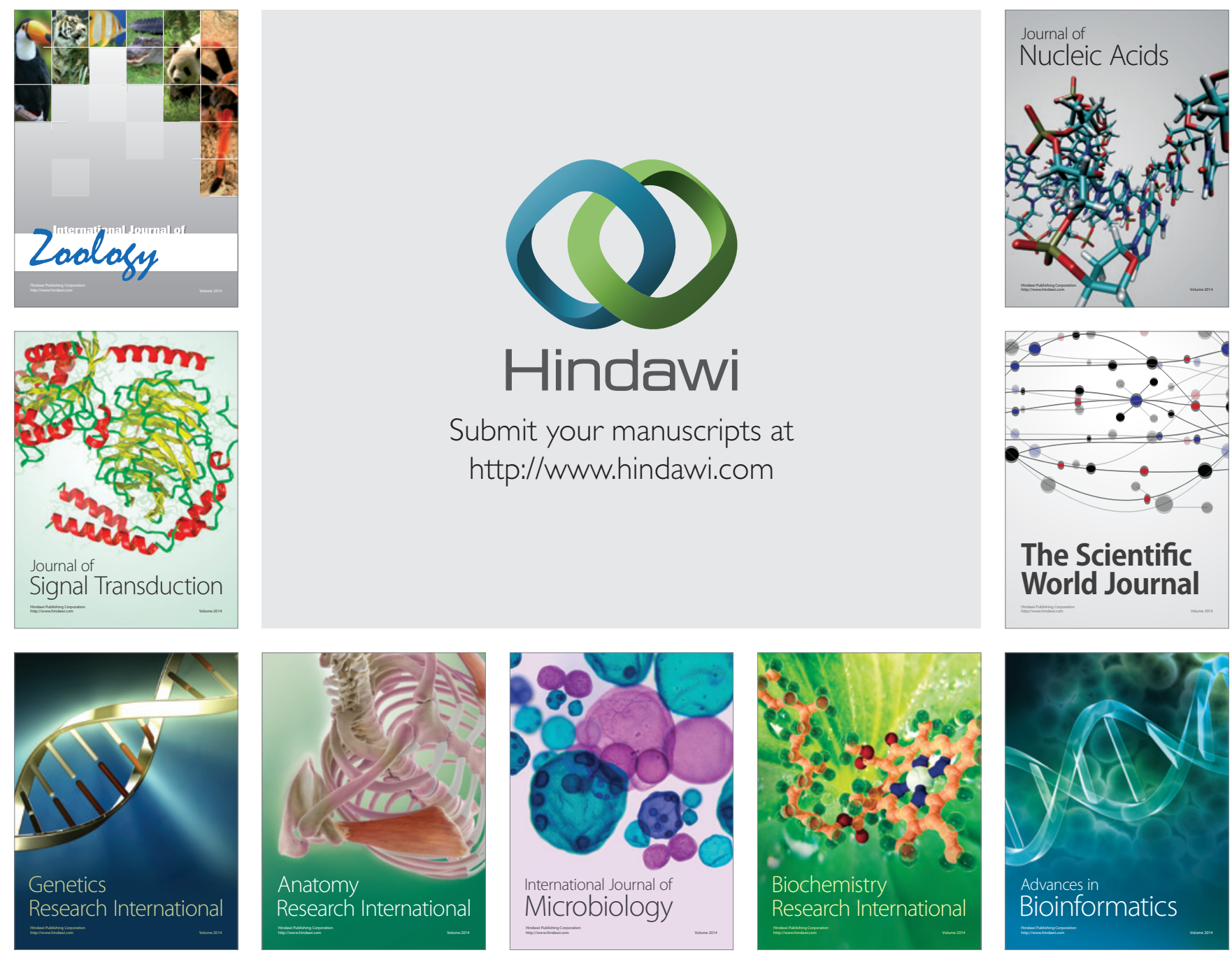

The Scientific World Journal
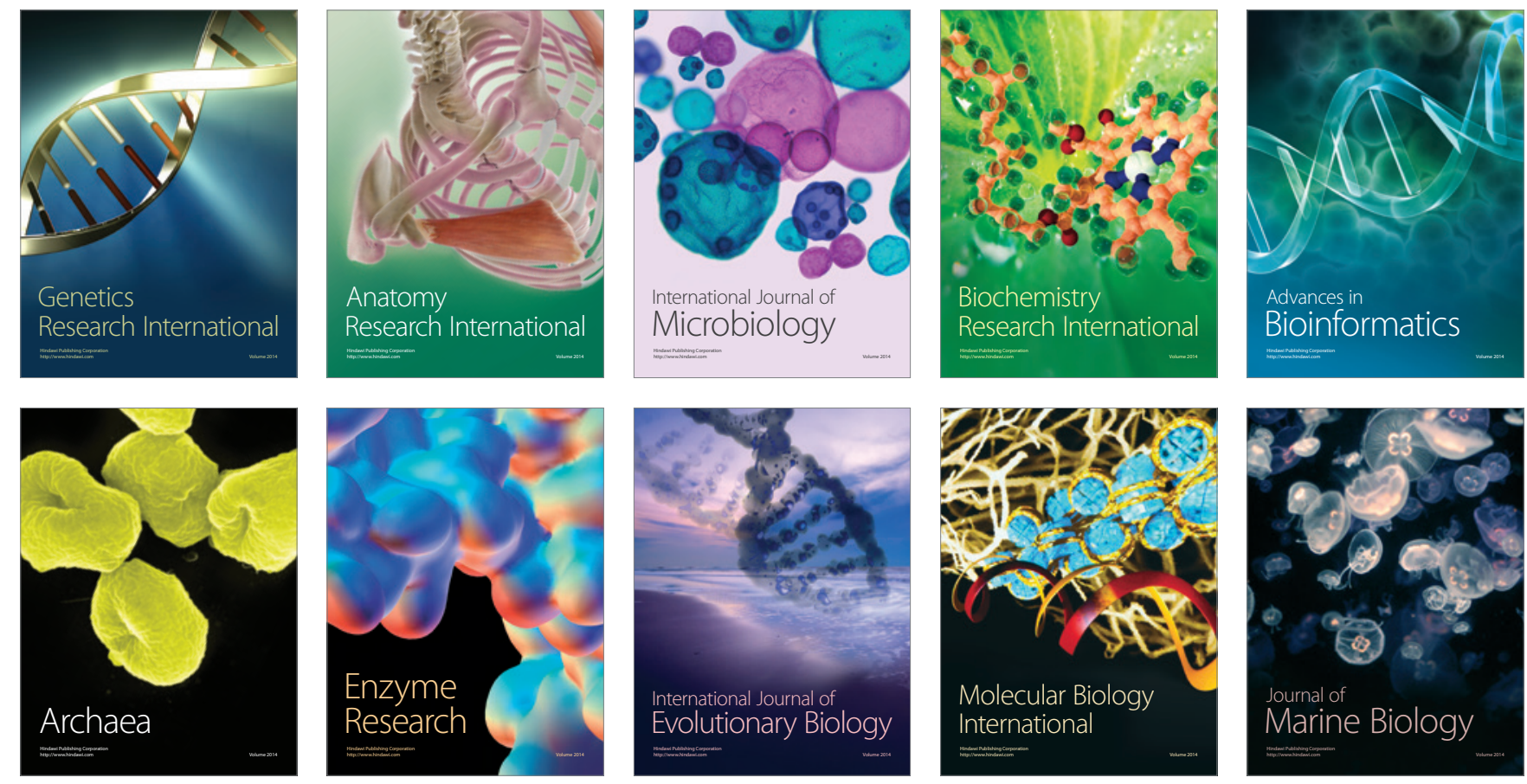